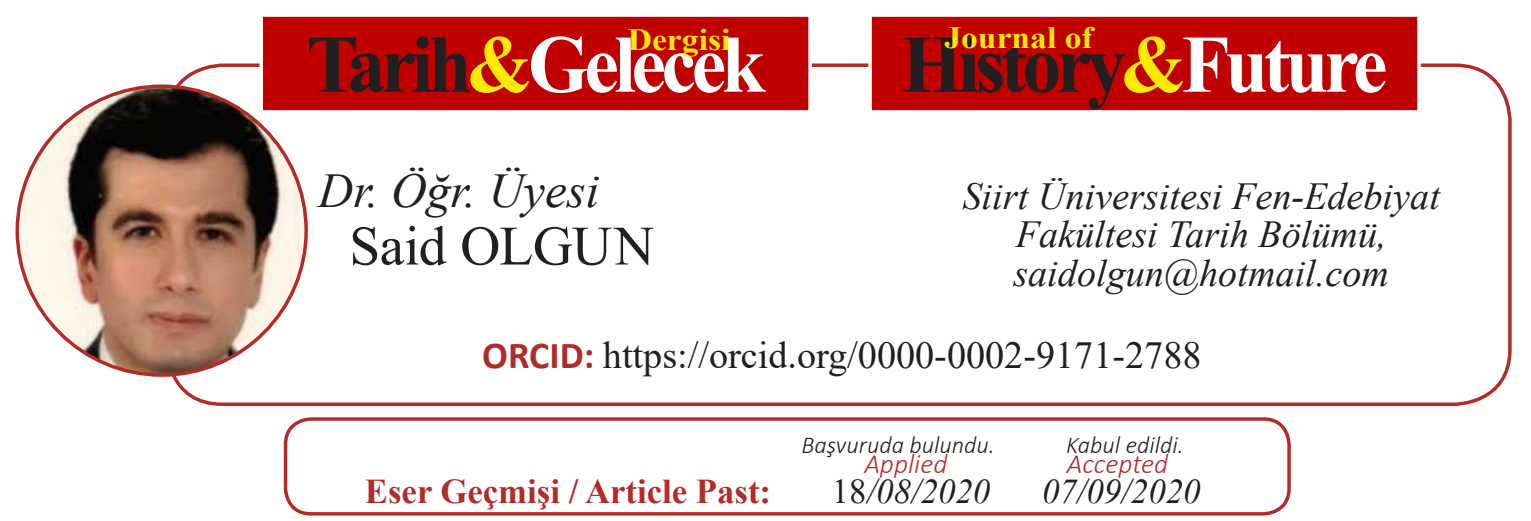

Araştırma Makalesi

DOI: http://dx.doi.org/10.21551/jhf.781937

Research Paper

Orjinal Makale / Orginal Paper

\title{
Kosova Arnavutlarının Millî Kahramanı İsa Bolatinî (1864-1916)
}

\author{
National Hero of Kosovo Albanians İsa Bolatinî (1864-1916)
}

\section{Öz}

İsa Bolatinî hem yaşadığı coğrafya ve dönem hem de kurduğu ağlar ile Osmanlı Devleti'nin son döneminde Rumeli'de meydana gelen birçok önemli olayda yer almıştır. İsminin geçtiği ilk devlet yazışmalarında ondan bir eşkıya olarak bahsedilirken, yaşadığı bölgedeki Müslüman ve Hıristiyan halka yaptığı zulümler dile getiriliyordu. Zamanla bölgede varlık göstermek isteyen Rusya'nın Mitroviçe'de bir konsolosluk kurmasının önündeki en büyük engel olarak görülen İsa, diplomatik görüşmelerin önemli bir gündem maddesi haline gelmiş, bir krize sebebiyet vermesinin önüne geçmek isteyen Yıldızın lütuf ve ihsanlarına mazhar olmuştur. II. Abdülhamid'in verdiği unvanla "bey" olarak anılmaya başlayan İsa, elde ettiği menfaatlerini korumak ve bunlara yenilerini eklemek için İttihat ve Terakki'ye dolayısıyla Meşrutiyet düzenine muhalif bir tavır takınmıştır. Rejime muhalefetiyle başlayan yeni süreç ve yaşanan olaylar onu Arnavut ulusçuluğunun bir parçası haline getirmiştir. Buna bağlı olarak Balkan Harbine kadar devam eden Arnavut isyanlarının önemli bir aktörü olmuştur. Balkan Savaşı ve I. Dünya Savaşı boyunca Kosova topraklarını düşman işgallerine karşı savunmaya çalışan İsa, bugün Kosova Arnavutlarının millî bir kahramanı olarak kabul edilmektedir.

Anahtar Kelimeler: İsa Bolatinî, Kosova, Mitroviçe, Arnavutluk Meselesi, İttihat ve Terakki

\begin{abstract}
İsa Boletini took part in many significant incidents that occurred in Rumelia in the last period of the Ottoman Empire as a result of both the geography and period he lived in and the networks he established. While he was mentioned as a bandit in the first state correspondences, his oppression on the Muslim and Christian people in the region where he lived was being uttered. Considered as the biggest obstacle for the foundation of an embassy in Mitrovica by Russia, which wanted to exist in the region over time, Isa became a crucial item of the agenda in the diplomatic negotiations. He was honored with the grace and bestowal of Yildiz, which wanted to stop him from causing a crisis. Isa, who started to be addressed as "bey" with the title given by Abdulhamid II, adopted an attitude against the Committee of Union and Progress, thus, the Constitutional order in order to protect his own interests and obtain new ones. The new process that started with his opposition against the regime and the occurring events made him a part of the Albanian nationalism. Accordingly, he became an important actor of the Albanian rebellions which continued until the Balkan War. Isa, who tried to defend Kosovo's territory against the hostile occupations during the Balkan War and World War I, is now considered a national hero of Kosovo Albanians.
\end{abstract}

Keywords: Isa Boletini, Issa Boletinatz, Kosova, Mitrovica, Albanian Question, Committee of Union and Progress

ATIF: OLGUN Said, “Kosova Arnavutlarının Millî Kahramanı İsa Bolatinî (1864-1916)”, Tarih ve Gelecek Dergisi, 6/3 (Eylül 2020), s. (855-894)

CITE: OLGUN Said, "National Hero Of Kosovo Albanians Isa Boletini (1864-1916)", Journal of History and Future, 6/3 (September 2020), pp. (855-894) 


\section{Giriş}

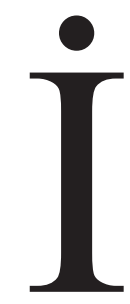

sa Bolatinî’nin doğup yaşadığı Mitroviçe 28 Haziran 1389 tarihli I. Kosova Savaş1 sonunda Prizren ve çevresiyle birlikte Osmanlı hakimiyetine girmiştir. Kuzeyde Bosna ve Sancak’a, güneyde İstanbul'a geçişi sağlayarak bir köprü vazifesi gören şehir, 17. yüzyıla kadar gelişim göstermişse de yüzyılın sonlarında meydana gelen Osmanl1Avusturya Savaşlarından Prizren ve civarıyla beraber olumsuz bir şekilde etkilenmiştir. 1877-1878 Osmanlı-Rus Savaşı'ndan sonra imzalanan Ayastefanos Anlaşması ile Sırbistan'a bağımsızlığı verilmiştir. Osmanlı Devleti'nin Sırbistan'a bırakmak zorunda kaldığı önemli toprak parçalarından biri de Mitroviçe olmuştur. Ayastefanos Anlaşması'nın tadili niteliğindeki 13 Temmuz 1878 tarihli Berlin Antlaşması ile tekrar Osmanlı Devleti'ne iade edilen şehir, Balkan Savaşı sonunda bir kez daha Sırbistan'a terk olunmuştur. Günümüzde Kosova sınırları içerisinde yer alan Mitroviçe, Osmanlı hakimiyetinden çıkışından sonraki yıllarda bölgenin paylaşılamayan şehirlerinden biri olarak tartışmaların konusu olmuştur. ${ }^{1}$

Kosova vilayetinin Priştine sancağına bağlı bir kasaba olan Mitroviçe, Kuzey Arnavutluk’un en önemli askerî merkezi olmuştur. Sırbistan hududuna oldukça yakın olan kasaba, sınırı bekleyen askerî fırka için merkez kabul edilmiştir. Bu nedenle firkadaki Jön Türklerin varlığı ile Sırbistan'a yakın olması imparatorluğun hem içinde hem de dişında meydana gelen gelişmelerin kasabada ve bölgede hızlı bir şekilde yayılmasını sağlamıştır. ${ }^{2}$ Doksan Üç Harbi sonrası bu küçük kasaba Büyük Güçler arasındaki rekabetin bir merkezi haline gelmiştir. Rusya, bölgeyi hem Osmanlının hem de Avusturya'nın yönettiği topraklara sızmak ve yerel Ortodoks Slavlar üzerinde nüfuz kurabilmek için önemsemiştir. Avusturya-Macaristan İmparatorluğu bölgeyi kurduğu manastır ve kiliselerle oluşturduğu ağ ile Habsburg Katolik propagandasının tohumlarını serpmek için kullanmıştır. Sırbistan ise bölgeyi Osmanlı ülkesindeki esnek müttefikleri için silah kaçakçılığı amaciyla kullanmıştır. ${ }^{3}$

İngiliz diplomat Aubrey Herbert'in, biraz da abartarak, Arnavutların Robin Hood'u olarak nitelendirdiği İsa Bolatinî’nin yaşadığı Mitroviçe ve çevresinin önemli isimlerinden biri olduğu yadsınamaz bir gerçektir. Sırbistan-Osmanlı sınır hattının bölgeye sağladığı avantajı çok iyi bir şekilde değerlendirmeyi bilen İsa, sınır ötesiyle zaman içerisinde kurduğu güçlü ticari, politik ve sosyal ağlar vasıtasıyla bir yandan kendini kanıtlama imkanı bulurken bir yandan da yerel gücünün temellerini inşa etmiştir. ${ }^{4} 1900$ 'lü yılların başından itibaren Rusya ve müttefikleri için bölgede kontrol edilemez bir güç olarak görülmeye başlanan İsa diplomatik krizlerin ana gündem maddesi haline gelmiştir. Yıldızla tesis ettiği bağ ve buna bağlı olarak mazhar olduğu lütuf ve ihsanlar onu monarşinin yılmaz bir savunucusu haline getirmiştir. Elde ettiği kazanımlarını kaybetmemek ve menfaatlerini korumak için Meşrutiyet karşıtı bir tavır takınmıştır. Meşrutiyet düzenine ve dolaysıyla İttihat ve Terakki Cemiyetine muhalefeti onu muhalif çevrelerle iş birliğine sevk etmiştir. Buna bağlı olarak Arnavut ulusçusu bir pozisyon almıştır.

1 Güler Yarc1, “Kosova'nın Hüzünlü Yüzü: Paylaşılamayan Şehir “Mitroviçe””, Bozkırdan Batıya (Prof. Dr. Hüseyin Salman'a Armă̆an), ed. Güler Yarc1, Epilson Yayınevi, 1. Bask1, İstanbul, 2017, s. 375.

2 Mustafa Ragıb, Meşrutiyet'ten Önce Manastır'da Patlayan Tabanca, Yay. haz. Rahşan Aktaş, Belgi Yay., 1. Baskı, İstanbul, 2007, s. 194.

3 Isa Blumi, Reinstating the Ottomans, Palgrave Macmillan, 1st Published, New York, 2011, p. 144.

4 Blumi, age., s.145. 
Yoğun bir şekilde Osmanlı arşiv belgeleri kullanılarak hazırlanan bu çalışmada konu ve incelenen dönemle ilgili hatıratlar, yerli ve yabancı gazeteler ile telif eserlerden istifade edilmiştir. Böylece yaşadığı dönemde içerisinde yer aldığı olaylarla ilgili kaleme alınan eserlerde hakkında bir takım bilgi kırıntılarına yer verilen İsa Bolatinî’nin hayat öyküsü bir bütün olarak incelenmeye çalışılmıştır.

\section{Ailesi ve İlk Gençlik Yılları:}

İsa Bolatinî’nin ailesi aslen Kosova'nın Deçan bölgesinde yer alan İsnik (Isnıq/Istinic) köyündendir. Bu dönemde Arnavutlar arasında yaygın bir şekilde görülen kan davası nedeniyle burayı terk etmek zorunda kalan aile, Kosova vilayetinin Priştine sancağına bağlı Mitroviçe kazasının Bolatin isimli köyüne yerleşmiştir. ${ }^{5}$ Şale kabilesine mensup olan aile, zamanla sonradan yerleşmiş oldukları köye izafeten Bolatinî şeklinde anılmıştır.

Annesinin adı Ayşe, babasının adı Adem olan İsa, 15 Ocak 1864'te Bolatin'de doğmuştur. Yaygın bir şekilde memleketine nispetle İsa Bolatinî veya İsa Bey Bolatinî şeklinde anılmıştır. ${ }^{6}$ 1877-1878 Osmanl1-Rus Harbi sonrası Arnavutlar tarafından kurulan Prizren Birliğine katılmış daha on yedi yaşında iken 22 Nisan 1881'de Slivova Savaşı'nda Derviş Paşa komutasındaki Osmanlı birliklerine karşı savaşmıştır. ${ }^{7}$ Ancak Derviş Paşa, Firzovik yakınlarında 29 Nisan 1881 'de Prizren İttihat Cemiyeti birliklerini mağlup ederek bölgede devlet otoritesini yeniden tesis etmiştir. ${ }^{8}$

1913 yılının Haziran ayında Londra' da bulunduğu sırada Saturday Mail gazetesine bir mülakat veren İsa Bolatinî, on yedi yaşından beri savaştığını ifade ettikten sonra ilk düşmanlarının Sırplar ve Karadağlılar olduğunu, onlara karşı işgal edilen topraklarını müdafaa etmek için mücadele ettiğini belirtmiştir. ${ }^{9}$ Öyle anlaşılıyor ki on yedi yaşında olduğu 1881 yılında eline aldığı silahını elli iki yaşındayken öldüğ̈̈ 1916 yılına değin geçen otuz beş yıl boyunca bırakmamıştır. Hayatı boyunca süren mücadelesinde karşısındaki kuvvetler kimi zaman Osmanlı birlikleri kimi zaman da işgalci Sırp ve Karadağ birlikleri olmuştur. Hayatını sürdürdüğü Mitroviçe bölgesindeki kural tanımaz tavrı, Müslüman ve Hıristiyan tebaaya zulmü, kanun kaçaklarını barındırması, haklı olarak, onun "şâki" olarak nitelendirilmesine sebep olmuştur.

\section{Eşkıya-yı Meşhureden İsa Bolatinî}

İsa hakkında tespit edebildiğimiz en eski Osmanlı arşiv belgesi 1895 yılına aittir ki burada onun "şâki ve kâtil takımından" olduğu ve öteden beri Müslüman ve Hiristiyan halka tecavüzde

5 Gail Warrander, Verena Knaus, Kosova, Bradt Travel Guides Ltd, 1st Edition, Buckinghamshire, 2007, S. 264. Arnavutlar arasında kan davaları hakkında bk. Bilgin Çelik, “Geleneksel Yapı ile Modernite Arasındaki Gerilime Bir Örnek: Arnavutluk’ta Kan Davaları ve II. Meşrutiyet Döneminde Soruna Çözüm Arayışları”, Studies of the Ottoman Domain, C. 4, S. 7 (Ağustos 2014), ss. 18-41. Özer Özbozdağl1, "Osmanlı Hükümetinin Kosova Arnavutları Arasındaki Kan Davalarına Çözüm Bulma Çabalar1 1908-1912”, Belleten, C. LXXXII, S. 295 (Aralık 2018), ss. 979-1011.

6 Robert Elsie, "Boletini, İsa Bey (15 January 1864-23 January 1916)”, Historical Dictionary of Kosovo, The Scarecrow Press, 2nd Edition, Lanham, 2011, p. 48. İngiliz gazetesi The Mercury’de İsa hakkında kaleme alınan bir makalede onun 1870 yılının soğuk bir Mart sabahında doğduğu; annesinin dünyaya yeni gelen oğlu hakkında bir öngörüde bulunarak onun kan içerisinde yaşayacağını ancak huzur içerisinde öleceğini söylediği ifade edilir. Makalede İsa'nın daha üç yaşındayken haydutlar tarafından öldürülerek yol kenarına atılan bir Arnavut'un cesedinin kanıyla oynarken bulunduğu bilgisine de yer verilmiştir. "An Albanian Brigand The Career of Issa de Boletini”, The Mercury, December 14, 1912, p. 9.

7 Elsie, agm., p. 48.

8 Yücel Yiğit, "Milliyetçilik Çağında Prizren İttihat Cemiyeti”, Turkish Studies, Vol. 4/8, Fall 2009, s. 2476.

9 “Albanian Chief Issa Bolitenatz”, Saturday Mail, June 21, 1913, p. 2. 
bulunduğu belirtilmektedir. Bu durumda o günlerde otuzlu yaşlarının başında olan İsa'nın on yedi yaşında eline aldığı silahını Sırp ve Karadağlı işgalciler ile Osmanlı askerlerinden sonra halka da çevirdiği anlaşılmaktadır.

1895 yılının Haziran ayında Kosova Valiliği ve Priştine Mutasarrıflığı tarafından bölgede uzun zamandır halka zulmeden İsa Bolatinî, Şaban ve onlarla birlikte hareket eden arkadaşlarının yakalanması amacıyla askerî bir takım tedbirler alınmıştır. Hatta Priştine Mutasarrıfı Rauf Paşa, bizzat Mitroviçe'ye giderek İsa Bolatinî’nin yakalanması için düzenlenen askerî harekata refakat etmiş̧ir. Yüzbaşı Mehmed Efendi komutasındaki birlik, hazırlamış oldukları planda kontrol altında bulundurmaya karar verdikleri noktaları tutmaksızın üç kol halinde İsa'nın kulesini ablukaya almışlardır. Müsadereden kaçarak kurtulmayı başaran İsa, adamlarıyla birlikte tuttuğu hâkim bir noktadan askerler üzerine ateş ederek Yüzbaşı Mehmed Efendi'yi şehit etmiş ikisi çavuş ikisi de er olmak üzere dört askeri de yaralamıştır. ${ }^{10}$

Süleyman Külçe'nin bir "dağ haydudu" olarak nitelendirdiği İsa, ${ }^{11}$ yaşadığı bölgedeki Müslümanların mallarını gasp ederek burada bir güç unsuru haline gelmiştir. 1898-1899 yıllarında Mitroviçe bölgesindeki Sırp Ortodoks cemaatini korumakla görevli paralı "muhafızlardan" biri olmuştur. Sırbistan hükümeti, İsa'yı "reayanın koruyucusu" olarak yapmış olduğu hizmetleri nedeniyle bir madalya ile ödüllendirmiş ve ona silah tedarikinde yardımcı olmuştur. ${ }^{12}$

1900 yılında iki askeri şehit eden üç jandarma eri, kaçarak İsa'ya sığınmışlardır. Kendisine sığınanları teslim etmekten imtina etmiş bununla da kalmayarak affedilmelerini istemiştir. İsa, oldukça tehditkâr bir biçimde affedilmedikleri müddetçe başında bulunduğu Şale kolunun hiçbir şekilde vergi ödemeyeceğini, bölgedeki Hıristiyan halkı hicrete mecbur edeceğini ifade etmiştir. Hükümet, onun bu meydan okur tavrı karşısında askerî harekât düzenlemek için hazırlıklara girişmişse de vergi tahsildarları ile onları koruyan jandarmaları serbest bırakmış olmasını göz önünde bulundurarak bundan vazgeçmiştir. Harekatın başlatılamamasının esas nedeni İsa'nın bulunduğu bölgenin engebeli yapısı ve harekâtı gerçekleştirecek birliğin bir sonuç alabilmesi için en az iki taburdan oluşması gerekliliğiydi. Vazgeçilen askerî harekatın yerine hükümet daha zahmetsiz bir çözüm bulmuştur. İsa'ya nasihatte bulunularak ondan "muamelât-1 hükümete ve tahsilata müdahale" etmeyeceğine dair kuvvetli bir söz alınmış ve kendisine sığı̆nanların adliyeye sevk edilmesi sağlanmıştır. ${ }^{13}$

Her ne kadar bir dönem ücret mukabili olsa da Ortodoks Sırpların koruyuculuğunu üstlenmiş olan İsa, Mitroviçe'deki Hüseyin Ferhad, Şaban, Şerif ve İlyas isimlerindeki diğer eşkıyalarla birlikte Hıristiyan ahalinin en fazla korktuğu ve çekindiği isimlerden biri olmuştur. Hıristiyanlar, hükümete yazdıkları arzuhallerde, karşılaştıkları güçlükleri biraz da abartarak, Müslüman Arnavutlar tarafından çarşı ortasında katledildiklerini, çarşıya çıkmaya cesaret edemediklerini bu nedenle ailelerinin korku içerisinde evlerine kapanmak zorunda kaldıklarını, Irz ve namuslarının tehlikede bulunduğunu belirterek karşılaştıkları muamele nedeniyle bölgeden göç etmeyi düşündüklerini

10 Cumhurbaşkanlığı Devlet Arşivleri Başkanlığı Osmanlı Arşivi (BOA), Yıldız Perakende Sadaret Maruzatı (Y.PRK.A), 10/15, H. 14.12.1312 (8 Haziran 1895). BOA, Dahiliye Nezareti Şifre Kalemi (DH.ŞFR), 174/99, R. 27.03 .1311 (8 Haziran 1895).

11 Süleyman Külçe, Firzovik Toplantısı ve Meşrutiyet, Yay. haz. İsmail Dervişoğlu, İsmail Küçükkılınç, Kitabevi Yay., 1. Bask1, İstanbul, 2013, s. 82.

12 Noel Malcolm, Kosova Balkanları Anlamak Iç̧in, çev. Özden Arıkan, 1. Bask1, Sabah Kitapları, İstanbul, Mart 1999, s. 291. George Gawrych, The Crescent and the Eagle: Ottoman Rule, Islam and the Albanians, 1874-1913, I. B. Tauris, New York, 2006, p. 134.

13 BOA, Dahiliye Nezareti Mektubî Kalemi (DH.MKT), 2388/141, H. 16.04.1318 (13 Ağustos 1900). 
ifade etmişlerdir. ${ }^{14}$ Yaşanan gelişmeler üzerine 28 Kasım 1901 tarihli bir iradeyle İsa Bolatinî, İlyas, Şaban ve Şerif' in Konya'ya sürülmeleri istenmiştir. ${ }^{15}$ İsa Bolatinî ile diğer “eşirranın” Mitroviçe'deki varlıkları devam ettiği müddetçe asayiş ve güvenliğin temin edilemeyeceğinin bundan dolayı da halkın rahat ve refahının sağlanamayacağının farkında olan Kosova Valisi Reşad Bey, bir an önce askerî bir harekât düzenlenerek yakalanıp etkisiz hale getirilmeleri düşüncesindedir. ${ }^{16}$ Ancak böyle bir teşebbüste bulunulmadığı ya da düzenlenen askerî harekattan istenilen sonuç elde edilemediği için İsa Bolatinî Mitroviçe'deki varlığını sürdürmüş ve bir müddet sonra yaşananlar onun talih gemisini bir başka limana sürüklemiştir.

\section{Rus Konsolosluğunun Önündeki Engel: İsa Bolatinî}

Rumeli coğrafyasında artan Avusturya-Rusya rekabetinin bir sonucu olarak her iki ülke bölgede çok sayıda konsolosluk kurarak varlıklarını pekiştirmeye çalışmışlardır. Bu noktada kendi ideoloji, mezhep ve meşreplerine bağlı olarak farklı gruplarla menfaat ilişkileri tesis etmişlerdir. Konsolosların bulundukları bölgedeki Ortodoks veya Katolik halkın hamiliğini üstlendikleri gerekçesiyle birtakım bahanelerle Osmanlı Devleti'nin iç işlerine müdahale etmeleri, diplomatik dokunulmazlıktan istifade ederek devlet ve hükümet aleyhinde yürütülen faaliyetlere aracılık etmeleri ve zaman zaman halkı birbirine düşürerek bir kaos ortamı oluşturmak yönündeki çabaları, Osmanlı Devleti tarafindan dikkatle takip edilmiş ve buna karşı birtakım tedbirler alınmaya çalışılmıştır. ${ }^{17}$

Bölgedeki etkinliğini artırmak çabasındaki Rusya'nın Mitroviçe'ye bir konsolos tayin edeceği haberi, konsolosun gelişinden tam bir yıl önce konuşulmaya başlanmıştır. Rusya'nın Mitroviçe'ye bir viskonsolos tayin edeceğini hatta atanacak kişinin İşkodra eski viskonsolosu Scherbiana olacağını Üsküp’teki Rusya konsolosundan öğrenen Kosova Valisi Reşad Bey, bu durumu oldukça yadırgamıştır. Mitroviçe gibi küçük bir şehre konsolos tayinini hiçbir gerekçe ile ilişkilendiremeyen Vali, bu gelişmenin çevredeki devletler için bir emsal oluşturabileceği ve neticede kasabanın bundan zarar göreceği düşüncesindedir. ${ }^{18}$

Kasabaya bir Rus konsolosunun atanacağı haberi, yalnızca devlet erkanının konuşup sonuçlarının neler olabileceğini kestirilmeye çalıştığı bir konu olmamıştır. Kosova Valisi Reşad Bey'in 17 Haziran 1902'de Dahiliye Nezaretine gönderdiği bir telgraf, konunun halkın da gündeminde olduğunu ve gelişmeleri yakından takip ettiğini göstermektedir. Valinin Priştine Mutasarrıflığından gelen bir telgrafa istinaden aktardığına göre halk, gelmesi durumunda konsolosu katletmeye ahdediyordu. Telgrafta ayrıca "vahşet ve huşunet-i tabiileri” ile bilinen Mitroviçelilerin devleti siyasî bir meselenin içerisine sürükleyecek bir cinayeti işlemekten çekinmeyecekleri de ifade edilmiştir. ${ }^{19}$

Bölgeden gelen haberler nedeniyle ileride önü alınamayacak meselelerin ortaya çıkmasından endişe eden hükümet, Hariciye Nazırı Tevfik Paşa aracılığıyla Rusya Sefiri Zinoviev ile görüşerek Rusları konsolosluk açmak fikrinden vazgeçirmeye çalışmıştır. Ancak Sefir, konsolosluk açma

14 BOA, DH.ŞFR, 268/58, R. 15.08 .1317 (28 Ekim 1901).

15 BOA, Yıldız Sadaret Hususi Maruzat Evrakı (Y.A.HUS), 434/12, H. 04.06.1320 (8 Eylül 1902).

16 BOA, DH.ŞFR, 271/16, R. 17.09.1317 (30 Kasım 1901).

17 Avusturya konsoloslarının Arnavutluk coğrafyasındaki faaliyetleri hakkında bk. Said Olgun, "Avusturya-Macaristan İmparatorluğu Konsoloslarının Arnavutluk Coğrafyasındaki "Muzır Faaliyetlerine” Bazı Örnekler”, Uluslararası Sosyal Araştırmalar Dergisi, C. 10, S. 50 (Haziran 2017), ss. 245-255.

18 Kosova Valisi Reşad Bey'in 14 Ocak 1902 tarihli telgrafı, BOA, DH.MKT, 531/58, H. 24.06.1320 (28 Eylül 1902).

19 BOA, DH.MKT, 531/58, H. 24.06.1320 (28 Eylül 1902). 
emrinin Çar'dan geldiğini bundan dolayı da vazgeçilmesinin mümkün olamayacağını ifade ettikten sonra kendilerine söylenen sakıncaların meydana gelme ihtimali olmadığını belirtmiştir. Ayrıca Sefir, 1774 Küçük Kaynarca Antlaşması'nın on birinci maddesine istinaden Rusya'nın Osmanlı ülkesinde istediği yerlere konsolos tayinine yetkisi bulunduğunu dolayısıyla "itiraza mahal" olmadığını da dile getirmiştir. ${ }^{20}$

Hükümet, Kosova Valiliğinden Rus konsoloshanesinin açılacağ "şayiasından dolayı heyecana gelmiş" ahalinin içlerinden söz anlayanlar vasıtasıyla "temin ve tazmin" edilmesini istemiştir. Bu talep üzerine Vali Reşad Bey, 28 Ağustos 1902'de Hükümete gönderdiği cevabî telgrafinda Mitroviçeliler arasında bulunulması istenilen söz anlar takımından kimsenin olmadığını, işin büyümesinin nedeninin de aranılan adamların yokluğundan kaynaklandığını ifade etmiştir. Meselenin bu şekilde çözülebileceğine inanmayan Vali, konunun önemini de göz önünde bulundurularak her ne yapılması lazım geliyorsa Babıali'nin yapmasını istemiştir. ${ }^{21}$

Tüm tehditlere rağmen açılacak olan konsolosluğun hazırlıklarını yapmak amacıyla Eylül ayı başında Mitroviçe'ye gelen Rus konsolosunun kavası ve adamları orada kalmalarının sakıncalı görülmesi üzerine Üsküp'e sevk edilmişlerdir. Bu esnada İsa Bolatinî, Mitroviçelilerin direnişine Yenipazarlıları da dahil etmeye çalışmıştır. Öyle ki konsolosluk haberiyle heyecanlanan Yenipazarlılar hemen harekete geçmiş, halkın ileri gelenleri hükümete gönderilmek üzere bir yazı kaleme almaya girişmişlerdir. ${ }^{22}$

Hükümet, Rusya'yı konsolosluk açma fikrinden geri çevirmeye çalışırken, devletin bölgedeki nüfuzunu sorgulatacağı gerekçesiyle, muhataplarına konsolosluğu halkın istemediği ve gelecek konsolosa suikast düzenleneceği gibi gerekçeler sunmaktan çekinmiştir. Hariciye Nazırı Tevfik Paşa, bölgedeki asayişin temini ve konsolosların hayatlarının muhafazası yerel hükümetin sorumluluğunda olduğu için bu yolda bir sakınca belirtilmesinin "lisan-1 hükümete" yakışmayacağ ve Rusya'nın da bunu konsolosluk açma fikrinden feragat etmek için meşru bir sebep olarak görmeyeceği düşüncesindeydi. ${ }^{23}$

Ortaya çıkan manzara karşısında Sadrazam Said Paşa, 4 Eylül 1902'de konsolosluk açılmasına muhalefet edenlerin "iskât veya tedibleri" için vilayetçe tedbirler alınmasını istemiştir. ${ }^{24}$ Sadrazamın bu emri verdiği günün akşamında Hariciye Nazırı Tevfik Paşa'nın evine önemli bir ziyaretçi gelmiştir. Nazırı evinde ziyaret eden Rusya Sefareti Baştercümanı Maksimof'un gündeminde konsolosluk açılması aleyhinde propaganda yapan İsa Bolatinî bulunuyordu. Maksimof, geçen yıl teşebbüsleri neticesinde Mitroviçe'den kaldırılması için hakkında irade çıkarılan İsa Bolatinî’nin hala orada bulunduğunu, Rusya konsolosluğu memurları hakkında tehditkâr ifadeler kullandığını ve bir hadise çıkarmak için çalışmaktan geri durmadığını ifade ederek hükümetinin bu durumdan duyduğu rahatsızlığı belirtmiştir. Görüşmede Rus hükümetinin İsa'nın tutuklanmaması durumunda buna tahammül edemeyeceğini adeta sefaretin kapatılarak ilişkilerin kesilmesi derecesine kadar gidebileceğini ve hatta Osmanlı'nın bölgedeki nüfuzunu kaybettiğini gören Rusya'nın Düvel-i Muazzamaya müracaatla Avusturya ile bir ittifak yaparak Avusturya işgal kuvvetlerinin Mitroviçe'ye kadar uzanmasını sağlamaya mecbur kalacağını ifade etmiştir. Hariciye Nazırı,

20 Hariciye Nazırının 24 Haziran 1902 tarihli yazısı, BOA, DH.MKT, 531/58, H. 24.06.1320 (28 Eylül 1902).

21 Kosova Valisi Reşad Bey'in 28 Ağustos 1902 tarihli telgrafi, BOA, DH.MKT, 531/58, H. 24.06.1320 (28 Eylül 1902).

22 Sadrazam Said Paşa'nın 3 Eylül 1902 tarihli yazısı, BOA, DH.MKT, 531/58, H. 24.06.1320 (28 Eylül 1902).

23 Hariciye Nazırı Tevfik Paşa'nın 4 Eylül 1902 tarihinde Sadarete gönderdiği yazı, BOA, DH.MKT, 531/58, H. 24.06.1320 (28 Eylül 1902).

24 Sadrazam Said Paşa'nın 4 Eylül 1902 tarihli yazısı, BOA, DH.MKT, 531/58, H. 24.06.1320 (28 Eylül 1902). 
İsa Bolatinî'nin Mitroviçe'den uzaklaştırılmasını gerektirecek hal ve hareketi varsa bunun hükümetçe yapılacağını belirttikten sonra daha önce hiçbir devletin konsolosluğunun bulunmadığı Mitroviçe'nin durumunun ve ahalisinin mizacının göz önünde bulundurularak konsolosluk açma fikrinden feragat edilmesini istemiştir. Görüşme esnasında sözün dönüp dolaşıp İsa Bolatinî’ye geldiğini gören Tevfik Paşa, hükümete İsa Bolatinî hadisesine nihayet verilmesinin uygun olacağ yönündeki görüşünü de belirtmiştir. ${ }^{25}$

Maksimof'un Tevfik Paşa ile yaptığ 1 görüşmede geçen yıl İsa Bolatinî'nin Mitroviçe'den kaldırılacağına dair bir irade-i seniyyenin varlığından bahsetmesi bir anda tüm gözlerin İsa Bolatinî'ye ve bahsi geçen iradeye çevrilmesine sebep olmuştur. Elinde bu yolda bir irade ve bilgi bulunmayan Sadaret, bir yandan belgeye ulaşmaya çalışırken bir yandan da Dahiliye Nezareti nezdinde eğer böyle bir irade varsa neden uygulanmadığını sorgulamaya başlamıştır. ${ }^{26}$ En nihayetinde 1901 yılının Kasım ayında Hüseyin Ferhad'ın Mitroviçe çarşısında kuyumcu Gorgi'yi yaralaması ve hükümet konağı yakınındaki meydanda nümayiş yaparak kaçmasından sonra bölgede asayişin sağlanması için Hüseyin Ferhad'ın yakalanarak adliyeye teslim edilmesi, içlerinde İsa Bolatinî’nin de bulunduğu Şaban, Şerif ve İlyas isimlerindeki eşkıyanın Konya'ya tebid edilmeleri için 28 Kasım 1901'de bir irade çıkarıldığı anlaşılmıştır. ${ }^{27}$ İsa'nın Mitroviçe'den uzaklaştırılması yönündeki bu ilk kararın bir diğer nedeni de bir dönem koruyuculuklarını yaptığı Sırpları taciz etmesidir. İlk etapta Belgrad hükümeti daha sonra da Sırpların talebi üzerine Rus hükümeti bölgeden uzaklaştırılması yönünde Osmanlı'ya yoğun baskı yapmışlar ve neticede böyle bir karar alınmıştır. Ancak uygulamaya konulmamış veya bu noktada bir kararlılık gösterilmemiştir. ${ }^{28}$

Mitroviçe'yi Arnavutluk'un göbeği olarak nitelendiren Kosova Valisi Reşad Bey, hiçbir devletin konsolosluğunun bulunmadığı kasabada açılacak bir Rus konsolosluğunun diğer devletleri de harekete geçireceğinden ve sadece Mitroviçe ile yetinmeyip Yenipazar, İpek ve Prizren'e de birer konsolos tayin etmekten geri durmayacaklarından endişe etmekteydi. İleride devleti müşkül duruma düşürecek bir hadisenin meydana gelmesini istemeyen Vali, konsolosluğun açılışının İsa Bolatinî gibi kişilerin bölgeden uzaklaştırılması ve halkın teskin edilmesinden sonraya bırakılmasını ve hatta mümkün olduğunca ertelenmesi gerektiği düşüncesindedir. ${ }^{29}$

Osmanlı Devlet erkanı Mitroviçe'ye tayin edilen Rus konsolosunun kasabaya gelişini ve göreve başlamasını mümkün olduğunca geciktirmeye çalışırken Rus Sefareti de aynı nispette süreci hızlandırmak için mücadele etmiştir. 7 Eylül sabahı bir kez daha Hariciye Nazırı Tevfik Paşa'yı ziyaret eden Rusya Sefareti Baştercümanı Maksimof, İsa Bolatinî'nin uzun bir süredir tebid edilememiş olmasının hükümetin bölgedeki nüfuzunun zaafına ve yokluğuna bir delil olarak nitelendirileceğini; konsolosun gelişinin bir müddet daha tehir edilse dahi konsolosluk tesis edildiği için Rus hükümetinin konsolos göndermekten vazgeçmeyeceğini ifade etmiştir. Görüşme esnasında Maksimof, İsa'nın bir an evvel yakalanmasını ve tayin edilen konsolosa beratının hemen verilmesini istemiş̧ir. Bunu dile getirirken tehditkâr bir tavır takınmaktan da geri durmayarak isteklerinin yerine getirilmemesi durumunda kırk sekiz saat içerisinde İsa'nın tebidini ve konsolosun tasdikini bir ültimatom ile talep edeceklerini ve eğer bundan da sonuç alamazlarsa diplomatik

25 Hariciye Nazırı Tevfik Paşa'nın 4 Eylül 1902'de Sadarete gönderdiği yazı, BOA, DH.MKT, 531/58, H. 24.06 .1320 (28 Eylül 1902).

26 Sadrazam Said Paşa'nın 5 Eylül 1902'de Dahiliye Nezareti'ne gönderdiği yazı, BOA, DH.MKT, 531/58, H. 24.06.1320 (28 Eylül 1902). BOA, Y.A.HUS, 434/6, H. 03.06.1320 (7 Eylül 1902).

27 BOA, Y.A.HUS, 434/12, 04.06.1320 (8 Eylül 1902).

28 Tahsin Paşa, Yıldız Hatıraları, Yay. haz. Ahmet Zeki İzgöer, İz Yayıncılık, 3. Baskı, İstanbul, 2018, s. 399.

29 Kosova Valisi Reşad Bey’in 7 Eylül 1902 tarihli yazısı, BOA, DH.MKT, 531/58, H. 24.06.1320 (28 Eylül 1902). 
ilişkileri kesmeye mecbur kalacaklarını belirtmiştir. ${ }^{30}$ Maksimof'un bu ifadelerinin ve ısrarının gerisinde Rusya'nın boğazlar ve Makedonya üzerindeki emellerinin bulunduğunun farkında olan hükümet, Rusya’ya firsat vermemek için devletin bölge üzerindeki nüfuzunu ispatlamak için İsa Bolatinî'nin Mitroviçe'den uzaklaştırılması amacıyla askerî hazırlıklar yapılması için Seraskerliğe gerekli emirlerin verilmesini kararlaştırmıştır. Hükümet, uzun bir süredir kurulmaması için çalıştığ konsolosluk konusunda da geri adım atarak tayin edilen konsolosa berat verilmesine de karar vermiştir. Tüm bunların yanı sıra yaşanılan kriz sürecini iyi yönetemediği görülen Kosova Valisi Reşad Bey'in de "adem-i kifayeti” nedeniyle görevden alınarak yerine "ümera-yı askeriyeden muktedir ve dekayık-1 umur-1 mülkiyeye vakıf bir zatın tayini elzem” görülmüştür. ${ }^{31}$

Hükümetin bu kararından sonraki en önemli gündem maddesi İsa Bolatinî olmuştur. Mitroviçe’ye bir Rus konsolosunun tayin edileceğini öğrendiği ilk günlerden itibaren buna karş1 çıkan Bolatinî, Mitroviçe, Yenipazar ve İpek’te halkı bir direniş için örgütlemeye çalışmıştır. ${ }^{32}$ Hükümet, yaşanan hadiselerden sonra kararlı bir şekilde İsa'yı Mitroviçe'den uzaklaştırmaya çalışırken İsa da hükümete sempatik görünmek adına adımlar atmıştır. Tabi bunu yaparken ortaya çok ironik bir durumun çıktığını da belirtmek gerekir. Kosova Valisi Reşad Bey’e gönderdiği adamlarıyla devletin eşkıyaya karşı yürüttüğü mücadelede devletin yanında olduğunu bütün kabilesiyle "eşirraya" karşı hücum etmeye hazır olduğunu bildirmiştir. Ancak Valilik, merkezî hükümetin buna razı olmadığını belirterek İsa’nın eşkıyaya saldırmasının önüne geçmiştir. ${ }^{33}$

Aynı günlerde İsa'nın hükümetin kendisine karşı yapabileceği muhtemel bir askerî harekata karşı hazırlık yaptığı konuşulmaya ve Kosova Valiliğine bu yönde ihbarlar gelmeye başlamıştır. Valiliğe gelen ihbarlara göre Rus konsolosluğunun açılmasını "menafi-i İslamiyyeye mügayir" bir durum olarak nitelendiren İsa, eğer hükümet kendisine karşı ciddi bir teşebbüste bulunacak olursa, Sırbistan ile bir savaş çıkarmak için hazırlık yapmaya başlamıştır. Hatta istihbarata göre yaptığı hazırlıklar çerçevesinde peksimet imal ettirmektedir. Mitroviçe kaymakamlığının yaptığ1 tahkikatla İsa'nın kulesinde bulunduğu kendi kabilesiyle birlikte Yenipazar ve İpek'te adam toplamaya çalıştığı ancak bunun da ciddi bir yekûn tutmadığı anlaşılmıştır. Yukarıda da belirtildiği üzere hükümetin kendisine karşı kararlı bir tavır takındığını gören İsa, bir yararlılık göstererek "başının selametini temin" etmeye çalışmıştır. ${ }^{34}$

Hükümeti telaşlandıran bir başka gelişme Avusturya basınında yer alan bir haber olmuştur. ${ }^{35}$ Morgen Zeitung gazetesi, 18 Eylül'de yayımlanan nüshasında İpek'ten aldığ 1 bir telgrafa dayandırarak İsa Bolatinî’nin Osmanlı askerine mukabelede bulunmak amacıyla bin kişi topladığ 1 ve Rus konsolosu gelir gelmez katledeceğini söylediği bilgisine yer vermiştir. Viyana Sefareti aracılığıyla durumdan haberdar olan hükümet, bir an önce söz konusu haberin doğru olup olmadığının araştırılarak gerekli tedbirlerin alınmasını, eğer doğruysa İsa'nın topladığı adamların dağıtılarak istenmeyen olayların önüne geçilmesini istemiştir. Mitroviçe Fırkası Kumandanlığınca yapılan tahkikat neticesinde konsolosluk çalışanlarının ve eşyalarının Mitroviçe’ye gelişinin halkı heyecanlandırdığı bunun da arkasındaki kişinin İsa Bolatinî olduğu tespit edilmiştir. İsa'nın teşvikiyle oluşan huzursuz ortam onun Yenipazar ve İpek halkını kendi yanına çekmeye çalışmasıyla daha da yayılmışsa da konsolosluk çalışanlarının ve eşyalarının Üsküp'e gönderilmesiyle sükûnet

30 BOA, Y.A.HUS, 434/12, 04.06.1320 (8 Eylül 1902).

31 Sadrazam Said Paşa'nın 7 Eylül 1902 tarihli tezkiresi, BOA, Y.A.HUS, 434/12, 04.06.1320 (8 Eylül 1902).

32 BOA, DH.ŞFR, 292/88, R. 07.07.1318 (20 Eylül 1902).

33 BOA, Yıldı Mütenevvi Maruzat Evrakı (Y.MTV), 234/122, H. 17.06.1320 (21 Eylül 1902).

34 BOA, DH.ŞFR, 293/50, R. 11.07 .1318 (24 Eylül 1902). BOA, DH.MKT, 531/58, H. 24.06.1320 (28 Eylül 1902).

35 BOA, Hariciye Nezareti Siyasi (HR.SYS), 118/4, M. 19.11.1902. 
sağlanmış, bölgeye sevk edilen iki tabur askerî birlikle de birtakım tedbirler alınmıştır. Mitroviçe Fırkası Kumandanı Şemsi Paşa, hali hazırda Mitroviçe'de konsolosluk meselesinden dolayı toplanmış bir cemiyetin bulunmadığını konsolosluk kurulacak ise memurlar ve eşyaları gelmeden bir hafta önce haber verilmesini böylece halka nasihatte bulunularak teskin edilebileceklerini eğer cemiyet kurma yoluna giderlerse bunların da askerî tedbirlerle engellenebileceğini ifade etmiştir. ${ }^{36}$

27 Eylül 1902 tarihinde Dahiliye Nezaretinden Babıali’ye gönderilen bir yazıda Bulgaristan’da yayımlanan bir gazetede Mitroviçe ahalisinin Rus konsoloshanesinin tesisinden dolayı korku ve dehşet içerisinde bulunduğu şehrin İsa Bolatinî’nin nüfuzu altında olduğu, Vulçitrin ve Priştine Arnavutlarının da ona iltihak ettikleri ve İsa'nın Mitroviçe'ye gelen konsolosu şehre girdiği an öldüreceğine yemin ettiği şeklindeki ifadelere yer verildiği belirtilmiştir. Artık İsa Bolatinî’nin halkın cehaletinden istifade ederek onları Rusya konsolosluğuna karşı kışkırttığ1 ve bu durumun devletin bölgedeki nüfuzunu sekteye uğrattığı ve eğer önü alınmazsa devletin başına daha büyük gaileler açacağı herkes tarafından kabul edilmiştir. Bundan dolayı da sığındığı muhkem kulesinin top kullanılarak tahrip edilmesi konuşulmaya başlanmıştır. ${ }^{37}$

İsa, bir yandan konsolosu Mitroviçe'de barındırmayacağını ${ }^{38}$ ayak basar basmaz öldüreceğini söylerken bir yandan da Rus Konsolosluğu için evini kiralayacak olanı boğazlayıp evini yakacağı tehdidinde bulunmuştur. ${ }^{39}$ İsa'nın bölge halkını etrafına toplamaya başlaması, hükümeti her geçen gün biraz daha telaşlandırırken aynı zamanda İsa meselesini daha fazla uzamadan çözüme kavuşturmak için teşvik etmiştir. ${ }^{40}$ Buna bağlı olarak Dahiliye Nezareti, Seraskerlikten İsa Bolatinî’nin kısa süre içerisinde yakalanmasını istemiştir. ${ }^{41}$

\section{İstanbul'a Gidişi}

Hükümetin aldığı tedbirlerle iyice köşeye sıkışan İsa Bolatinî, daha fazla ileri gidemeyeceğini görmüş ve uzun süredir peşinde bulunan Mitroviçe Fırkası Kumandanı Şemsi Paşa'ya "sağlam ve muteber bir zatla" haber göndererek eğer Mabeynden kendisine hitaben İstanbul'a hareketi hakkında bir irade tebliğ buyurulursa, değil İstanbul'a gitmeye kendisini denize bile atmaya razı olacağına "besa" verdiğini bildirmiştir. Haberi alan Ferik Şemsi Paşa, hükümete çektiği 8 Ekim tarihli telgrafında onun bu yolla kan dökülmeksizin Mitroviçe’den uzaklaştırılmasının daha münasip olacağ 1 tavsiyesinde bulunmuştur. ${ }^{42}$

İsa'nın İstanbul'a sevk edilmesi talebi hem hükümet hem de Yıldız tarafından olumlu karşılanmış, 13 Ekim Salı günü trenle Mitroviçe'den İstanbul'a doğru hareket etmesi kararlaştırılmıştır. Bu arada Selanik Üçüncü Ordu Müşiri Hayri Paşa, İsa'nın İstanbul'a gitme bahanesiyle Selanik taraflarına kaçmasına ve yeni sıkıntıların oluşmasına firsat verilmemesi için teyakkuzda olunmasını istemiştir. ${ }^{43}$ Gelişmeleri anbean takip eden Babıali, başta Seraskerlik olmak

36 BOA, Babıali Evrak Odası Evrakı (BEO), 1926/144393, H. 24.06.1320 (28 Eylül 1902).

37 BOA, DH.MKT, 531/58, H. 24.06.1320 (28 Eylül 1902).

38 "The Balkan States", London Evening Standard, October 3, 1902, p. 5.

39 Hasip Saygıl1, “Sultan II. Abdülhamid'in Meşruiyet Krizi: 1903'te Mitroviçe'de İlk Rus Konsolosu Grigori Şerbina'nın Öldürülmesi”, Hacettepe Üniversitesi Türkiyat Araştırmaları, S. 20 (Bahar 2014), s. 170.

40 BOA, BEO, 1929/144657, H. 02.07.1320 (5 Ekim 1902). BOA, BEO, 1930/144718, H. 03.07.1320 (6 Ekim 1902).

41 BOA, DH.MKT, 531/58, H. 24.06.1320 (28 Eylül 1902).

42 BOA, BEO, 1933/144958, H. 11.07 .1320 (14 Ekim 1902). Müfid Şemsi, El Hakku Ya'lû Velâ Yu'lâ Aleyh (Şemsi Paşa, Arnavudluk, Ittihad ve Terakki), Yay. haz. Ahmed Nezih Galitekin, Şehir Yay., 2. Bask1, İstanbul, 2007, s. 76.

43 BOA, Y.A.HUS, 436/27, H. 19.07.1320 (22 Ekim 1902). 
üzere ilgili tüm kurumlar aracılığıyla İsa'nın İstanbul'a sevkini gözlemlemiştir. ${ }^{44}$

Bu arada dikkat çekici bir şekilde Yıldız'dan yolculuk için hazırlık yapan İsa Bolatinî’ye o günlerde İstanbul'a gelmesinin uygun olmayacağı bundan dolayı da bir müddet Selanik'te kalmasının daha iyi olacağı şeklinde bir haber gönderilmiştir. Ancak İsa, verdiği "besa" üzerine İstanbul'a gitmeye razı olduğunu başka bir yere gitmeyeceğini ifade etmiş̧ir. ${ }^{45}$ İstanbul'a gitmeyerek Selanik'te kalması yönündeki telkinler karşısında endişelenen İsa, köyüne dönmüştür. Kendisiyle vedalaşmak için ziyaretine gelen akraba ve dostları tarafından da korkutulmuş ve bunun üzerine hiçbir tarafa gitmeye emin olmadığını bildirmiştir. ${ }^{46}$ İstanbul'a gitmesine müsaade edilmeyen İsa, Mitroviçe'de kalarak konsolosun gelişine mâni olacağına "besa" vermiştir. İsa'yı bu fikrinden döndürmek için "ferman-1 padişahiye itaat etmeyenlerin İslamiyet'ten hariç" olacakları şeklinde nasihatte bulunulmuştur. ${ }^{47}$

Bu arada Dahiliye Nezareti'nin İsa'nın kati surette yakalanması yönündeki talebi üzerine Kosova Valiliği tarafından hazırlıklar yapılmaya başlanmıştır. $\mathrm{Bu}$ çerçevede elli kişiyle birlikte sığındığı kulesinden çıkarılması ve yakalanması için bir kez daha top kullanılması gerekliliğinin ortaya çıkması üzerine hem Kosova Valiliği hem de Üçüncü Ordu Komutanlığı her ne yapılması gerekiyorsa yerine getirilmesini belirterek İsa'nın yakalanması kararlılığında olduklarını göstermişlerdir. ${ }^{48}$

Ferik Şemsi Paşa'nın 31 Ekim'de görüştüğü Yenipazar, Vulçitrin ve Mitroviçe'nin ileri gelen ulema ve eşrafı İsa'nın katıldığı toplantılarda konsolosluk konusunda "besa" verdiklerini ancak bunun devlete karşı olmadığını yalnızca konsolosun gelmemesini istirham etmek için olduğunu, Padişahın iradesiyle gelecek konsolosa karşı söyleyebilecekleri bir şey olmadığını ifade etmiş̧lerdir. ${ }^{49}$ Bununla birlikte içerisinde İsa Bolatinî’nin de bulunduğu Mitroviçe, Vulçitrin, İpek ve Yenipazar ileri gelenlerinden oluşan on yedi kişi, 2 Kasım 1902 tarihinde bir arzuhal kaleme almışlardır. Söz konusu yazıda bulunduğu yer açısından önemli bir konuma sahip olan Mitroviçe'nin etrafının düşmanla çevrilmiş olduğunu, şimdiye kadar dışarıdan yabancı ülkeler tarafından kışkırtılan Hıristiyan tebaanın konsolosun gelişiyle içeriden de kışkırtılacağını bunun da vatan topraklarının elden gitmesine sebep olacağını ifade etmişlerdir. Yazının devamında endişe içerisinde olan İpek, Yenipazar, Mitroviçe ve Vulçitrin ahalisinin mümkünse "Allah rızası için bu beladan" kurtarılmayı istedikleri "şayet kabili yok ise haşa" devlete isyan etmeyi ve devlete gelecek fenalığ hiçbir şekilde kabul etmeyeceklerini belirterek devlete ve Padişaha sadakatlerinin tam olduğunu ifade etmişlerdir. ${ }^{50}$

İsa Bolatinî meselesinin çok uzun bir süredir neticelendirilmemesi ve bir türlü Mitroviçe'den uzaklaştırılamaması Rusya Sefareti tarafından kızgınlıkla karşılanmıştır. Rusya Sefareti Baştercümanı, işin sürüncemede kalması ve İsa'nın tevkif edilememesinde Ferik Şemsi Paşa'nın gösterdiği acziyetin etkili olduğu görüşündedir. ${ }^{51}$ Bu noktada akıllara Ekrem Bey Vlora'nın bir iddiası gelmektedir. Ekrem Bey’e göre Arnavut olan Şemsi Paşa ile İsa Bolatinî kan kardeştirler.

44 BOA, BEO, 1934/145035, H. 11.07.1320 (14 Ekim 1902).

45 BOA, Y.A.HUS, 436/27, H. 19.07.1320 (22 Ekim 1902). BOA, BEO, 1936/145191, H. 19.07.1320 (22 Ekim 1902).

46 BOA, Y.MTV, 235/67, H. 12.07.1320 (15 Ekim 1902).

47 BOA, Y.MTV, 235/122, 23.07.1320 (26 Ekim 1902).

48 BOA, Y.MTV, 235/122, 23.07.1320 (26 Ekim 1902).

49 BOA, Yıldız Perakende Evrakı Askeri Maruzat (Y.PRK.ASK), 186/30, H. 30.07.1320 (2 Kasım 1902).

50 BOA, Y.PRK.ASK, 186/30, H. 30.07.1320 (2 Kasim 1902).

51 BOA, BEO, 1944/145768, H. 02.08.1320 (4 Kasim 1902). 
Hatta öyle ki İsa Bolatinî, 1908'de Jön Türkler tarafından öldürülen Şemsi Paşa'nın intikamını 1913 'te Resneli Niyazi'yi öldürterek almıştır. ${ }^{52}$ Lek Dukakin Kanunuyla da uyuşan bu iddianın doğru olup olmadığını tam olarak tespit etmek mümkün değildir. ${ }^{53}$ Çünkü Süleyman Külçe, İsa Bolatinî'nin Şemsi Paşa'yı sevmediğini ancak ölümüne üzülmüş göründüğünü ifade etmiştir. ${ }^{54}$ Ancak bir hakikat var ki o da her ikisinin de Abdülhamid'e güçlü bir sadakatle bağlı olmalarıdır. Baştercümana göre kendisini Müslümanların hamisi olarak gören ve etrafına iki yüz adam toplayan İsa'nın bu hareketi katliamlara ve istenmeyen olaylara sebebiyet verecektir. İsa'nın tehditleri ve varlığ nedeniyle konsolosun görevine gidemediğini belirten Baştercüman, bir kez daha bir an önce Konya'ya gönderilmesini istemiştir. ${ }^{55}$ Daha önce olduğu gibi Rusya'nın İsa Bolatinî'nin Konya'ya tebidini "bir mesele-i mühimme hükmüne" getirdiğinin, meselenin uzaması halinde devletin bölgedeki otoritesinin sorgulanmaya başlanacağının ve bunun bir takım siyasi sonuçlarının olacağının farkında olan hükümet, bir kez daha meselenin çözümünün askerî tedbirlerle olacağını belirtmiştir. Ancak hem hükümet hem de Seraskerlik İsa'ya karşı askerî bir harekât düzenlenmesinin ve bu esnada top kullanılmasının bölgede nasıl bir etki yaratacağını kestiremediği için temkinli davranmıştır. ${ }^{56}$

En nihayetinde 4 Aralık 1902 tarihinde Ferik Şemsi Paşa tarafından Üçüncü Ordu Müşirliğine gönderilen telgrafla taraflar, kısa bir süre için de olsa, rahat bir nefes almışlardır. Gelen telgrafta İsa Bolatinî'nin İstanbul'a gitmek üzere iki adamıyla birlikte trenle Mitroviçe'den ayrıldı̆̆ bildiriliyordu. Önce Selanik'e gidecek olan İsa'nın 6 Aralık'ta Dersaadet'e hareket edecek olan trene binmesi bekleniyordu. ${ }^{57}$ Onun ayrılışından kısa bir müddet sonra 26 Ocak 1903'de Mitroviçe istasyonuna ulaşan trenin yolcuları arasında çiçeği burnunda Konsolos G. S. Scherbiana da bulunuyordu. Başına geleceklerden habersiz bir şekilde trenden inen konsolos, merkezî hükümetin emirleri doğrultusunda saygıyla karşılanarak daha önce hazırlanmış olan eve götürülmüş ve görevine başlamıştır. ${ }^{58}$

İbrahim Hakkı Paşa'ya göre Avusturya-Macaristan İmparatorluğu ile Rus Çarlığı arasında 1903'te Viyana yakınlarındaki Mürzsteg’te gerçekleştirilen ve sonunda Osmanlı Devleti'ne dayatılan programın hazırlandığı mülakatın asıl sebebi İsa Bolatinî idi. ${ }^{59}$ Paşa, 8 Aralık 1910'da Meclis-i Mebusan'da yaptığı konuşmasında konu hakkındaki kanaatini şu şekilde ifade etmiştir:

“... İsa Bolatin Meşrutiyet taraftarıdır demedim ve diyemem değil mi? Sultan Hamid'in o

52 Avlonyalı Ekrem Bey, Osmanlı Arnavutluk'undan Anılar (1885-1912), çev. Atilla Dirim, İletişim Yay., 1. Bask1, İstanbul, 2006 s. 232 (dipnot 10).

53 Arnavutlar arasında "kan kardeşliği” kavramına büyük bir önem verilmiştir. Bir Müslüman ile Hıristiyan kan kardeşliği ilan ederken her iki tarafın kesilen parmaklarından akıtılan birkaç damla kan birer şeker parçasının üzerine damlatılarak karşılıklı olarak yenilirken Hristiyanlar arasında rakı veya şarap içerisine damlatılan kan içilirdi. Böylece kardeşlik akdi gerçekleştirilirken taraflar birbirlerinin kardeşleriyle kardeş, çocukları da birbirleriyle kuzen haline gelmiş ve evlenmeleri kesinlikle yasaklanmıştır. Said Olgun, Arnavut Milliyetçiliğinin Gelişiminde Mektepler, Gece Kitaplığı, Ankara, 2016, s. 49-50.

54 Külçe, Firzovik..., s. 82.

55 BOA, BEO, 1944/145768, H. 02.08.1320 (4 Kasim 1902).

56 BOA, BEO, 1947/145992, H. 08.08.1320 (10 Kasim 1902).

57 BOA, Y.PRK.ASK, 187/77, H. 04.09.1320 (5 Aralık 1902).

58 Kosova Vali Vekili Ferik Ali Rıza'nın 26 ve 28 Ocak 1903 tarihli tezkereleri, BOA, DH.MKT, 531/58, H. 24.06.1320 (28 Eylül 1902). Scherbiana'nın öldürülmesi ve olayla ilgili ayrıntılı bilgi için bk. Saygılı, agm., s. 163-191.

59 Mürzteg Mülakatı ve hazırlanan reform programı hakkında bakınız Ali Dikici, "Osmanlı Makedonya'sında Kurulan İlk Uluslararası Polis Barış Koruma Misyonu: Mürzsteg Reform Programı”, Karadeniz Araştırmaları, C. 6, S. 24 (Kış 2010$)$, ss. 75-108. Gül Tokay, Makedonya Sorunu Jön Türk İhtilalinin Kökenleri (1903-1908), Afa Yay., İstanbul, 1995, s. 74-77. 
kadar nimet ve ihsanını görmüş olan bu adamın yüzünden Makedonya Meselesi (Mürzsteg) mülakatı vuku bulmuş idi. Asıl bu mülakat-1 siyasiyyeye sebep İsa Bolatin idi. O vakit ben de Babıali'de idim. Belki hatırımdadır. Bu İsa Bolatin için Rusya ve Avusturya sefirlerinin Babıali’ye taşındığını gördüm ve söylediler. Böyle meselelere müsaade ediyorsunuz. Bunun altında mühim bir hadise çıkacak dediler. Fakat hamisi vardı. Onun için müsaade zaruri idi. Her şeye dokunabilir ama Hükümetin haddi değil, İsa Bolatin'e dokunamazdı..."

\section{Abdülhamid'in Sadık Bendesi İsa “Bey" Bolatinî İstanbul’da}

Oldukça meşakkatli bir sürecin sonunda yüz liralık yol masrafı dahi Mitroviçe Mal Sandığı tarafından karşılanan İsa Bolatinî Mitroviçe'den uzaklaştırılarak İstanbul'a sevk edilmiştir. ${ }^{61}$ Her ne kadar İsa İstanbul'a gelmiş olsa da akrabalarının Rus konsolosuna bir suikast düzenleyecekleri şayiası devam etmiştir. Bundan dolayı da hükümet, konsolosun güvenliği için askerî ve mülkî tedbirlerin alınmasını istemiştir. ${ }^{62} \mathrm{Ne}$ var ki 31 Mart 1903'te Muhacir İbrahim tarafindan vurulan Konsolos, aldığı yaranın etkisiyle 10 Nisan 1903 'te ölmüştür. ${ }^{63}$

II. Abdülhamid, lütuf ve ihsanlarıyla kendisine ram etmek istediği İsa'yı, "bey" unvanı vererek, Saray muhafızı olarak görev yapan Arnavut Tüfenkçilerin içerisinde istihdam etmiştir. ${ }^{64}$ Buna rağmen İstanbul'da uzun süre durmak istemeyen İsa, sık sık Mabeyn'e giderek bir yandan devlete itaat edeceğine teminat verirken bir yandan da geride bıraktığ 1 ailesinin perişan olduğunu ifade ederek merhamet dilenmekten geri durmamıştır. Bundan dolayı da Mabeyn, Rumeli Müfettişliğinden 29 Mayıs 1903'te Rus yetkililerle görüşülerek Rusya'nın tepkisini çekmeksizin memleketine dönüşünün temin edilip edilemeyeceğine bakılmasını istemiştir. Ancak yapılan görüşmede İsa'nın bölgede bir mütegallibe haline geldiğini, dönüşünün İslam ve Hıristiyan ahalinin emniyetini tehdit edeceğini bu durumun da hükümeti zora düşüreceğini ifade eden Ruslar, İsa'nın dönüşünü uygun görmemişlerdir. ${ }^{65}$ Her ne kadar İsa, ailesinin zor durumda olduğunu ifade ederek Mitroviçe'ye dönme talebinde bulunmuşsa da hem kendisinin hem de ailesinin karşılaştığ 1 zorluklar II. Abdülhamid tarafından giderilmiştir. Öyle ki Padişah, 1318 (1902/1903) yılında iltizam etmiş olduğu aşar bedelinden dolayı var olan 150 liralık borcunun ailesinden, çocuklarından ve akrabalarından talep edilmemesi ve emlakine dokunulmamasını istemiştir. ${ }^{66}$

Gönlü hoş tutularak bir şekilde İstanbul'da kalması sağlanmaya çalışılan İsa, her firsatta memleketine dönmek istediğini belirtirken Yıldız'ın bu konuda en büyük tedirginliği Rusların bunu nasıl karşılayacağını kestirememesinden kaynaklanıyordu. Esasen İsa'yı onların yoğun ısrarları nedeniyle memleketinden uzaklaştırmıştı. 1904 yılı Ekim'inde İsa'nın "iş ve güçle iştigal etmek üzere memleketine avdetine müsaade" edilmesini istemesi üzerine tereddütte kalan Yıldız, Rumeli Müfettişliğinden verilecek iznin bir şikâyete sebep olup olmayacağı yönündeki

60 Meclis-i Mebusan Zabıt Ceridesi, İçtima: 13, 25 Teşrinisani 1326 (8 Aralık 1910), Cilt: 3, s. 472. Aynı bilgi için bkz. Tarık Zafer Tunaya, Türkiye'de Siyasal Partiler, C. I (İkinci Meşrutiyet Dönemi), İletişim Yay., 1. Baskı, İstanbul, 1998, s. 559-560.

61 BOA, BEO, 2301/172528, H. 09.01.1322 (26 Mart 1904). BOA, BEO, 2334/174988, H. 01.03.1322 (16 May1s 1904). BOA, DH.MKT, 864/39, H. 04.04.1322 (15 Haziran 1904). BOA, BEO, 2405/180342, H. 26.06.1322 (7 Eylül 1904).

62 BOA, BEO, 1999/149859, H. 16.11 .1320 (14 Şubat 1903).

63 Sayg1l, agm., s. 177-179.

64 “Albanian Chief”, Saturday Mail, 21 June, 1913, p. 2. Gawrych, age., p. 134. Abdülhamid'in tüfekçi muhafızları hakkında bk. Osman Nuri, Abdülhamid-i Sâni ve Devr-i Saltanat1, Yay. haz. Osman Selim Kocahanoğlu, Temel Yay., İstanbul, 2017, s. 418428.

65 BOA, Rumeli Müfettişliği Sadaret Evrakı (TFR.I.A), 7/645, H. 05.03.1321 (1 Haziran 1903).

66 BOA, Rumeli Müfettişliği Kosova Evrakı (TFR.I.KV), 26/2532, H. 05.04.1321 (21 Temmuz 1903). BOA, BEO, 2283/171175, H. 14.12.1321 (3 Ocak 1904). 
görüşlerini, Rus konsolosunun da fikirleri öğrenilerek, bildirmelerini istemiştir. ${ }^{67}$ Müfettişliğe göre her ne kadar Mitroviçe' deki konsolosluk çalışanları değişmişse de "seleflerinin mesleğini takip etmekte olduklarından” İsa'nın dönüşüne karşı çıkacakları kesindi. Ancak Müfettişlik, dikkat çekici bir öneride bulunarak İsa'dan dönüşünden sonra "k1l ü kal bir harekette bulunmayacağ1 ve şayet Sefaretin müdahalesi üzerine tekrar kaldırılmasına lüzum görüldüğü zaman müşkülat göstermeyerek emre imtisal ile yine Dersaadet'e azimet edeceğini katiyen arz ve temin ederse konsolosların fikirleri sorulmaksızın işlerini muvakkaten tesviye etmek vesilesiyle avdetine müsaade buyurulması" tavsiyesinde bulunmuştur. ${ }^{68}$

$\mathrm{Bu}$ tavsiyeye rağmen Yıldız, ileride bir müşkülata mahal bırakmamak için konu hakkında Rus konsolosunun da fikrinin alınmasını istemiştir. Müfettişlik, "efkâr-1 mutedile" erbabından ve konsoloslar üzerinde tesiri bulunduğuna inandığı "Rusya Sivil Ajanı Demarik" ile konuyu müzakere ederek İsa'nın memleketine dönüşüne müşkülat çıkarmamalarını temin için girişimlerde bulunmuştur. ${ }^{69}$ Ancak yapılan görüşmede Sivil Ajan, İsa'nın bir daha Mitroviçe'ye dönmemesi şartıyla oradan kaldırıldığını, bu hususta kendilerine güvence verildiğini belirterek gelişinden önce hiçbir hadisenin meydana gelmeyeceğine dair bir güvence verilse de Konsolos Scherbiana'nın elim ölümünün zihinlerde çok taze olduğunu, unutulmasını sağlayacak bir süre geçmeden gelmesinin uygun olmayacağını ifade etmiştir. Sivil Ajan, İsa'nın gelmesinin Rusya'nın yeni bir müracaatına ve şikayetine sebep olacağını da sözlerine eklemiştir. ${ }^{70}$

\section{İstanbul'dan Ayrılıșı ve II. Meşrutiyetin İlanına Kadarki Hayatı}

Yıldız, Rumeli Müfettişliği aracılığıyla İsa'nın Mitroviçe’ye dönüşünün Rusya tarafından olumlu karşılanmayacağını öğrenmiş olmasına rağmen ona memleketine dönmesi için izin vermekten geri durmamıştır. Bazı işlerini düzene koymak üzere memleketine gitmesine izin verilen "Mitroviçeli İsa Bey", 21 Şubat'ta Yıldız'a gitmiştir. Burada ona "ahali-i sadıkayı ihtilal ve ifsad eden" kötü niyetli yabancıların entrikalarına kapılmaması, sadakatten ayrılmaması ve herhangi bir şikâyete meydan vermemesi tembih edilmiştir. Ayrıca İsa’ya Hazine-i Hassa-i Şahaneden iki bin; Rumeli Vilayetinden de bin kuruş olmak üzere üç bin kuruş maaş tahsis ve ihsan buyurulmuştur. ${ }^{71}$

Geçmişte Abdülhamid, İsa’ya Hıristiyan ahaliyi eşkıyanın zulmünden koruduğu için köyü civarındaki değirmen taşı ocakları hasılatının bir miktarını vermişti. ${ }^{72} \mathrm{Bu}$ kez daha büyük bir lütufta bulunarak 19 Mart 1905'te, köyünde bulunan değirmen taşı madenini işletme imtiyazını ihsan etmiştir. ${ }^{73}$ Abdülhamid'in İsa'ya ihsanı bununla sınırlı kalmamıştır. 16 Şubat 1905 'te kendisine

67

68

69

70

71

Şevket, 6 Mart 1906'da Rumeli Müfettişliğine gönderdiği bir yazıda “işbu bin kuruş maaşın nereden ita” buyrulacağını Hasan'a üç yüzer kurus maas verilmesi kararlaștırıldığı halde o güne değin bir tebligat yapılmadığına dair 16 Nisan 1906 tarihli yazısı. BOA, TFR.I.MKM, 17/1654, H. 23.07 .1324 (12 Eylül 1906). Maaşıla ilgili diğer yazışmalar için bkz. BOA, DH.MKT, 1116/27, H. 23.07.1324 (12 Eylül 1906). BOA, Rumeli Müfettişliği Arzuhaller (TFR.I.ŞKT), 105/10404, H. 17.12 .1324 (1 Şubat 1907).

72 Taş ocağı hasılatının bir kısmının İsa'ya verildiği ve bu durum karşısında taş ustalarını birtakım şikayetleri hakkında bk. BOA, TFR.I.KV, 75/7458, H. 17.08.1324 (27 Ekim 1904).

73 BOA, Irade Orman ve Maadin (I.OM), 10/25, H. 12.01.1323 (19 Mart 1905). BOA, BEO, 2530/189723, H. 13.01.1323 (20 Mart 1905). BOA, BEO, 2663/199694, H. 10.07.1323 (10 Eylül 1905). BOA, BEO, 2688/201536, H. 19.08.1323 (19 Ekim 
Üçüncü Rütbeden Osmanî Nişanı ${ }^{74}$ verilirken ailesinin de gönlünün alınması düşüncesiyle olsa gerek aynı gün annesi Ayşe Hanım'a İkinci Rütbeden Şefkat nişanı verilmiştir. ${ }^{75} 22$ Şubat'ta çıarılan bir iradeyle eşleri Kamile ve Hamide hanımlarla kızı Azize Hanıma İkinci Rütbeden Şefkat Nişan-1 Hümayunu ihsan buyurulmuştur. ${ }^{76}$ Aynı şekilde adamları Priştineli Haşim ve İpek Sancağının İstenik nahiyesinden Hasan Ağaların da 300'er kuruş maaşla zabıta işlerinde istihdam edilmesi kararlaştırılmıştır. ${ }^{77}$

İsa'nın Mitroviçe'ye dönüşünden haberdar olan Rus hükümeti, Petersburg'da bulunan Osmanlı Sefirine bir nota vererek şiddetli bir tepki göstermiştir. Rusya Dışişleri Bakanlığının vermiş olduğu notada kötü şöhretiyle tanındığını belirttikleri İsa'nın Arnavutların sakin olduğu havaliden uzaklaştırılmasında ısrarlı olduklarını ifade edip konunun iki devlet arasındaki mevcut iyi ilişkileri ihlal edebilecek bir meseleye dönüşmeden neticelendirilmesini istemişlerdir. ${ }^{78}$ İstanbul'dan hareket eden İsa, 23 Şubat'ta Selanik'e ulaşmıştır. ${ }^{79} \mathrm{Bu}$ arada Sadrazamı ziyaret eden Rusya Sefareti Baştercümanı Malikof, iki gün içerisinde Mitroviçe'ye ulaşacak olan İsa'nın Arnavutluk'un bazı yerlerinde görülen "galeyan-1 efkâr" sebebiyle orada bulunmasının kargaşaya sebebiyet vereceği düşüncesindedir. ${ }^{80}$

Rusya'nın tüm karşı çıkışlarına rağmen İsa'nın arkasında duran Yıldız, çıkarılan afv-1 umumi ile hırsızlık ve eşkıyalık yapanlar hatta gemilere ve trenlere dinamit atarak nice insanın ölümüne sebep olanlar dahi memleketlerine dönmüş iken onun dönememesinin adaletsizlik olacağı görüşündedir. İsa'nın Mitroviçe'ye dönüşünden önce birtakım nümayişler olmuşsa da bunların bertaraf edilmiş olması, İsa'nın "nesayihede istahdam olunarak hidmet-i sadakatkaranede" bulunduğunun Ferik Şemsi Paşa tarafından bildirilmesi Yıldız'ın elini Rusya'ya karşı güçlendirmiştir. Bundan dolayı da hem bir yanlış anlaşılmaya sebebiyet vermemek hem de İsa hakkında yeni bir müracaata mahal bırakmamak için gerekli tedbirlerin alınması istenmiştir. ${ }^{81}$ Yıldız'ın Rusya'ya karşı İsa'nın arkasında durmasının asıl nedeni onun bölgedeki Arnavutlar üzerindeki tesiri olması ihtimali oldukça kuvvetlidir. Çünkü, o günlerde Arnavutlar arasında bir kargaşa çıkması için dışarıdan birtakım teşebbüslerde bulunulduğu haber alınmıştır. Bunun üzerine alınan birtakım tedbirler çerçevesinde Müslümanların ileri gelenlerinin halka nasihatte bulunması düşünülürken "bazı işlerini tesviye etmek üzere muvakkaten” o tarafa giden İsa'nın da bu yolda Rumeli Müfettişliğinin vereceği talimata göre hareket etmesi kararlaştırılmıştır. Öyle ki Yıldız, konu hakkında Hüseyin Hilmi Paşa'yı bilgilendirirken onun "hidemat-1 sadakatte" bulunacağını ifade ettiği gibi saldırılardan da korunmasını istemiştir. ${ }^{82}$ İstanbul'dan dönüşünde Rumeli Müfettişi Hüseyin Hilmi Paşa'dan gördüğü “hüsn-i iltifat ve teattufat" nedeniyle pek memnun olan İsa, 19 Mart’ta Paşa'ya gönderdiği bir mektupla şükranlarını ifade ettiği gibi "tevafür-i şan ve tekasür-i ömr ü ikbal-i devlet" duasında

1905). BOA, BEO, 2692/201864, H. 25.08.1323 (25 Ekim 1905). BOA, BEO, 2697/202274, H. 03.09.1323 (1 Kasım 1905). BOA, BEO, 2724/204248, H. 23.10 .1323 (21 Aralı 1905). BOA, Y.PRK.A, 14/14, H. 24.10.1323 (22 Aralık 1905). Madenin işletilmesi esnasında çıkan problemler için bk. BOA, TFR.I.KV, 154/15327, H. 07.01.1325 (20 Şubat 1907).

74 BOA, Irade Taltifat (İTAL), 358/20, H. 11.12.1320 (16 Şubat 1905).

75 BOA, I.TAL, 358/30, H. 11.12 .1320 (16 Şubat 1905).

76 BOA, I.TAL, 386/20, H. 28.12.1323 (23 Şubat 1906).

77 BOA, TFR.I.MKM, 17/1654, H. 23.07.1324 (12 Eylül 1906).

78 BOA, Y.A.HUS, 500/80, H. 14.01 .1323 (21 Mart 1905).

79 BOA, TFR.I.A, 30/2966, 14.04.1324 (10 Haziran 1906).

80 BOA, Y.A.HUS, 499/129, H. 30.12 .1323 (25 Şubat 1906).

81 BOA, I.HUS, 139/40, H. 15.01.1324 (11 Mart 1906). BOA, HR.SYS, 118/28, M. 16.03.1906.

82 BOA, TFR.I.A, 30/2966, H. 14.04.1324 (10 Haziran 1906). 
da bulunmuştur. ${ }^{83}$

Artık devlethizmetine giren İsa, Yıldız'a gönderdiği mektuplarla bölgedeki gelişmeler hakkında bilgi vermeye başlamıştır. Öyle ki verdiği bilgilerin mahremiyetine o kadar inanmaktadır ki bu tarz bilgileri telgrafla sunmak üzere bir şifre miftahının da kendine "ihsan" buyurulmasını istemiştir. ${ }^{84}$ 30 Mart 1906 tarihinde kaleme aldığı mektubunda bölgenin genel durumu hakkında bilgi verirken Avusturya'nın Mitroviçe'deki konsolosu aracılığıyla Arnavutlara para dağıtarak halkı fesada sürükleyerek bir ihtilal çıkarmaya çalıştığından bahsetmiştir. Ancak İsa’ya göre başarılı olmaları mümkün değildir çünkü hem Arnavutlar Padişaha sadakatle bağlıdırlar hem de kendisi onların "teşebbüslerini akim bırakmak hususunda son derece çalışıyor ve muvaffak" oluyordu. Bununla birlikte Prizren ahalisinden Bekir Bin Molla Fazlı'nın Prizren'deki Avusturya konsolosundan her ay sekiz Fransız altını maaş alarak ona Arnavutluk'taki durum hakkında bilgi verdiği gibi "bir takım uygunsuzluğun zuhuruna" çalıştığını ihbar etmiştir. İsa'nın bir diğer ihbar ettiği kişi Mitroviçe Kaymakamı olmuştur. Ona göre kaymakam "sadık bendegan-ı saltanat-1 seniyyeden" değildi ve Padişahın rızası dışında bir olayın meydana gelmesine sebebiyet verecekti. ${ }^{85}$ Mabeyn Başkatibi Tahsin Paşa, İsa'nın memleketine dönüşünden sonra Yıldız'a gönderdiği telgrafındaki halkın Padişaha sadakatle bağlı olduğuna yönelik ifadelerinin Abdülhamid tarafından hiç de önemsenmediğini belirtmiştir. Ona göre İsa'nın verdiği güvence kuru bir sözden ibaretti. Öyle ki İsa'ya bu telgrafın, onun Yıldız nezdinde muteber olduğunu bilen, İttihat ve Terakki Cemiyeti tarafından siyasî bir entrikayla çektirilmiş olabileceğini de ifade etmiştir. ${ }^{86}$

Bölgedeki Rus konsolosları, memleketine dönen İsa'yı ve faaliyetlerini pürdikkat bir şekilde takip etmeye başlamışlardır. Kosova Valisi Mahmud Şevket Paşa'yı ziyaret eden Üsküp'teki Rusya konsolosu Blayof, İsa'nın hükümet işlerinde istihdam edildiği ve Arnavutların teskini için bir aracı olduğu yönünde bazı rivayetlerin bulunduğunu belirttikten sonra Selanik'te ikamet edeceği duyulan İsa'nın birkaç gün önce Üsküp'e gelerek vilayetten bazı emirler aldığını ifade etmiştir. Mahmud Şevket Paşa, konsolosa İsa'nın dönüşünün yüzüstü kalan işlerini düzene sokmak amacıyla olduğunu, hükümet işlerinde istihdam edildiğine dair haberlerin gerçek olmadığını, Üsküp'e tasarrufunda bulunan bir çiftlik hakkında açıklama yapması için çağırıldığını ifade ederek durumu kotarmaya çalışmıştır. ${ }^{87}$

Benzer bir şikâyet Avusturya Sefareti tarafindan 24 Nisan 1906'da Hariciye Nezaretine iletilmiştir. Avusturya'nın Mitroviçe'de bulunan konsolosuna göre İsa, hemşerilerini kanunsuzluğa teşvik ettiği gibi haklarında adli soruşturma başlatılan kişileri de himaye etmekteydi. İsa'nın memleketine dönüşüyle birlikte silah taşıma yasağına riayetin ortadan kalktığını ifade eden konsolos, silahlı Arnavut çetelerinin askerî ve mülkî memurların herhangi bir müdahalesi olmaksızın şehir ve çevresinde dolaşabildikleri ifade etmiştir. Öyle ki "eşkıya ve diğer erbab-1 ceraim” de serbestçe dolaştıkları gibi bölgedeki askerî ve mülkî memurların bilgisi dahilinde İsa ile görüşmektedirler ve hiç kimse bunları yakalamaya dahi cesaret edememekteydi. Sefaretin bildirdiğine göre konsolos bu hale bir nihayet verilmesi için teşebbüste bulunmuşsa da bir netice alması mümkün olmamıştır.

83 BOA, Rumeli Müfettişliği Müteferrika Evrakı (TFR.I.M), 11/1025, H. 23.01.1324 (19 Mart 1906).

84 BOA, TFR.I.A, 30/2947, H. 23.03 .1324 (17 May1s 1906). Gawrych, İsa Bolatini'nin Mitroviçe'ye döndükten sonra “deruhdecilik" olarak tabir edilen Gayrimüslimlerin koruyuculuğuna devam ettiğini, bu iş için Sırbistan'dan para ve silah aldığını ifade eder. Ayrıca İsa'nın Sultanın polisi gibi hareket ettiğini Yıldız’la doğrudan görüşebildiği bir telgraf hattının varlığından bahseder. Gawrych, age., s. 134.

85 BOA, TFR.I.A, 30/2947, H. 23.03.1324 (17 May1s 1906).

86 Tahsin Paşa, age., s. 398-400.

87 BOA, TFR.I.MKM, 17/1654, H. 23.07.1324 (12 Eylül 1906). 
Zaten müracaat ettiği ve görüştüğü memurlar da İstanbul'dan özel bir emir gelmedikçe bir şey yapamayacaklarını ifade etmişlerdir. Sefaret, bölgede bozulan asayişin yeniden tesisi için İsa'nın Arnavutların meskûn olduğu bölgenin dışına çıkarılması gerektiğini özellikle belirtmiştir. ${ }^{88}$ Sefaretin tüm bu iddiaları üzerine Sadaretin talebiyle Rumeli Müfettişliğince bir soruşturma başlatılarak iddiaların aslının olup olmadığ 1 araştırılmıştır. ${ }^{89}$ Kısa süre içerisinde tamamlanan tahkikatla bölgede asayişin berkemal olduğu tespit edilirken halkın kanunsuzluğa teşvik edildiği, kasabada çetelerin ve İsa'nın kalabalık gruplar halinde silahlı dolaştıkları iddialarının asılsız olduğu belirlenmiştir. ${ }^{90}$ Ancak tahkikatı yapan memurun 5 Mayıs tarihli bu raporundan bir gün sonra Kosova Valiliği tarafından Sadarete gönderilen bir yazı, iddiaları doğrular niteliktedir. Yazıda İsa'nın bir takım kanun kaçaklarıyla görüştüğü ancak bunun pek de önemsenmediği hatta adamlarından silahla gezenlerin de olduğu ifade edilmekteydi. Hatta yazıda silahla gezecek adamları için usulen silah tezkeresi almaları yönünde telkinde bulunularak gelebilecek itiraz ve şikayetlerin önüne geçilmeye çalışıldı̆̆ 1 ifade edilmiştir. ${ }^{91}$

Öteden beri İsa'nın bölgedeki varlığından en fazla rahatsızlık duyan ülke Rusya olmuştur. Yıldız'ın Rusya'nın onun hakkındaki kanaatini değiştirmek için yaptığı plan dönemin genel politikasına oldukça uygundur. İsa'nın 30 Mart'ta kaleme aldığı mektubunda Avusturya'nın bölgedeki faaliyetlerinden bahsetmesi üzerine Yıldız, onun Rusya Konsolosuyla görüşerek bu bilgileri onunla paylaşmasının ve ileride de Avusturya'nın teşebbüsleri hakkında bilgi vereceğini söylemesinin uygun olacağını bildirmiştir. Yıldız'a göre bu görüşme Rusların onun hakkındaki düşüncelerini olumlu yönde değiştirecekti. ${ }^{92}$ Ancak daha gerçekçi düşünen ve hareket eden Rumeli Müfettişi Hüseyin Hilmi Paşa, hakkında arka arkaya gelen şikayetler nedeniyle İsa'nın Rus konsolosuyla görüşmesinin uygun olmayacağını ifade ederek karşı çıkmıştır. ${ }^{93}$

Ardı arkası kesilmeyen şikayetler ile İsa'nın bölgeden uzaklaştırılması yönündeki talepler karşısında daha fazla direnemeyen Yıldız, durumu idare etmek için yeni bir çözüm yolu bulmuştur. 17 Mayıs 1906'da Rumeli Müfettişliğine gönderilen bir emirle İsa'nın bir iki ay sonra memleketine dönmek üzere Selanik'e çağırılması ve burada meşgul edilmesi istenmiştir. Ancak sızlanmasına asla meydan verilmemesine ve Selanik'e çağırılmasının nedenini anlamamasına özen gösterilmesi gerekiyordu. ${ }^{94}$ Müfettişlik, Yıldız'dan aldığı emre istinaden "bazı hususatı müzakere” etmek için İsa'yı Selanik'e çağırmıştır. Hüseyin Hilmi Paşa, memleketinden uzaklaştırılan İsa'nın bir müddet sonra durumdan şüpheleneceğinden ve Selanik'e niçin çağırıldığını sorgulamaya başlayacağından emindir. Bu yüzden iskân ve idaresine çare kalmadığı zaman Yıldızın emriyle orada bulunduğunu söylemeksizin aleyhindeki şikayetleri tekzip amacıyla bir müddet birlikte bulunmalarına lüzum gördüğünü bunun onun için daha hayırlı olacağından bahsederek geçiştirmeyi düşünmüştür. ${ }^{95}$

Genel olarak İsa'nın Arnavutluk’tan uzaklaştırılmasını adil bir uygulama olarak görmeyen ve uygulamanın Arnavut kanaat önderlerini hükümetten soğutarak yabancılarla yakınlaşmalarına vesile olacağını düşünen Hüseyin Hilmi Paşa, ${ }^{96} 31$ Mayıs’ta Yıldız'a 23 Mayıs'tan beri Selanik’te 
ikamet ettirilen İsa'nın bir hafta sonra Mitroviçe'ye dönmesine izin verilmesinin münasip olacağını bildirmiştir. ${ }^{97}$ Bunun üzerine 3 Haziran'da İsa’nın “bazı tarafın umurperverini okşamak” ve "def-i şikâyet” amaciyla Selanik’te devam eden zorunlu ikametine son verilmesine karar verilmiştir. Her zaman olduğu gibi İsa’ya şikayetlere meydan vermemeye özen göstermesi ve devlete sadakatle hizmet etmeye devam etmesi telkininde bulunulması da Yıldız tarafından özellikle istenilmiştir. On iki gündür Selanik'te bulunan İsa, tüm bu olup bitenlerden habersiz bir şekilde memleketine dönmesine izin verilmesinden bir gün sonra 4 Haziran'da Hüseyin Hilmi Paşa’yı ziyaret ederek artık gitmek istediğini söylemiştir. Müfettiş Paşa, konuşulacak ve müzakere edilecek bazı konuların olduğunu söyleyerek 7 Haziran'a kadar sabretmesini istemiş zor da olsa birkaç gün daha kalmaya ikna edebilmiştir. Aynı gün Rusya Sivil Ajanıyla görüşen Hüseyin Hilmi Paşa, İsa'nın o güne değin hiçbir yolsuzluğa karışmadığını bundan sonrada karışmayacağını, en ufak bir hatası görülürse her türlü mesuliyetin kendine ait olduğunu ifade ederek ona kefil olmuştur. Paşa, Rusya'nın bu konuda daha fazla ileri gitmesinin dostluğa uygun olamayacağını da beyan etmiştir. ${ }^{98}$

Gerekli nasihatte bulunulduktan sonra Selanik’ten yolcu edilen İsa, önce Üsküp'e oradan da memleketi Mitroviçe'ye ulaşmıştır. ${ }^{99}$ Ancak yolda yaşadığı bir hadise canının çok sıkılmasına sebep olmuştur. Esasen onu üzen hadise İsa'nın ne derece şımarmış olduğunu da gözler önüne sermiştir. Gördüğü izzet ve ikramdan gayet hoşnut ${ }^{100}$ Selanik’ten neşe içerisinde ayrılmış keyifle yolcuğunun sonuna yaklaşan İsa ve beraberindeki altı adamı trenle Vulçitrin'e ulaşmışlardır. Buradan Mitroviçe’ye doğru yola çıktıklarında kasabadaki eski kale civarında üç bin iki yüz mavzer ile altı yüz kırk sandık mühimmatın bulunduğu cephanenin yanından ellerindeki mavzer ve martini tüfeklerle geçmek üzerelerken durumlarında şüphelenen ve kim olduklarını bilmeyen nöbetçiler tarafından geçişlerine izin verilmeyerek bir başka yola yönlendirilmişlerdir. Kendisini tanıtıp silahla gezmesine izin verilmiş olduğunu söylemesine ve hatta orada bulunan bir çavuş tarafından teşhis edildiği halde geçmelerine müsaade edilmemesine içerleyen ve kızan İsa, 8 Haziran'da Rumeli Müfettişliğine gönderdiği bir telgrafla yapılan bu muameleden şikayetçi olmuştur. İsa'nın gördüğü izzet, ikram, ihsan ve lütuf nedeniyle şımardığının bir göstergesi olarak nitelendirilebilecek telgrafta askerle çatışmaya sadakatinin mâni olduğunu, kendisine her yerde silahlı gezmeye izin verildiği halde bu muamelenin kimin emriyle yapıldığını öğrenmek istediğini belirttikten sonra "bu işin yarına kadar icrasına bakılmazsa" Padişaha arz edeceğini ifade etmiştir. Vulçitrin Kaymakamı Hasan Celil ile de görüşen İsa, Müfettişliğe müracaatının gerekçesini yaşadığ bu hadisenin herhangi biri tarafından yapılan teşvik neticesinde olup olmadığını öğrenmek olarak ifade etmiştir. ${ }^{101}$ Ancak Hüseyin Hilmi Paşa, telgrafın içeriğini "yolsuz" şikâyeti de "haksız" olarak nitelendirmiştir. ${ }^{102}$

Tespit edilebilen bilgi ve belgeler ışı̆̆ında yapılacak bir değerlendirmeyle İsa'nın 1906 yılının ikinci yarısından itibaren şahsi menfaatlerini korumak ve artırmak için gayret sarf ettiği bunu da temin edebilmek için Yıldız'a, Rumeli Müfettişliğine ve yerel hükümete yaranmaya çalıştığ ifade edilebilir. II. Meşrutiyetin ilanına giden süreç içerisinde bozulmaya başlayan ilişkiler, II. Meşrutiyetin ilanından sonra bir çatışmaya dönüşmüştür.

97 BOA, TFR.I.A, 30/2958, H. 07.04.1324 (31 Mayıs 1906).

98 BOA, TFR.I.A, 30/2966, H. 17.04 .1324 (10 Haziran 1906).

99 BOA, TFR.I.A, 30/2966, H. 17.04.1324 (10 Haziran 1906).

100 BOA, TFR.I.ŞKT, 89/8842, H. 18.04.1324 (11 Haziran 1906).

101 BOA, Rumeli Müfettişsliği Jandarma Müssiriyet ve Kumandanlı Evrakı (TFR.I.AS), 35/3450, H. 16.04.1324 (9 Haziran 1906). 102 BOA, TFR.I.A, 30/2966, H. 17.04.1324 (10 Haziran 1906). 
İsa, 7 Kasım 1906'da Rumeli Müfettişliğine göndermiş olduğu bir yazıda sarhoş gezdiğini söylediği Mitroviçe kaymakamının devlet ve memleket işlerine önem vermediğini bu yüzden de halkın değiştirilmesi talebiyle Padişaha müracaat etmek istediklerini ancak kendisinin bu durumu öncelikle Müfettiş Paşa'ya bildirmek için buna mâni olduğunu ifade etmiştir. İsa, saltanata sadakati bulunmadığını söylediği kaymakamın görev süresinin uzamasının hükümetin başına büyük bir gaile açmasından korktuğunu, halkın kaymakamın değiştirilmesi için kıyam edebileceğini bunun da uygunsuz birtakım hadiselere sebebiyet verebileceğini belirttikten sonra bu tarz olayların yaşanmasını istemeyeceğini düşündügü Hüseyin Hilmi Paşa'dan gerekenin yapılmasını talep etmiştir. İfadeleri ve talebi dikkate alındığında İsa'nın kaymakamın uygunsuz hareketleri nedeniyle çıması muhtemel bulunan olayların önüne geçmek niyetinde değil daha çok kaymakamın değiştirilmesini aksi takdirde halkı ayaklandıracağı tehdidinde bulunduğu düşünülebilir. ${ }^{103}$ İsa'nın hakkında şikâyette bulunduğu bir başka kişi Selanik’te yayımlanan Yeni Asır gazetesi muhabiri İsmail Hakkı Efendi olmuştur. Velinimeti hakkında layık olmayan sözler söyleyenlerin ağızlarını kapatmanın en önemli vazifesi olduğunu belirten İsa, 20 Şubat 1907'de Y1ldız'a gönderdiği bir yazıda Selanik'ten yola çıkan İsmail Hakkı'nın Mitroviçe’ye gelinceye kadar her uğradığı yerde Padişah hakkında münasebetsiz sözler söylediğini, yakalanarak tutuklanması için Mitroviçe kaymakamlığına ihbarda bulunduğunu ancak henüz yakalanmadığını ifade etmiştir. ${ }^{104}$

Her ne kadar İsa, Yıldız nezdinde saltanata ve devlete sadakatinden şüphe edilmeyecek bir bende imajı oluşturmaya çalışsa da bölgedeki askerî ve mülkî idareciler nezdinde hakkındaki intiba çok da olumlu değildi ve her geçen gün daha da bozuluyordu. Bu noktada Kosova Valisi Mahmud Şevket Paşa ile Rumeli Müfettişi Hüseyin Hilmi Paşa arasında 1907 yılının Mart ve Nisan aylarındaki yazışmalarda bu durum oldukça belirgindir. Yazışmalarda yanına topladığı Zeynullah, Balya Ağa, Haşim, Ala ve İbrahim isimlerindeki kişilerle asayişi bozacak bir eylemde bulunmasından endişe edilirken eğer böyle bir ahval ve hareketi söz konusu olursa aymazlık gösterilmemesi gerektiği üzerinde durulmuştur. ${ }^{105}$

İsa hakkındaki şikayetler çoğu zaman uygunsuz hareketleri nedeniyle Sefaretlerce yapılmaktaydı ve bunlar bir şekilde geçiştirilmekteydi. Ancak artık İsa'nın Osmanlı ülkesine iltica etmiş kimsesiz yetimlere ait mal ve mülkü gasp ettiği, öteden beri kanun kaçaklarını yanında barındırdığı, sekiz - on silahlı adamıyla dolaştığ ve kendisine yapılan nasihatlere kulak asmadığ şeklindeki şikayetler hem halk hem de bölgedeki mülkî erkan tarafından sıkça dile getirilmeye başlanmıştır. Özellikle İsa'nın kanun kaçaklarını muhafaza etmesi, adliyeye sevk edilmek istenilirken Yıldız'dan gönderilen bir yazıyla "mahkemeye celbinden sarf-1 nazar" edilmesinin istenmesi onun her geçen gün biraz daha şımarmasına sebep olmuştur. İsa'nın kanun tanımaz tavrı ve Yıldız'ın ona yaklaşımı hem Ferik Şemsi Paşa'yı hem de Kosova Valisi Mahmut Şevket Paşa'yı daha büyük bir gailenin ortaya çıkması hususunda endişelendirmiştir. ${ }^{106}$

Sultan II. Abdülhamid'in lütuf ve ihsanına mazhar olan İsa Bolatinî, bunun karşıllğıını Sultana olan sadakatinin yanı sıra sunduğu hediyeyle de göstermek istemiştir. Kendisi tütün kullanan, huzuruna kabul ettiği devlet erkanına da ikram eden hatta Boer Savaşı esnasında İngiliz askerleri için İngiltere'ye tütün göndermiş olan Sultan II. Abdülhamid için en anlamlı hediyenin tütün olacağını düşünen Bolatinî, 1907 yılının Eylül ayında bir buçuk kıyye ağırlığında 30 kuruş değerinde bir

103 BOA, TFR.I.ŞKT, 100/9937, H. 20.09.1324 (7 Kasım 1906).

104 BOA, Yıldız Esas Evrakı (Y.EE), 15/209, H. 07.01.1325 (20 Şubat 1907).

105 BOA, TFR.I.KV, 158/15799, H. 09.03.1325 (22 Nisan 1907).

106 BOA, TFR.I.A, 34/3327, H. 09.04.1325 (22 May1s 1907). 
kutu tütünü Padişaha hediye olarak göndermiştir. ${ }^{107}$

1908 yılının başında Avusturya demiryolu hattının Bosna'dan Mitroviçe'ye kadar uzatılmasını öngören eski bir plan tekrar gündeme gelmiştir. Aynı günlerde Sirp hükümeti, Kosova ile Kuzey Arnavutluk'tan geçerek Adriyatik'e uzanacak bir plan üzerinde duruyordu. ${ }^{108} \mathrm{Bu}$ durumu bir firsata dönüştürmek isteyen İsa, 13 Nisan 1908'de Yıldız'a bir mektup göndermiştir. Abdülhamid nezdindeki itibarını artırmak düşüncesiyle yazdığı mektubunda halk arasında Avusturya'nın demiryolu hattını Mitroviçe'ye kadar uzatacağı diğer taraftan Sırbistan ve yabancı devletlerin dahi o yolda girişimlerde bulunacakları böylece Arnavutluk'u ablukaya almak amacında oldukları hatta bunun için mühendisler geleceği yönünde iddiaların konuşulduğunu ifade etmiştir. Mektubunda mühendislerin gelişine engel olmayı düşündüğünü ancak Padişaha haber vermeksizin böyle bir teşebbüste bulunmaya cesaret edemediğini, Padişahın inşa olunacak demiryoluna izin verdiğine dair bir irade gelmedikçe buna itimat edemeyeceklerini belirtmiş eğer Padişahın hattın inşasına rızası varsa Padişahın kurbanı olduğunu, onun işlerini bilmeye ve işlerine müdahaleye kıyam etmek gibi düşüncesinin olamayacağını ifade etmiştir. ${ }^{109}$

\section{Meşrutiyetin İlanından Sonraki Hayatı, Arnavut İsyanlarındaki Faaliyetleri}

Meşrutiyetin tekrar ilan edilmesi için II. Abdülhamid'e karşı uzun süredir devam eden muhalefet hem iç hem de dış politikada yaşanan gelişmelerle Sultanı her geçen gün biraz daha köşeye sıkıştırmıştır. Makedonya' daki İttihatçı subaylar, asker arasında ihtilal propagandası yaparken aynı zamanda onları Sultanın memleketi sattığına inandırıyorlardı. Birçok resmî dairenin başında bir yabancının bulunması bu yöndeki kanının en büyük sebebiydi. Bir yandan Almanların hızlı bir şekilde Anadolu topraklarında ilerleyerek Bağdat hattı boyunca nüfuz bölgelerini genişletmeleri bir yandan Avusturya-Macaristan İmparatorluğu'nun Uzice-Mitroviçe demiryolu hattıyla Kosova'nın iç kesimlerine ilerlemesi tehlikesi, öte yandan Büyük Güçlerin Girit'ten askerlerini çekerek adanın Yunanistan ile birleşmesinin yolunu açmaları ihtimali endişeleri artırmıştır. 10 Haziran 1908'de Reval'de Rus Çarı ile İngiltere Kralının buluşması bu tehditleri artırırken orduyu isyana teşvik etmiştir. Bunun sonucunda Resneli Ahmet Niyazi ile Enver dağa çıkmışlardır. Selanik'te II. Abdülhamid'in adamları kurşunlara hedef olurken askerler de silahlarını bırakıp terhis talebinde bulunmaya başlamışlardır. Umutsuzluğa kapılan Abdülhamid, isyanı Arnavutlar aracılığıyla bastırmayı düşünmüştür. Bu doğrultuda Mitroviçe'de bulunan 18. Firka Kumandanı Ferik Şemsi Paşa, Firzovik’te büyük bir kitle toplamıştır. İttihatçılar, toplanan bu kitleyi Miralay Galip Bey aracılığıyla amaçlarının ülkeyi Avrupa'nın müdahalesinden kurtarmak olduğunu eğer gerçekleştirebilirlerse bu durumun Arnavutların da lehine olacağını söyleyerek onları da yanlarına çekmeyi başarmışlardır. Böylece Abdülhamid Firzovik’te kendi silahı Arnavutlarla vurulmaya başlanmış onlar da meşrutiyet talebinde bulunmaya başlamışlardır. Ancak buna İsa Bolatinî karşı çıkmıştır. ${ }^{110}$

21 Haziran 1913 tarihli Saturday Mail gazetesinde yer alan bir makalede İsa'nın İttihatçıların meşrutiyetin şeriat, tam özgürlük ve adem-i merkeziyeti ifade ettiği yönündeki propagandasıyla

107 BOA, Yıldız Perakende Evrakı Arzuhal Jurnal (Y.PRK.AZJ), 53/16, H. 08.08.1325 (16 Eylül 1907).

108 Malcolm, age., s. 293.

109 BOA, Y.PRK.AZJ, 54/12, H. 09.03.1326 (11 Nisan 1909).

110 Aram Andonyan, Balkan Savaşı, çev. Zaven Biberyan, Aras Yay., 2. Bask1, İstanbul, Ekim 2002, s. 158. Necmettin Alkan, Mutlakıyetten Meşrutiyete II. Abdülhamid ve Jön Türkler, Selis Kitaplar, 1. Bask1, İstanbul, 2009, s. 211-231. “Galip Paşa'nın Hâtıraları", Hayat Tarih Mecmuası, Y11: 2, C. 1, S. 6 (Temmuz 1966), s. 8-11. 
meşrutiyet talebi aldatmacalarına kapılmadığını belirterek Firzovik’te bulunmaktan imtina ettiğini ifade ettiği yönünde bir bilgiye yer verilmiştir. ${ }^{111}$ Ancak Süleyman Külçe'ye göre Firzovik'e çağrılan davetliler arasında bulunan İsa, Mitroviçe'den Firzovik'e gelmiş Said Hüseyin'in evinde misafir olmuştur. "İsa evvela, buradan başlayarak tanıdıklarına mütemadiyen Padişah babanın yüksek siyaset ve bilgisinden ve büyük devletler arasındaki müstesna mevkiinden bahsederek memleketi şahsında temsil eden peygamber vekilinin incitilmemesini ve rivayetlere kapılarak yanlış yola gidilmemesini tavsiye" etmiştir. ${ }^{112}$ II. Abdülhamid tarafından hususi bir şifre ile meselenin Yıldız lehine halline memur edilen İsa, o sırada hasta kızının vefatı üzerine Mitroviçe'ye dönmek zorunda kalmıştır. Elindeki Mabeyn şifresi ile Padişaha kızının cenaze işlemleri tamamlandıktan sonra tekrar Firzovik'e dönüp "rıza-yı aliye mutabık harekette bulunacağını" bildirmişse de o geri dönmeden Galip Bey, Meşrutiyetin ilanı noktasındaki faaliyetlerini başarılı bir şekilde tamamlamıştır. ${ }^{113} 20$ Temmuz 1908'de Firzovik'ten Padişaha hürriyet ve Kanun-i Esasi'nin iadesi talebini içeren bir telgraf gönderilmiştir. Külçe'ye göre Padişahın bu talebe 22 Temmuz'a kadar cevap vermemesinin nedeni, öldürülen Şemsi Paşa'nın yerine atanan Tatar Osman ve İsa Bolatinî’nin bu meseleyi çözeceğine olan inancıyd1. ${ }^{114}$ Ancak güvendiği dağlara birer birer kar yağan II. Abdülhamid, 23 Temmuz'da Kanun-i Esasi'nin iadesini kabul etmek zorunda kalmıştır. ${ }^{115}$

"Bir dağ haydudu" 116 iken hem kendisi hem de ailesi II. Abdülhamid'in bol maaş, rütbe ve ihsanlarıyla gönlü hoş tutulan İsa'nın ${ }^{117}$ Jön Türklerle ilişkileri her geçen gün bozulmuştur. Meşrutiyetin ilanından on gün sonra 4 Ağustos'ta Priştine Mutasarrıf Vekili Cemal Bey, Rumeli Müfettişliğine gönderdiği yazısında Kanun-i Esasi'nin ilanından dolayı şahsi menfaatleri ve gayrimeşru işleri zarar gören İsa'nın Vulçitrin kazasında gizli bir şekilde dolaşarak meşrutiyet idaresi ve Kanun-i Esasi aleyhinde çalıştığı yönünde ihbar alındığını bildirmiştir. Söz konusu ihbar her ne kadar teyit edilememiş olsa da rejimin meşrutiyete inkılabının birçok kişiyi müteessir ettiği bir gerçekti. Bundan dolayı da yeni rejimin muhaliflerine karşı teyakkuzda olunması ve tedbirlerin alınması kararlaştırılmıştır. ${ }^{118}$ Meşrutiyetin ilk günlerinde Mitroviçe-Uzice demiryolu hattı hakkında rapor hazırlamakla görevlendirilen bir askerî komisyonun başkanlığını yürüten Muzaffer Paşa, "karşı-devrimci”" bir komploya destek olması için İsa Bolatinî ile haberleşmişse de durumdan haberdar olan İttihatçı zabitler, planları ele geçirip Muzaffer Paşa'yı yakalayarak Selanik'e göndermişlerdir. ${ }^{119}$

İsa en başından beri katılmadığı ve muhalif olduğu halde "Firzovik Besasını" ve karalarını bozmakla itham edilmiştir. İthamın bu şekilde dile getirilmesinin muhtemel nedenlerinden biri söz konusu toplantıya katılanların Arnavutlardan oluşmasıdır. Öte yandan İsa, halkı aşar ve orman rüsumunu vermemeleri yönünde teşvik etmiştir. Daha önce olduğu gibi bu kez de onun bölgeden uzaklaştırılması çarelerine bakılmıș ve münasip bir vesile ile Üsküp'e gönderilmesi söz konusu olmuştur. Ancak Kosova Valisi Üsküp’te bulunmasının uygun olmayacağını bundan dolayı da bir

111 “Albanian Chief Issa Bolitenatz A Picturesque Warrior”, Saturday Mail, June 21, 1913, p. 2.

112 Külçe, Firzovik..., s. 82.

113 Süleyman Külçe, Osmanlı Tarihinde Arnavutluk, Yeni Asır Matbaası, İzmir, 1944, s. 288. Süleyman Külçe, Balkan Harbi’nde

İhmal Faciaları, Yay. haz. Ercan Haytaoğlu, Çizgi Kitabevi Yay., Konya, 2018, s. 58-59. Külçe, Firzovik..., s. 22.

114 Külçe, Firzovik..., s. 85-89.

115 Andonyan, age., s. 158.

116 Külçe, Firzovik ..., 82.

117 Mustafa Ragib, age., s. 27.

118 BOA, TFR.I.KV, 228/22707, H. 24.08.1327 (10 Eylül 1909).

119 Aykut Kansu, 1908 Devrimi, çev. Ayda Erbal, İletişim Yay., 6. Bask1, İstanbul, 2011, s. 256-257. 
başka yere sevk edilinceye değin Selanik’te kalmasının daha münasip olacağını belirtmiştir. ${ }^{120}$

Mitroviçe'ye yaklaşık iki saat uzaklıktaki köyündeki kulesine çekilen İsa'nın İttihat ve Terakki aleyhindeki söylem ve ifadeleri Jön Türkleri hayli kızdırmıştır. Ancak İsa’nın bölgedeki nüfuzu bilindiği için onunla görüşerek fikri yapısını anlamak ve gerekirse vücudunu ortadan kaldırmak üzere Şemsi Paşa'nın oğlu Kolağası Ali Bey ile Süleyman Külçe kulesine gönderilmiştir. Yapılan görüşme esnasında İsa, İttihat ve Terakki ile Niyazi ve Enver Beyler hakkında ileri geri konuşarak onları aşağılamıştır. Mevcut halin geçici olduğunu tekrar eski günlere dönüleceğini düşünen İsa böylece İttihat ve Terakki’ye meydan okumuştur. ${ }^{121}$

İsa'nın kendisinden alınarak Hacı Ali Ağa'ya verilmiş olan çiftliği bazı devlet erkanından aldığı destekle tekrar ele geçirmiş olması, jandarmanın görevini yapmasına engel olması gibi nedenlerle birlikte yeni rejimin bölgedeki otoritesinin tesis edebilmesi için "şiddetle tedib ve tenkili elzem" hale gelmiştir. ${ }^{122}$ Bu kararın alınmasında İsa'nın hasmı olan Üsküp Mebusu Necip Draga'nın büyük bir etkisi olmuştur. İttihat ve Terakki Cemiyeti'nin Selanik’te bulunan Merkez-i Umumisinde nüfuz sahibi olan Draga, İsa'nın kendisini Mitroviçe'de bulunan fabrikasını ve Tirgoşte'deki ormanlarını yakmakla tehdit etmesi üzerine onu ortadan kaldırmak için her türlü yola başvurmaya başlamıştır. Necip Draga, İttihat ve Terakki Cemiyeti Mitroviçe şubesi üyeleri Miralay Fevzi (Çakmak), kaza kaymakamı Haydar, Doktor Mustafa, Hüseyin Ağa ve Hacı Eyüp'ü İsa Bolatinî meselesini görüşmek üzere İbrahim Deva'nın mağazasının üst katında toplamıştır. Fevzi Bey ve İbrahim Deva, üzerine asker gönderilmeksizin başka bir yolla ortadan kaldırılmasını eğer askerî bir harekât düzenlenir ve başarısızlıkla neticelenirse daha büyük gailelerin ortaya çıkacağını belirtmişlerdir. Ancak, Draga'nın nüfuzu nedeniyle onların uyarıları çok da göz önünde bulundurulmamış ve askerî bir harekâtla meselenin çözümü yoluna gidilmiştir. ${ }^{123}$

Mitroviçe Kaymakamı Haydar Bey tarafından bazı ön hazırlıklar yapılmaya başlanmış nasıl bir yöntem izlenmesi gerektiğine yönelik bir çalışma yapılmıştır. Kaymakama göre yanında on beş yirmiden fazla adamı bulunan İsa'nın yakalanması için büyük kuvvetlere ihtiyaç yoktu. Ancak İsa'nın sığındığı Bolatin köyünün mevkii, saklandığı kulenin sağlam yapısı ve sürekli tetikte bulunması girişilecek bir muhasaranın önündeki en büyük engeldi. Eğer ilk muhasarada elde edilemezse takibinin çok zor olacağının farkında olan kaymakam, ihtiyatlı davranılarak mevkie göre gerekirse muhasara hattının geniş ve sıkı tutulması görüşündeydi. Mitroviçe'de bulunan iki yüz acemi askerin yeterli olmayacağını da hesaba katan kaymakama göre getirilecek iki taburla kulesinde kuşatılan İsa ölü veya diri bir şekilde ele geçirilebilecekti. Haydar Bey, İsa Bolatinî’ye karşı güçlü bir kamuoyu oluşturmanın planını da yapmıştır. Kaymakama göre Priştine, İpek ve Prizren'de yayımlanacak bir genelge ile İsa'nın hükümetin emirlerine uymadığı, vatanperver Arnavutların yardımlarıyla tekrar ilan edilen Kanun-i Esasi aleyhinde faaliyet göstererek Firzovik İttifakını bozduğu ilan edilirse İsa Bolatinî’ye karşı yapılacak askerî harekât bölge halkı tarafından olumlu karş1lanacaktı. ${ }^{124}$

Yapılan hazırlıklardan sonra Selanik'ten gönderilen bir kurmay subay ile bir tabur asker bir sabah ansızın İsa'nın kulesini sararak askerî harekâtı başlatmışlardır. Fırsat ve imkânı olmasına rağmen çarpışmadan kaçmayı şanına yakıştıramayan İsa, kendisini kuşatan birliğe karşı koymuştur.

120 BOA, TFR.I.KV, 228/22707, H. 24.08.1327 (10 Eylül 1909).

121 Külçe, Osmanlı..., s. 359-360

122 BOA, TFR.I.KV, 228/22707, H. 24.08.1327 (10 Eylül 1909).

123 Külçe, Osmanlı..., s. 360-361.

124 BOA, TFR.I.KV, 211/21005, H. 24.09.1326 (20 Ekim 1908). 
Soğuk ve karlı bir mevsimde üç gün süren çatışma sonunda yaralanan İsa, İpek tarafına kaçmak zorunda kalmıştır. Külçe, İsa'nın yaralanmasını şu şekilde değerlendirmiştir: "Bu kan, Meşrutiyetin döktüğü ilk Arnavut kanı idi. Bu kan, gün geçtikçe büyüye büyüye yalnız Arnavutluk'u değil, bütün Rumeli'yi boğan şuursuz, hırçın bir deniz gibi köpürdü. Durdu. Her iki tarafta ifrata düşmüştü.."125

Binbaşı Mehmet Nuri (Conker), Zâbit ve Kumandan isimli kitabında kendisinin de yer aldığı askerî harekatta yaşananları şu şekilde ifade etmiştir:

“Kasim 1908'de ünlü asilerden İsa Bolatin, Meşrutiyet Hükûmetine ilk isyan ettiğinde üzerine bir taburla, iki top yollanmıştı. Sabah karanliğında Mitroviçe'den yola çıkan kolun sonu, sisli ve karlı bir gün doğarken bir buçuk saat mesafedeki Bolatin köyüne hâkim bir tepenin yamacinda Bolatinliçetesince pusuya düşürülmüştü. Illeridekibölü̈ler hemen tepelere saldırıya geçmişlerdi fakat alacakaranlıktan ve tipiden yararlanan Arnavutlar, kolun büyük kismin tesir altında tutuyorlardı. Tabii bu sirada hepimiz düz yolda kar içinde yattyor, önümüzdeki düşmanın mevziisini tespite çalışlyorduk. Birkaç piyade askerin kanı, karları ala boyamış, birkaç top katırı da devrilmişti. Askerdeki şaşkınlık görüntüsü çok üzücüydü. Yanımda, Topçu Komutanı Üsteğmen Manasttrlı Faik vardl. (Şu anda 3'üncü Top̧̧u Alay 7'nci Bölük Komutanı ve Yüzbaşı) Ondan, askerimizin moralini düzeltmek, Arnavutlarınkini de bozmak üzere yüksek nişangâhta ateşe başlamasın istedim. Hemen ayağa kalktı. Askerlerini de kaldırdı veyol kenarındaki hendeğe düşen topu düzlüğe çıkardılar. Atı̧̧ hazırlanırlarken askerlerden biri vurulup şehit düştü. Diğer askerler topu bırakip gizlendiler. Üsteğmen Faik, subaylı̆̆a hiç halel getirmedi ve askerlere öyle şeyler söyledi ki hemen tekrar topa sarlldllar. Bu sefer de top çavuşu gözünden vurulup düştü. Ben, artık bunların yapacağl işten vazgeçmek üzereydim. Tek topçu subayı olarak fazlasıyla ihtiyacımız olan subayı da kaybetmekten korkuyordum. Üsteğmen Faik' in mertliği işi halletti. Askerlerine örnek subay tavriyla, toplan ateşe başladı. Az sonra da ilerideki bölükler düşmanla kavraşmışlar ve pusudan kurtulmak mümkün olmuştur. ${ }^{126}$

Yaralı haldeki İsa, yirmi beş adamıyla birlikte 28 Kasım'da İpek'in İstenik köyüne sığınmıştır. ${ }^{127}$ Çoğu kâgir, muhkem ve sağlam kulelerden oluşan yüzden fazla hanenin bulunduğu köy, sarp mevkii nedeniyle de oldukça korunaklıydı. Hasan Süleyman Şaban'ın evinde Tahir Solot tarafindan tedavi edilen İsa, adamlarını gönderdiği civar köylerden taraftar toplamaya çalışmıştır. Yakalanması için yeni bir girişimde bulunulmadığını gören cahil halk, ona büyük bir önem atfederek etrafında toplanmaya başlamışlardır. Yavaş yavaş artan taraftar sayısı onun özgüvenini ve ümidini artırmıştır. İsa'nın bu durumundan en fazla tedirginlik duyan İpek Mutasarrıfı İsmail Hakkı Bey olmuştur. Mutasarrıf, İsa'nın kışla ve hükümet konağını işgal ederek kışlada bulunan iki cebel topunu ele geçirmesinden ortaya çıkan manzaranın başta Avusturya olmak üzere Avrupa basınına büyük bir firsat vermesinden endişe ediyordu. Mutasarrıfın bir başka vehmi, çıkan olaylar esnasında telgrafhaneyi ele geçirmeleri durumunda hükümetle olan tüm iletişimin kesileceği ve işlerin daha da kötüye gideceği şeklindeydi. Bu yüzden İstenik'te bulunan İsa'nın takibine devam edilmesini veya İpek’e kuvvetli bir askerî birliğin gönderilmesini istemiştir. ${ }^{128}$

125 Külçe, Osmanlı..., s. 361.

126 Birinci Fırka Erkân-1 Harbi Mehmet Nuri (Conker), Zâbit ve Kumandan, (Zabit ve Kumandan ile Hasb-ı Hâl'in içerisinde),

Yay. haz. Ahmet Tetik, vd., Genelkurmay ATASE Yay., Ankara, 2010, s. 102-103.

127 BOA, TFR.I.KV, 228/22707, H. 24.08.1327 (10 Eylül 1909).

128 BOA, TFR.I.KV, 228/22707, H. 24.08.1327 (10 Eylül 1909). 
İsmail Hakk1 Bey, İpek'in ve belki de her şeyden önce kendi güvenliğini temin edebilmek için yeni bir tedbire başvurmuştur. İsa'nın "dağdağasızca" yakalanması ve "itlafı" için ismini tespit edemediğimiz bir kişi ile yüz elli lira karşıllı̆ında bir mukavele yapmıştır. İsa'yı birkaç hafta içerisinde "itlaf" edeceğini taahhüt eden kişiye depozito verilmesi için söz konusu meblağın kısa süre içerisinde gönderilmesini Rumeli Müfettişliğine gönderdiği 16 Ocak 1909 tarihli bir yazıyla istemiştir. Teklifi olumlu karşılayan Müfettiş Vekili Mahmud Şevket Paşa, Heyet-i Teftişiyye tahsisatından karşılanmasına karar verilen paranın biran evvel İpek'e gönderilmesini sağlamıştır. Bir iki hafta içerisinde başarılı bir sonuç alınması beklenen bu girişim, netice vermemiş ve İsa meselesi büyüyerek devam etmiştir. ${ }^{129}$

İsa'nın hareket kabiliyetini sınırlamak isteyen Kosova Valiliği, II. Abdülhamid'in ihsan ettiği değirmen taşı madeni imtiyazını elinden almaya teşebbüs etmiştir. Valilik madeninin Mitroviçe Belediyesine veya Orman İdaresine teslim edilebileceği fikrindeydi. Ancak konuyu hukuki olarak değerlendiren Dahiliye Nezareti, bir mahkeme kararı olmaksızın elinden alınamayacağını ifade ederek bu fikre sicak bakmamıştır. ${ }^{130}$

Meşrutiyet idaresi aleyhinde etrafına topladığı adam sayısını her geçen artıran İsa'nın bahar mevsimin gelmesiyle birlikte başlarına daha büyük gaileler açacağını gören Dahiliye Nezareti, İsa ve adamlarının dağa çıkmadan önce sevk edilecek askerî kuvvetler ile etkisiz hale getirilmesi düşüncesindeydi. Nezaret, İsa meselesini kati bir surette neticelendirmek yönündeki kararlığıyla bu düşüncesini 23 Ocak 1909'da Rumeli Müfettişliğine ve Kosova Valiliğine bildirmiştir. ${ }^{131} \mathrm{Bu}$ çerçevede Kosova Valisi Mahmud Hadi, gerekli kuvvetin sevki için 3. Ordu ve Mitroviçe Furkası Kumandanlığı ile İpek Mutasarrıflığından gerekli hazırlıkların yapılmasını istemiştir. Konuyu sıkı bir şekilde takip eden Dahiliye Nezareti, bununla da yetinmeyerek hazırlıkların aksamaksızın sürdürülmesi için Harbiye Nezaretinden de icap edenlere gerekli tebligatın yapılmasını istemiştir. ${ }^{132}$

1909 yılının Ocak ayından beri İsa'nın yakalanması için yapılan hazırlıklardan ve girişimlerden bir netice alınmadığını gören Sadaret, 27 Şubatta Rumeli Müfettişliğine silah tedarik ettiği öğrenilen İsa'nın bahardan önce yakalanmasını ve faaliyetlerinin sona erdirilmesini tavsiye etmek zorunda kalmıştır. ${ }^{133}$ İpek'te bulunan birliğin kifayetsizliği, İsa'nın sığındığı İstenik köyünün “cesim dağlık ve pek metin" bir yapıya sahip oluşu bununla birlikte İsa'ya çevre köylerden gelen taraftarlarıyla birlikte yaklaşık iki bin adamın yardım edeceği tahmini askerî harekâtın ertelenmesine neden oluyordu. ${ }^{134}$ Tüm bu nedenler ve ihtimaller göz önünde bulundurulduğunda İsa'ya kesin bir darbe vurabilmek için kalabalık ve kuvvetli bir askerî birlik hazırlanması gerekliliği ortaya çıkmıştır. Hükümetin artan baskıları üzerine Rumeli Müfettiş Vekili Mahmud Şevket Paşa, bir yandan İpek Mutasarrıflığıyla bir yandan da Üçüncü Ordu Kumandanlığıyla irtibata geçerek başında Mirliva Cavit Paşa'nın bulunduğu üç tabur ile bir seri ateşli bataryanın İpek'e sevkini sağlamıştır. İpek'te bulunan taburun da Cavit Paşa komutasındaki birliğe dâhil edilmesiyle oluşan dört taburluk askerî birlik vasitasıyla İsa meselesinin kapatılması bekleniyordu. ${ }^{135} \mathrm{Bu}$ arada 22 Mart'ta Babiali tarafindan Rumeli Müfettişliğine İsa'nın düzenlenecek askerî harekâtla yakalanamaması ihtimalinin çok yüksek olduğu bundan dolayı da yakalanması ve faaliyetlerine son verilmesi için itimat edeceği

129 BOA, DH.MKT, 2715/30, H. 29.12.1326 (22 Ocak 1909).

130 BOA, DH.MKT, 2740/5, H. 25.01.1327 (16 Şubat 1909).

131 BOA, DH.MKT, 2715/30, H. 29.12.1326 (22 Ocak 1909). BOA, DH.ŞFR, 409/47, R. 11.11 .1324 (24 Ocak 1909).

132 BOA, DH.MKT, 2718/52, H. 02.01 .1327 (24 Ocak 1909).

133 BOA, BEO, 3499/262395, H. 06.02.1327 (27 Şubat 1909).

134 BOA, TFR.I.KV, 228/22707, H. 24.08 .1327 (10 Eylül 1909).

135 BOA, BEO, 3499/262395, H. 06.02.1327 (27 Şubat 1909). 
bir kişinin gayri resmî olarak İpek'e gönderilmesi ve İsa'yı ikna ederek önce İstanbul'a daha sonra da Anadolu'da bir yere gönderilmesinin düşünüldüğü bildirilmiştir. ${ }^{136} \mathrm{Bu}$ noktada Babıali tarafından görüşü sorulan Müfettişlik, tüm hazırlıkların İsa'nın yakalanması için yapıldığının herkesçe bilindiğini hatta bunun gazetelerde dahi yazılmış olduğu halde harekâttan vazgeçilmesinin farklı şekillerde anlamlandırılacağını belirterek bu teklife karşı çıkmıştır. Mahmud Şevket Paşa, harekâtın ertelenmesinin asker ve bölge üzerinde oluşturacağ 1 olumsuz etkiyle birlikte ileride bölgede yapılması planlanan 1slahata da zarar verebileceğini düşünüyordu. Ona göre hükümet ve şan-1 askeriyyeyi muhafaza için harekâtın yapılması bir zaruretti. ${ }^{137}$

23 Mart'ta Rumeli Müfettişliği, İpek Mutasarrıflığı ve Kumandanlığından, İstenik köyünün kuşatılarak İsa'ya silahını bırakarak teslim olması çağrısında bulunulmasını eğer bunu kabul ederse hakkında herhangi bir muamele yapılmaksızın İpek'e getirilmesini yok eğer kabul etmeyerek askere karşı mukavemet ederse alınan askerî tedbirlere bağlı olarak ölü veya diri ele geçirilmesini istemiştir. ${ }^{138}$ İsa'yı yakalamak için İpek'e giden 18. Nizamiye Fırkası Kumandanı Mirliva Cavit Paşa'nın emrinde beş nizamiye taburu, bir süvari bölüğü, bir seri ateşli ve iki süvari bataryasıyla dört cebel topu bulunuyordu. Tüm hazırlıklar yapıldıktan sonra, 24 Mart 1909'da İpek’te bırakılan bir taburun dışındaki tüm askerî birlikler Cavit Paşa ve İpek Mutasarrıfı İsmail Hakkı Bey'in komutasında hareket ederek İstenik ile İstraliçe-i Zîr ve İstraliçe-i Bala köylerini kuşatmışlardır. İstenik'e gönderilen bir jandarmayla köyün ileri gelenleri çağrılarak onlardan İsa'yı teslim etmeleri istenmiş̧ir. ${ }^{139}$ Ancak İsa, harekât başlamadan önceki akşam köyü terk ederek bir kez daha kaçmıştır. Her ne kadar İsa kaçmış olsa da ona yardım ve yataklık ettiklerini itiraf edenler tutuklanmış, evleri tahrip edilmiş ve yakılmışıtır. Bununla birlikte köyde hiç vakit kaybetmeksizin nüfus sayımı yapıldığı gibi o güne değin hiç yapılmayan "ağnam tadadına" başlanmıştır. Yapılan aramalar esnasında da bazı silahlara el konulmuştur. ${ }^{140}$

Yaklaşık olarak dört ay boyunca kaldığı İstenik köyü alınan askerî tedbirlerle muhasara edilmiş olmasına rağmen İsa, bir kez daha kaçmayı başarmıştır. Yapılan tahkikatla yaralı bir şekilde İstenik'e gelen İsa'yı tedavi ederek uzun süre onu misafir edenin Tahir Solot olduğu öğrenilmiştir. İstenik muhasara edilmeden önce kaçan Tahir'in evi de yıkılanlar arasındadır ancak oldukça sağlam bir yapıya sahip olan evin tahrip edilebilmesi için çok sayıda top atı̧ı yapılmak zorunda kalınmıştır. Yaşanılan bu durum bölgede oldukça yaygın bir şekilde bulunan kule tabir edilen muhkem yapıları gündeme getirmiştir. Kalın ve yüksek duvarlarıyla küçük mazgallar şeklindeki

136 BOA, BEO, 3629/272142, H. 29.02.1327 (22 Mart 1909).

137 BOA, TFR.I.KV, 228/22707, H. 24.08.1327 (10 Eylül 1909).

138 BOA, TFR.I.KV, 228/22707, H. 24.08.1327 (10 Eylül 1909).

139 BOA, BEO, 3517/263747, H. 29.02 .1327 (22 Mart 1909). 19 Temmuz 1909'da Tasvir-i Efkâr'da röportaj1 yayımlanan Cavit Paşa, muhasara esnasında eşkıyanın camiye sığındığından hatta minareden attıkları kurşunlarla bir topçu neferini şehit ettiklerinden bunun üzerine minareye top atışı yapmak zorunda kaldıklarından bunun neticesinde de minarenin yıkıldığından bahsetmiştir. "Arnavutluk Ahvali Hakkında Cavit Paşa ile Mülâkât", Yeni Tasvir-i Efkâr, Nu: 50, 19 Temmuz 1909, s. 2. Mecliste Cavit Paşa'nın uygulamalarına yönelik eleştiriler için bk. Mucize Ünlü, Kosova Vilayeti, Gece Kitaplı̆̆ı, Ankara, 2014, s. 294-296.

140 İpek Mutasarrıfı İsmail Hakkı Bey, askerî harekât başlamadan önce Abdülhamid döneminde şımartıldıkları kanaatinde olduğu İpek ve Yakova ahalisinin bu haline son verilmesi için İsa Bolatinî meselesinin iyi bir vesile olacağı görüşündedir. Bölgede ilan edilecek bir idare-i örfiye ile geniş çaplı bir ıslahata girişilmesi böylece nüfus ve emlak tahriri yapılarak asker alma işlemlerinin yapılabileceğini düşünmektedir. Ancak hükümet, sevk edilen kuvvetin söz konusu 1slahatı herhangi bir zorlukla karşılaşmaksızın tamamlamasının oldukça güç olduğunu eğer bir başarısızlıkla karşılaşılırsa takviyesinin de zor olacağını belirterek İsa'nın tenkilinden sonra konunun tekrar konuşulmasını ifade ederek öneriyi reddetmiştir. BOA, BEO, 3517/263747, H. 29.02 .1327 (22 Mart 1909). 
pencereleri yapıya içerisindeki insanları dışarıdan gelebilecek saldırılara karşı muhafaza edebilecek bir nitelik kazandırıyordu. İpek Mutasarrıfı İsmail Bey’e göre “aile iskanına mahsus olmayan ve cümlesi bir müstahkem ordugâh halinde bulunan ve sırf hükümete mukavemet için birer eşkıya tahassungahı olarak inşa edilmiş olan kulelerin" yıkılması hükümetin bölgedeki hakimiyetinin tesisi için elzemdi. ${ }^{141}$

Nereye kaçtı̆̆ı çok da bilinmeyen İsa'nın Yakova Malisyasına gitmiş olması ve oradan adam toplayarak İstenik üzerine saldırması bekleniyordu. Bundan dolayı da İpek Mutasarrıflığından bölgenin kontrol altında tutularak herhangi bir saldırıya karşı dikkatli olunması ve eğer gerek görülürse askerî yardım için Üçüncü Ordu Kumandanlığı ile irtibat halinde olunması istenmiştir. ${ }^{142}$ Bu arada 6 Nisan'da İsa’nın Gusine kazasıyla İşkodra vilayetinin ve Yakova kazasının kesiştiği bölge civarında oldukça sarp bir noktadaki Dargoneli köyünde Ali Geçan adında birinin evinde bulunduğuna dair istihbarat alınmıştır. İpek Mutasarrıfı İsmail Hakkı Bey, o günlerde Gusine üzerine yapılacak olan askerî harekatın Dargoneli'ye de yöneltilmesi ve oradan Yakova Malisyasına doğru uzatılmasını teklif etmiştir. Ancak, İpek, Tirgovişte ve Gusine 1slahatı tamamlanmaksızın Yakova Malisyasına gidilmesi uygun görülmemiştir. ${ }^{143}$

Asker sayısının azlığı ve sarp arazi yapısı İsa Bolatinî ve avenesinin takibini oldukça güçleştirmiştir. Gusine bölgesinde Plavalı Fardik Haso ve kardeşleriyle yakınlık kuran İsa, kaza eşrafı ile Belediye Başkanı ve azasının iddiasına göre onlarla birlikte Osmanlı Devleti ile Karadağ arasında siyasî bir mesele çıkarmak için çalışıyorlardı. ${ }^{144} \mathrm{Bu}$ sırada patlak veren 31 Mart Vakası sonras1 27 Nisan 1909'da II. Abdülhamid tahttan indirilerek Selanik'e sürgüne gönderilmiştir. İsa Bolatinî, Abdülhamid'in tahttan indirilmesinden rahatsız olmuştur. Bu rahatsızlı̆̆ının arkasındaki sebep, Padişahın birçok ihsan ve lütfuna mazhar olmasından kaynaklanmaktaydı. 1902 yılında İstanbul'a gelerek burada "bey" unvanıyla sultanın “Arnavut muhafizlarının” başına getirilmesi ve yaklaşık dört yıl boyunca bu vazifeyi sürdürmüş olması, Bolatin'deki değirmentaşı ocağının işletme hakkının verilmesi II. Abdülhamid'in onun için ne kadar büyük bir velinimet olduğunun göstergesidir. Sultan tahttan indirilirken İsa Bolatinî de Kosova’nın birçok yerinde Jön Türklerin koyduğu vergilere karşı çok şiddetli ayaklanmalar başlatmıştır. ${ }^{145}$ İngiliz basınında Osmanlı askerî çevrelerince isyanın İsa Bolatinî’ye dayandırıldığ 1 ve bir türlü yakalanamadığına yönelik haberlerin yanı sıra isyanın millî bir karaktere büründüğü şeklinde değerlendirmeler de yapılmıştır. Oysa ki aynı haberlerde Arnavutların yeniliklere karşı olduklarını deklare ettikleri, şeriatın veya yerel kuralların tesis edilmesini istedikleri bilgisine de yer veriliyordu. ${ }^{146}$

İsyan karşısında Cavit Paşa, başında bulunduğu küçük ordusuyla İpek ve Yakova taraflarını dolaşarak halkın çok da benimsemeyeceği tedbirler almıştır. İki yıllık vergi toplamış, silahlara el koymuş, asker alımı yapmış ve altmış kadar kuleyi yıktırmıştır. Eylül ayında Luma bölgesinde başlayan bir isyana karşı tekrar Mitroviçe'den hareket eden Cavit Paşa, çok sert bir direnişle karşılaşmış ve Batı Kosova' dan tümüyle çekilmek zorunda kalmıştır. ${ }^{147}$

1910 yılı baharında vergi yüzünden Kosova'nın kuzey ve kuzeydoğu taraflarında yeni bir

141 BOA, DH.MKT, 2715/30, H. 29.12.1326 (22 Ocak 1909).

142 BOA, TFR.I.KV, 228/22707, H. 24.08.1327 (10 Eylül 1909).

143 BOA, TFR.I.KV, 228/22707, H. 24.08.1327 (10 Eylül 1909).

144 BOA, DH.MKT, 2792/91, H. 20.03.1327 (11 Nisan 1909). BOA, DH.MKT, 2801/51, H. 13.04.1327 (4 May1s 1909).

145 Malcolm, age., s. 297.

146 “Albanian Revolt”, Dublin Daily Express, August 31, 1909, p. 8.

147 Malcolm, age., s. 298. 
isyan patlak vermiştir. Kısa süre içerisinde yayılan isyan, Arnavut klan reislerinin 1881'den beri ilk kez büyük ölçekli ve eşgüdümlü olarak planladıkları bir harekete dönüşmüştür. İsa Bolatinî de İdris Seferi ile birlikte hareket etmiştir. İsyan karşısında hükümet, 16 bin kişilik bir orduyu Üsküp'e göndermiştir. İsyancılar, ilk etapta İdris Seferi komutasında 9 bin adamı demiryolunu kapatmak için Kaçanik’e göndermişler ancak ağır kayıplar vererek geri çekilmek zorunda kalmışlardır. Bir sonraki çatışma Firzovik’ten Prizren'e giden yol üzerindeki Çernalova (Carraleva)'da meydana gelmiştir. İsa Bolatinî ve İdris Seferi Osmanlı birliklerinin batı yönünde ilerlemesini engellemeye çalışmışlar ama Osmanlı birliklerinin etraflarından dolaşarak önlerini kesmesi üzerine geri çekilmek zorunda kalmışlardır. Osmanlı kuvvetlerinin Mayıs ortalarında Prizren'i, Haziran sonunda Yakova ve İpek'i tekrar kontrol altına almalarıyla isyan kesin bir biçimde bastırılmıştır. ${ }^{148}$

1910 yılının Haziran ayının ilk günlerinde İsa Bolatinî, üç oğlu ve üç yeğenin de aralarında bulunduğu on üç kişiyle birlikte Karadağ' $1 n$ Velika kasabasına geçerek Karadağ'a sığınmıştır. Daha sonra Andraviçe'ye geçen İsa, görevlendirilen bir memurun refakatinde Çetine'ye gönderilmiştir. ${ }^{149}$ Osmanlı hükümeti iadesi için Çetine Sefareti aracılığıyla teşebbüste bulunmuşsa da bundan bir netice alması mümkün olmamıştır. Mukabele-i bilmisil ile hareket eden Karadağlılar, Karadağ Prensi aleyhine faaliyette bulunarak Osmanlı'ya iltica edenler nasıl iade edilmeyerek huduttan uzak yerlere gönderilmişse onlar da İsa ve avenesini iade etmeyerek sınırdan uzak yerlere göndermişlerdir. ${ }^{150}$ Mukabelede bulunduklarını açık bir şekilde ifade etmekten çekinmeyen Karadağlılar, İsa’yı sınır dışı edeceklerini söyleyerek Osmanlı hükümetini ümitlendirmişlerse de bunu yapmadıkları gibi muhafazası için jandarma görevlendirmişlerdir. ${ }^{151}$ İsa Bolatinî, Karadağ'a firar eden diğer Arnavut rüesasıyla birlikte affedilmeyi bekleseler de genel kanaat uzun y1llar boyunca halka zulmeden "eşirra güruhundan” bu insanların affedilmelerinin uygun olmayacağı yönündeydi. ${ }^{152}$

Bu arada 1910 yılının Kasım ayında hükümete Nikşik’te bulunan İsa ve diğer Arnavut firarilerin Çetine'ye nakledildiği haberiyle İsa'nın Karadağ hükümeti tarafından emrine yeterli sayıda askerî kuvvet verilmesi durumunda Mitroviçe'ye kadar giderek birtakım cinayetler işleme emelinde olduğuna yönelik bilgiler gelmiştir. Hariciye Nezareti aracılığıyla Çetine Sefareti tarafından bir tahkikat yapılarak bu bilginin gerçek olup olmadığının araştırılması istenmişse de bir sonuç alınamamıştır. ${ }^{153} \mathrm{Bu}$ haberler çok da asılsız değildi. Karadağ'a firar eden Arnavutlar ve Katolik Malisörler 1911 yılı ilkbaharında Arnavutluk'ta yeni bir isyan başlatmaya karar vermişlerdir. İşkodra ve Kosova vilayetlerinde başlatılacak isyanın daha sonra Manastır ve Yanya’ya yayılması planlanmıştır. Amaçları İstanbul hükümetini Arnavutluk'a özerklik vermesi konusunda sıkıştırmaktı. Karadağ, isyanın sadece ilhak etmek istediği bölgelerle sınırlı kalmasını istiyordu. 1911 Martının ilk günlerinde Karadağ'da toplanan Malisörler Kongresinde Prens Nikola, Kuzey Arnavutluk'a yönelik toprak emellerini açıkça ortaya koymuş, isyanın başarıya ulaşmasından sonra o bölgelerde Karadağ bayrağının dalgalanacağını ifade etmiştir. Bu doğrultuda Kosova'da isyan ateşini yakması için İsa Bolatinî’ye emir vermiştir. İsa Bolatinî’ye destek ve yardım amacıyla

148 Malcolm, age., s. 299.

149 BOA, Dahiliye Nezareti Muhaberat-ı Umumiye İdaresi Evrakı (DH.MUI), 80/38, H. 19.07.1328 (27 Temmuz 1910).

150 BOA, HR.SYS, 133/19, M. 16.06.1910. 18 Temmuz 1910'da Çetine Sefareti tarafindan Karadağ'a firar eden Arnavutların isimlerini içeren 26 kişilik bir liste hazırlanmıştır. Bu listede İsa ve doğrudan doğruya onunla bağlantılı 14 kişinin adına yer verilmiştir. Buna göre İsa'nın yanında Halil, Mustafa ve Adem isimli üç oğlu ile Tafil, Yunus ve Yaşar isimlerindeki üç yeğeni bulunuyordu. Bunların dışında iki kayınbiraderi, bir ahiret kardeşi ve dört akrabası da listede bulunuyordu. BOA, HR.SYS, 133/23, M. 18.07.1910.

151 BOA, HR.SYS, 133/28, M. 22.08.1910.

152 BOA, HR.SYS, 133/30, M. 22.09.1910. BOA, HR.SYS, 133/34, M. 10.10.1910. BOA, HR.SYS, 133/44, M. 16.11.1910.

153 BOA, HR.SYS, 133/43, M. 10.11.1910. 
Prizen'e kadar yol açık tutulacak; Karadağ ordusu hazır bekletilecekti. Ortaya çıkan manzara ile Karadağ'ın Arnavutluk üzerindeki niyetlerini gören bazı isyancı lider buna tepki göstermişlerdir. ${ }^{154}$

Öte yandan 1911 yılının Mart ayında Avusturya hükümeti tarafından Osmanlı Hariciyesine Taşlıca'ya giden İsa Bolatinî ve beraberindekilerin Osmanlı topraklarına girebilmek için sahte pasaport tedarikine çalıştıkları haber verilmiştir. ${ }^{155}$ Tüm bu iddia ve haberlere rağmen 1911 yılının Nisan ayında Osmanlı Devleti'nin Çetine'de bulunan sefaretine giden İsa ve yanındakiler, son nefeslerini memleketlerinde vermek istediklerini bundan dolayı da haklarında bir af çıkarılmasını istemişlerdir. Daha fazla Karadağ' da yaşayamayacaklarını ifade eden firariler, başka bir yere de gitmek istemediklerini belirterek memleketlerine gidip bir ormana çekilerek orada haklarında verilecek son kararı bekleyeceklerini söylemişlerdir. ${ }^{156}$ Sefir Sadreddin Bey, firarilerle yaptığ görüşmede daha önce hükümetten aldığı emre bağlı olarak cezalarının hafifletildiğini belirttikten sonra silahlarını bırakarak devlete ve Padişaha bağlılık ve sadakatlerini beyan etmeleri durumunda affedilebileceklerini söylemiştir. Sefirin firarilerin ülkeye dönüşlerini sağlamak, dönüşlerinde Malisörler tarafindan başlatılan ayaklanmaya katılmalarını engellemek ve Karadağ'ın elinde Osmanlı aleyhine bir silah olmalarının önüne geçmek için söylediği sözler bir af vaadi olarak nitelendirilmiştir. ${ }^{157}$ Hatta İsa'nın sefarete gelerek "arz-1 dehalet" etmiş olmasına rağmen, hakkında afv-1 şahane çıkarılmadığı için etrafına toplanan bir takım "haşerat" ile tekrar bir gaile çıkaracağı yönünde söylentiler çımıştır. ${ }^{158}$

İttihatçıların nüfuzlarını artırmak, halkın hükümete ve Padişaha bağlılığını teşvik etmek ve Arnavutları itaat altına almak için düzenledikleri Sultan Reşad'ın Kosova seyahati ${ }^{159}$ esnasında 1910 Arnavut isyanına katılan Süleyman Batuşa ve Taşlıcalı Hasan Ağa Osmanlı tahtına sadakat yemini etmeleri üzerine bağışlanmışlardır. Ancak İsa Bolatinî, beklenenin aksine sadakat yemini için Üsküp'e gitmemiştir. ${ }^{160}$ Padişahın Meşhed-i Hüdavendigar'a ve Kosova Ovasına ziyarete geldiğinde kendisini de davet ettiğini ifade eden İsa, yanında Sadrazam Hakkı Paşa ve Mahmud Şevket Paşa'nın bulunduğunu öğrenince onları görmemek için bu daveti reddettiğini ifade etmiş̧tir. ${ }^{161}$ En nihayetinde Sultan Reşad'in seyahati ile beklediği affa ulaşan İsa Bolatinî, tekrar Mitroviçe'ye dönmüştür. Karadağ'da kaldığı dönemde Prens Nikola tarafından birkaç defa yemeğe davet edilerek Prenses Milena'nın yanına oturtulan İsa, o günlerde gördüğü ilgiden oldukça memnun kalmıştır. 1913 yılında Londra'da verdiği bir mülakatta yöneltilen "Kral Nicholas hakkında ne düşünüyorsunuz?" şeklindeki soruya "O ve halkı için sadece iyi şeyler söyleyebilirim." cevabını

154 Hasan Bello, Osmanlı ve Arnavut Kaynaklarına Göre Arnavutluk'ta 1911 Malisörler Ísyanı, Mimar Sinan Güzel Sanatlar Üniversitesi Sosyal Bilimler Enstitüsü, Yayımlanmamış Yüksek Lisans Tezi, İstanbul, 2009, s. 38.

155 BOA, HR.SYS, 134/29, M. 23.03.1911.

156 BOA, HR.SYS, 134/34, M. 05.04.1911.

157 BOA, HR.SYS, 134/40, M. 13.05.1911. Firarilerin idam cezalarının hafifletildiği, ülkeye döndüklerinde kötü bir muameleyle karşılaşmayacakları, hakkında takibat olmayanların serbest bir şekilde memleketlerine dönebileceklerine dair Meclis-i Vükela tarafından alınan karar için bkz. BOA, BEO, 3875/290604, H. 02.04 .1329 (2 Nisan 1911).

158 BOA, HR.SYS, 134/40, M. 13.05.1911.

159 Mevlüt Çelebi, “Rumeli’ye Veda Ederken Sultan Reşad'ın Kosova’yı Ziyareti”, Yeni Türkiye, S. 68 (Mart-Haziran 2015), Balkanlar Özel Sayısı III, s. 3291.

160 Erik J. Zürcher, Osmanlı Imparatorluğu’ndan Atatürk Türkiye’sine Bir Ulusun İnşası Jön Türk Mirası, çev. Lütfi Yalçın, Akılçelen Kitaplar Yay., 1. Baskı, Ankara, 2015, s. 140. Halid Ziya Uşaklıgil, Saray ve Ötesi, Yay. haz. Nur Özmel Akın, Özgür Yay., İstanbul, 2003, s. 497. Lütfi Simavi, Son Osmanlı Sarayında Gördüklerim, Yay. haz. Sami Kara, Nurer Uğurlu, Örgün

Yay., 2. Bask1, İstanbul, 2004, s. 149.

161 “Albanian Chief”, Saturday Mail, June 21, 1913, p. 2. 
vermiştir. ${ }^{162}$

1911 yılının Temmuz ayında Hariciye Nezareti yazışmalarında General Yanko'nun İsa’yı çağırdığı ve İpek'te isyana teşvik ve davet ettiği ancak İsa'nın bunu kabul etmediği bilgisine yer verilmiştir. ${ }^{163}$ Aynı yılın Aralık ayında da İsa ve Süleyman Batuşa'nın Karadağ'a davet edilerek kullanılmak istenildiği, buna firsat verilmeyerek esasen devletin bunları kullanması gerekliliği üzerinde durulmuştur. ${ }^{164}$

Firarda olduğu dönemde tasarrufunda bulunan taş ocaklarının hasılatı olan 40.282 kuruşun mahkeme kaydı olmaksızın maliyeye gelir olarak kaydedilmişti. Bölgede sahip olduğu nüfuz ve itibar göz önünde bulundurularak Meşrutiyet hükümetine "1sınmasını temin" etmek ve bağl1lığını sağlamak için söz konusu paranın kendisine ödenmesine karar verilmiştir. ${ }^{165}$ Hükümet, firarda olduğu dönemde alamadığı hasılatı ödeyerek gönlünü kazanmaya çalışsa da İsa, eski alışkanlıklarından vazgeçmemiş ve çok kısa bir müddet sonra hükümet aleyhinde faaliyetlerine tekrar başlamıştır. İsa Bolatinî, 16 Mayıs 1912'de Mitroviçe ve Vulçitrin bölgesindeki camilere bir mektup göndermiştir. Cuma namazı için camilerde toplanan cemaate okuttuğu mektubunda vatanını seven insanları silahlı veya silahsız köyü Bolatin'in etrafındaki köylerde hazırlatmış olduğu konaklara davet etmiştir. Çağrısına uymadıkları takdirde felaketlerinin muhakkak olduğunu belirterek asker ve jandarmaya karşı savaşmalarını istemiştir. ${ }^{166}$ Halka silah dağıtarak isyana teşvik eden İsa, yukarıda belirttiğimiz üzere, tehditle idaresine aldığı asilerle Mitroviçe civarında "sarp kayalıklar arasında kartal yuvasını" andıran kulelere çıkarak mevzilenmiştir. ${ }^{167}$ Tüm amacı jandarmaları Mitroviçe'den çıkarmak olan İsa'ya ${ }^{168}$ karşı askerî ve mülkî tedbirler alınması kararlaştırılmış olmasına rağmen o, köyüne gelen halka serbest bir şekilde silah dağıtarak yeni bir ayaklanma için hazırlıklarını sürdürmüştür. ${ }^{169}$

20 Mayıs'ta bir araya gelen Bayram Curri, Rıza Bey, İsa Bolatinî, Hasan Priştine ve Necip Draga gibi Arnavut liderler, hükümetin düşürülmesi için bir ayaklanma tertibi konusunda fikir birlikteliğine ulaşmışlardır. Hükümetten eğitim, idare, dil ve ekonomik alanlarda birtakım taleplerde bulunmuşlardır. ${ }^{170}$ Haziran ayı sonlarında Hasan Priştine, İsa Bolatinî, Rıza Bey ve Bayram Curri tarafından imzalanan manifesto ile de halifeliğe ve Osmanlı anayurduna bağlı olduklarını Jön

162 “Albanian Chief”, Saturday Mail, June 21, 1913, p. 2.

163 BOA, HR.SYS, 147/65, M. 10.07.1911.

164 BOA, HR.SYS, 150/16, M. 26.12.1911.

165 BOA, BEO, 4016/301138, H. 26.03.1330 (15 Mart 1912). BOA, Meclis-i Vükela Mazbatalarl (MV), 162/73, H. 23.03.1330 (12 Mart 1912). 1 Eylül 1911 tarihli Tanin gazetesinde Tan gazetesinden yapılan iktibasla "İsa Bolatin" başlığıyla verilen haberde hükümete boyun eğerek Mitroviçe’ye dönen İsa'nın hükümetin kendisine sekiz bin lira vadettiğini iddia ettiği belirtilmiştir. Haberde taş ocağının da tekrar uhdesine ihale edilmesini isteyen İsa'nın "Genç Türkler bana emvalimin ve taş ocağımın iadesinden ve vaat olunan paranın tediyesinden istinkaf ediyorlar. Ben başka yerde para buldum; bunun kendilerine ne kadar pahalıya oturacağını düşünmek Jön Türklere ait bir meseledir.” şeklinde konuştuğu bilgisine de yer verilmiştir. "İsa Bolatin", Tanin, 1 Eylül 1911, s. 4.

166 BOA, BEO, 4041/303048, H. 03.06.1330 (20 May1s 1912).

167 “Arnavutluk'ta İhtiras”, Tercüman-ı Hakikat, 29 Haziran 1912, s. 2. İhsan Burak Birecikli, Arnavutlar ve Arnavutluk Sorunu 1908-1914, Gazi Üniversitesi Sosyal Bilimler Enstitüsü, Yayımlanmamış Doktora Tezi, Ankara, 2010, 312.

168 “The Albanian Troubles", The Scotsman, May 28, 1912, p. 7.

169 BOA, BEO, 4055/304069, H. 10.07.1330 (25 Haziran 1912). “Arnavutluk Ahvali -İsa Bolatin Ne Yap1yor-", Tercüman-ı Hakikat, 24 Haziran 1912, s. 3.

170 Mithat Aydın, “Arnavutluk’un Osmanlı Devleti’nden Kopuşu Sorunu (1912-1913)”, Belgi Dergisi, C. 2, S. 17 (Kış $2019 / \mathrm{I})$, s. 1104. 
Türklerin "lanetli ve nefret uyandıran politikası" yüzünden baş kaldırdıklarını, "imparatorluğun mahvını getirmekte olan Jön Türk yönetiminin denetim altına alınmayacak olursa sonunda yabancı güçlerin işgaline sebep" olacakları ifade edilmiştir. ${ }^{171}$ Aynı günlerde isyan, Mirdita bölgesi, Tiran ve İşkodra'yı içine alan Arnavutluk toprakları ile Kosova'nın çoğu yerine yayılmıştır. Temmuz sonuna kadar Priştine, Mitroviçe, Vulçitrin ve Firzovik ayaklanmacıların eline geçmiştir. ${ }^{172}$

İsa Bolatinî’nin faaliyetleri karşısında hükümet, onun Bolatin köyündeki kulesini yakmayı ve ailesini buradan uzaklaştırmayı alternatif bir tedbir olarak düşünmüştür. ${ }^{173} 3$ Temmuz'da etrafı yüksek tepelerle çevrili Bolatin köyüne doğru harekete geçen askerî birlikler köyü kuşatarak etrafında bazı tedbirler almışlardır. İsa Bolatinî'nin adamlarının attığı ilk kurşunla başlayan çatışma, yaklaşık on üç saat sürmüş ve neticede köyün etrafını saran tepeler büyük oranda askerler tarafından kontrol altına alınmıştır. ${ }^{174}$ Tercüman-1 Hakikat gazetesinin Rumeli gazetesinden iktibasla verdiği habere göre topçu ve piyade birlikleriyle yapılan ve 3 Temmuz gecesi başlayan bu müsademe kesintisiz bir şekilde on beş saat sürmüş, top mermileriyle tahrip edilen İsa'nın kulesi askerlerce ele geçirilmiştir. Çatışmalar esnasında eşkıyanın büyük bir kısmı öldürülürken çok az bir kısmı kaçabilmiştir. Kaçanlardan biri de avenesini terk ederek firar eden İsa Bolatinî olmuştur. Habere göre kanlı elbisesi müsademe mahallinde bulunmuştur. ${ }^{175}$

Belgrad'da yayımlanan Shtampa gazetesine göre İsa'nın çetesinde dört yüz kişi bulunuyordu ve o günlerde seksen kişi daha çeteye katılmıştı. İsa'nın etrafına çok sayıda adam toplamasının nedenlerinden biri çetesine katılmayanların evlerini yakmakla tehdit etmesiydi. Gazeteye göre isyana bölgedeki Sırpları da dahil etmek isteyen İsa, böylece Sırbistan ve Karadağ'ın da desteğini arkasına alabilecekti. ${ }^{176} \mathrm{Bu}$ arada İsa'nın Sırbistan'a firar eden Amel ve Tafel isimli oğulları, Sirplar tarafından oldukça iyi bir şekilde karşılanmışlardır. Üzerlerinde mavzer tüfekleri bulunan bu iki kardeşe Sırp subayları ile komitacılık eylemleriyle meşhur Yüzbaşı Philip refakat etmiştir. ${ }^{177}$ Belgrad Sefaretinin hükümete verdiği bilgiye göre İsa'nın oğulları tarafından satın alınan elli bin fişekten J.G.S markalı sekiz sandık Niş'e, M.D.Z markalı sekiz sandık da Leskovik'e sevk edilmiştir. Buralardan da Osmanlı hududuna sevk edilerek Arnavut asilere ulaştırılması planlanıyordu. ${ }^{178}$ Priştine Sancağındaki Arnavutların yüzde otuzunun sahip olduğu silahlar ile İsa Bolatinî'nin evinde ele geçirilen kasatura ve cephanelerin Sırbistan meşeli olması hudutta büyük bir silah kaçakçılığının varlığını göstermektedir. Öteden beri hudutta var olan zafiyetten dolayı görülen kaçakçılık olayları, Arnavutluk hadisesinden dolayı daha da artmıştır. Bunu engellemek için Hükümetçe Sırbistan nezdinde girişimde bulunulmasına karar vermişse de bundan bir sonuç alınabilmesi mümkün olmamıştır. ${ }^{179}$

İsyana iştirak eden Arnavut rüesası, hükümete ve askerî tertibata karşı ciddi bir vaziyet almış, Üsküp ve Mitroviçe arasındaki askerî nakliyatın durdurulmasını talep etmişlerdir. Eğer istekleri yerine getirilmezse hattı tahrip edecekleri tehdidini dile getirmekten de geri durmamışlardır. Genellikle Priştine, Mitroviçe, Gilan gibi kasabalarda toplanan isyancıların Firzovik ve havalisine

171 Malcolm, age., s. 303.

172 Malcolm, age., s. 304. BOA, HR.SYS, 151/1, M. 17.05.1912.

173 BOA, BEO, 4055/304100, H. 11.07.1330 (26 Haziran 1912).

174 BOA, HR.SYS, 151/52, M. 03.07.1912.

175 “Arnavutluk’ta İhtiras”, Tercüman-ı Hakikat, 29 Haziran 1912, s. 2.

176 BOA, HR.SYS, 151/60, M. 06.07.1912.

177 BOA, HR.SYS, 141/35, M. 17.07.1912. BOA, HR.SYS, 151/73, M. 17.07.1912.

178 BOA, HR.SYS, 151/97, M. 16.08.1912.

179 BOA, HR.SYS, 141/41, M. 02.09.1912. 
ilerlerken Üsküp ve belki Selanik'e doğru ilerleyebilecekleri yönünde tahminler de söz konusu olmuştur. Ancak 24 Temmuz gecesi İsa ve avenesi Yenipazar'1 işgal etmişlerdir. ${ }^{180}$ İsyan boyunca birlikte harekat eden Rıza Bey, Bayram Curri ve İsa Bolatinî, 16 Ağustos'ta Üsküp’ü işgal etmişlerdir. ${ }^{181}$

Bu dönemde İsa ve Rıza Bey bir yandan İngiliz yanlısı bir politika takip ederek İngiltere'nin desteğini almaya çalışırlarken bir yandan da Selanik’te bulunan II. Abdülhamid'i tekrar tahta çıarmak gibi bir düşüncenin içerisine girmişlerdir. ${ }^{182}$ Eğer bunu başaramazlarsa en azında Rumeli'de kuracakları bir devletin Padişahı yapmayı planlamışlardır. ${ }^{183}$ Hüseyin Cahit, İsa Bolatinî’nin II. Abdülhamid'i tekrar tahta çıkarmak istemesini şu şekilde değerlendirmiştir: "İsa Bolatin Şale kabilesinden pespaye bir adamdır ki asil olmadığı için Arnavutlar nezdinde hiçbir zaman bir baş gibi telakki edilemez. Abdülhamid'den 60 lira maaş alan ve Meşrutiyetten sonra bu maaşı kesilen İsa Bolatin'in en birinci arzusu eski yağma devrinin iadesidir." ${ }^{184} \mathrm{Bu}$ iki gelenekçi Arnavut'un Selanik'e ilerleyerek II. Abdülhamid'i tahta çıarma teşebbüsünde bulanabilecekleri tehdidi karşısında hükümet, üzerinde yapılan ufak değişikliklerle Hasan Priştine'nin On Dört Maddesini kabul etmek zorunda kalmıştır. ${ }^{185}$ Böylece 20 Ağustos itibariyle 1912 Arnavutluk ayaklanması sona ermiştir. ${ }^{186}$

Ağustos ayı sonunda İsa ile görüşen İngiliz diplomat Aubrey Herbert, aralarında geçen konuşmayı anılarında şu şekilde ifade etmiştir:

“'Arnavutlar otonomi istiyorlar mı?' diye sordum 'Hayır, istemiyorlar, onların istediği tek şey işlerine fazla karışılmaması' diye cevap verdi. 'Birleşmeyi istiyor musunuz?' sorumu ise şöyle cevaplandırdı: 'Kuzeyle Güney arasında mı? Pekâlâ, biz tek bir halkız' fakat sonra birleşmenin Kuızey'in yararına olmayacağını çünkü Güneyli Toskların Kuzeylilerden daha zeki ve tahsilli oldukların söyledi. Arnavutlar sultanın yönetimi altında kalmak istiyorlardl fakat kendilerini ve ülkelerini savunmak için silaha sahip olmaliydılar... Kendi hesabina Sultanı takdir ediyor ve onun hakimiyetinden ayrlmayl arzu etmiyordu. Ayrlldiklarl takdirde onlarl Sirp veya Karadağ boyunduruğundan başka ne bekliyordu." 187

Balkan Savaşı'nda İsa Bolatinî’nin Faaliyetleri

Arnavutlar, Gazi Ahmed Muhtar Paşa hükümetiyle büyük oranda anlaşmış olsalar da 8 Ekim'de Karadağ' 1 17 Ekim'de Surbistan ve Bulgaristan'1n, 19 Ekim'de de Yunanistan'1n Osmanl1 Devleti'ne savaş ilanıyla birlikte başlayan Balkan Harbi, sürecin başka bir boyuta evirilmesine neden olmuştur. Balkan ülkeleri arasında oluşan ittifak ağının merkezi haline gelen Sırbistan, 1912 yazı boyunca Kosova bölgesindeki hem Sırplara hem de nüfuz ve denetimi altına alabileceğini

180 BOA, BEO, 4067/305002, H. 16.08.1330 (31 Temmuz 1912). “Crisis in Turkey”, Gippsland Times, August 8, 1912 , p. 3.

181 “An Ultimatum to Albanians", The Scotsman, 20 August 1912, p. 5. "Albanian Affairs”, Army and Navy Gazette, 24 August 1912, p. 793-94. “Turkish Troubles”, Belfast Evening Telegraph, August 22, 1912, p. 5.

182 BOA, BEO, 4113/308453, H. 06.12.1330 (16 Kasim 1912).

183 Fevzi Çakmak, Batı Rumeli'yi Nasıl Kaybettik?, Yay. haz. Ahmet Tetik, Türkiye İş Bankası Kültür Yay., 2. Baskı, İstanbul,

2012, s. 116. Sacit Kutlu, Milliyetçilik ve Emperyalizm Yüzyılında Balkanlar ve Osmanlı Devleti, İstanbul Bilgi Üniversitesi

Yay., 2. Bask1, İstanbul, 2018, s. 289.

184 Hüseyin Cahit, “Arnavutluk ve İttihat Terakki 2”, Tanin, 17 Eylül 1912, s. 1.

185 Malcolm, age., s. 306.

186 Aydın, agm., s. 1111.

187 Aubery Herbert, Ben Kendim Osmanlı Ülkesine Son Seyahat, çev. Y1lmaz Tezkan, 21. Yüzyıl Yay., Ankara, 1999, s. $155-156$. 
düşündüğü Arnavut reislerine silah taşımıştır. Bir yandan Arnavutları silahlandırırken bir yandan da savunmasız haldeki Sırplara karşı “Arnavut kanunsuzluğundan yakınarak” propaganda faaliyetinde bulunmuştur. Bu dönemde Sırbistan temsilcileri Bayram Curri ve Necip Draga ile görüştükleri gibi Sırplara yakınlığıyla tanınan İsa Bolatinî ile de temasa geçmişlerdir. Onunla görüşen isimlerden biri milliyetçi "Kara El”" hareketinin "kötü şöhretli üyelerinden” Albay Apis olmuştur. 1912 yılının Ağustos ve Eylül aylarında ona büyük miktarda silah teslim eden Sırbistan'ın her ay yüklü miktarda ödeme yaptığı da söylentiler arasında yer alıyordu. Ancak gerçekler söylentilerin tam aksi yönünde seyretmiş ve İsa “öyle kolay satın alınacak bir adam” olmadığını göstermiştir. ${ }^{188}$

16 Ekim'den itibaren Sırp ordusu Kosova'da ilerlemeye başlarken binlerce silahlı Arnavut, topraklarını korumak için en ön saflarda yer almaya çalışmıştır. 16 Ekim'de Fransız konsolosu “halk arasındaki söylentilere göre Sırbistan tarafından satın alınmış" olan İsa'nın Sırbistan'a karşı oldukça etkili bir kampanya yürüttüğü ve bu çerçevede bin kadar Arnavut'a Mauser tüfekleri dağıttığını bildiriyordu. Aynı şekilde Sırbistan Üçüncü Ordusu karargahında bulunan bir Sırp gazeteci, Bolatinî'nin adamlarının Kosova'nın kuzeydoğusunda güçlü bir direniş gösterdiklerini haber vermiştir. Sırpların 22 Ekim'de Priştine'yi ele geçirmesi üzerine İsa, daha fazla kuvvet toplamak için Mitroviçe'ye gitmiştir. Bu sırada oranın da Sırp saldırısına uğraması üzerine önce Yakova'ya oradan Prizren'e geçerek sonunda Arnavutluk'a çekilmek zorunda kalmıştır. ${ }^{189}$

Tüm bunlara rağmen İngiliz basınında on bin adamı olduğu söylenen İsa'nın Sırbistan'ın yanında olduğunu açıklamasının beklendiğine yönelik haberler çıkmıştır. Osmanlı Devleti'nin Arnavutluk'taki durumu ve geleceği için önemli bir yere sahip olduğu ifade edilen bu açıklamanın aynı zamanda Sırpları Üsküp'e doğru ilerleyişlerinde daha avantajlı kılacaktı. ${ }^{190}$ Aynı günlerde gazetelerdeki haberlerde İsa'nın iyi teçhiz edilmiş iki yüz Arnavut'la General Zivkovic'in komutasındaki Sırp ordusuna katıldığı ifade edilmiştir. ${ }^{191}$ Kasım ayının ilk günlerinde ise İsa'nın on beş bin Arnavut ile Sirplara teslim olduğu haberi duyurulmuştur. ${ }^{192}$

Bu dönemde zaman zaman İsa’nın öldüğüne dair asılsız haberler çıkmıştır. Bunlar, bir ölüm haberinden ziyade efsane bir ismin trajik ölüm hikayesini andırıyordu. 31 Ekim 1912'de Evening Telegraph and Post gazetesinde "Death of a Brigand" başlığıyla verilen haberde Yenipazar Sancağındaki Sırp kuvvetlerine katılan İsa'nın General Zivkovic ile anlaşmazlığa düştüğü tartışırlarken silahına davrandığı ancak ondan daha hızlı olan General tarafından vurularak öldürüldüğü bildirilmiştir. ${ }^{193}$

Kosova bölgesinde başlayan Sırp işgaliyle birlikte Müslüman Arnavutlara karşı büyük bir katliam ve zulüm başlamıştır. Kaçak adı verilen Arnavut isyancılardan oluşan küçük çeteler, Sırplara karşı direniş göstermeye çalışmışlarsa da bunlar şiddetli bir şekilde etkisiz hale getirilmiştir. ${ }^{194} \mathrm{Bu}$

188 Malcolm, age., s. 307-308.

189 Malcolm, age., s. 309.

190 Dublin Daily Express, October 23, 1912, p. 10. "Men of the Moment", Belfast Telegraph, October 25, 1912, p. 3.

191 “A Dreaded Bandit”, Aberden Press and Journal, October 21, 1912, p. 7. “An Albanian Outlaw”, Belfast Telegraph, October 25, 1912.

192 "Famous Arnaut Chief Surrenders", The Scotsman, November 4, 1912, p. 8. "15.000 Arnauts Surrender", Birmingham Daily Gazette, November 4, 1912, p. 5. "The War in the Balkans", Montrose, Arbroath and Brechin Review, November 8, 1912.

193 "Death of a Brigand”, Evening Telegraph and Post, October 31, 1912, p. 4. "Brigand's Death”, Globe, October 31, 1912 , p. 8. “Albanians Leader's End”, Globe, October 31, 1912, p. 10. “A Famous Freebooter's Death”, Dundee Courier, November 7, 1912, p. 8.

194 Malcolm, age., s. 316. 
dönemde İsa Sırp ve Karadağ kuvvetlerine karşı silah teminine çalışırken ${ }^{195} 1913$ yılının Eylül ayında Luma bölgesiyle Yakova'nın batısındaki dağlarda büyük bir ayaklanma örgütlenmişti. İsa Bolatinî, Bayram Curri ve diğer Arnavut liderler ayaklanmanın başına geçmişlerse de Sırplar, ibret olması için Yakova' da Arnavut ileri gelenlerinden birçoğunu kurşuna dizerek öldürmüşlerdir. ${ }^{196} 24$ Eylül tarihli Aberden Press and Journal gazetesinin Neue Freie Presse gazetesine dayandirarak verdiği habere göre İsa Bolatinî komutasındaki binlerce Arnavut Debre yakınlarındaki Sırp topraklarına girmeye çalışmışlar ancak Sırplar tarafından geri püskürtülmüşlerdir. Arnavutlar bu taarruz esnasında iki yüz kadar kayıp vermişlerdir. Gazetenin aktardığı habere göre sınırı geçen 170 Arnavut bir gün içerisinde öldürüldüğü gibi bütün Arnavut ileri gelenleri ve çocukları ya tutuklanmış ya da öldürülmüştür. ${ }^{197}$

Lev Troçki, savaş esnasında görüştüğü Sırp askerlerin dilinden Arnavutların Sırplara karşı mücadelesini ve bunun neticesinde Arnavutlara karşı yapılan zulümlerin nasıl başladığını şu şekilde anlatmıştır:

“İsa Boletini’nin să̆ kollarından biri olan İdris Seferi’nin idaresinde yaklaşık bin Arnavut karşımızda bulunuyordu. Ellerinde Arnavut isyanı [1909] sırasında bizim onlara sağladığımı Martinler ve seri ateş eden Sırp tüfekleri vardı. O zaman bizden para da almışlardı. Ĕ̆er savaş olursa, bizim yanımızda saf tutmalarını sağlamak istemiştik. Ama tersi oldu. Bizim silahlarımızla donanmış Arnavutlar, bizim mevzilerimize ilk saldıranlar oldu ve kolayca üstünlüğü elde ettiler. Niye bu böyle olmuştu? Türkiye’yle dini bă̆ da rol oynadı tabii, ama asıl neden, Arnavutların şunu kavramış olmalarıyd: Kendilerini tehdit eden şey, Arnavutluk'un Sırbistan ile Yunanistan arasında bölünmesiydi ve tarlalarını, evlerini, sürülerini savunmak zorundaydılar. Kırllan umutlar (Bu da ne? Kendi silahlarımızı, kendi paramızı bize karşı kullanıyorlar?) ordumuzu iyiden iyiye kızdırdı. Bu yapılan zulümlerin, girişilen gaddarca eylemlerin esas sebebiydi..." 198

14 Ekim'de İsa, büyük bir Arnavut birliği ile Gusine ve Yakova arasındaki hat boyunca Karadağ sınırına saldırılar düzenlemiştir. İki gün süren şiddetli çatışmalardan sonra Arnavutlar geri çekilmek zorunda kalmışlardır. ${ }^{199}$ Arnavutlar, 28 Kasım 1912'de İsmail Kemal Bey önderliğinde Arnavutluk'un bağımsızlığını ilan ederek geçici bir hükümet kurmuşlardır. Devlet Başkanlığı ve D1ş İşleri Bakanlığ 1 görevlerini üstlenen İsmail Kemal Bey, ${ }^{200}$ kurduğu yeni hükümeti ve düzeni korumak, olası Sırp, Yunan ve Osmanlı saldırılarına karşı kendilerini savunmak için kendi silahlı kuvvetlerini kurmuştur. Oluşturulan Milli Kuvvetlerin başına Osmanlı ve Sırp kuvvetlerine karşı savaşarak önemli bir deneyim kazanmış olan, iki Kosovalıyı, Rıza Bey ve İsa Bolatinî’yi getirmiştir. ${ }^{201}$

İsmail Kemal Bey, 1913 yılının Şubat ayında beraberindeki kalabalık bir heyetle Arnavut

195 "Efforts to Stir Up Albanian Tribes", The Scotsman, August 13, 1913, p. 9.

196 Malcolm, age., s. 316. "The Albanian Difficulty”, Army \&Navy Gazette, September 27, 1913, p. 1-2.

197 "Dangerous Situation in Albania", Aberden Press and Journal, September 24, 1913, p. 6.

198 Lev Troçki, Balkan Savaşları, çev. Tansel Güney, Türkiye İş Bankası Kültür Yay., 1. Baskı, İstanbul, 2012, s. 163-164.

199 “The Balkans", The Mercury, October 18, 1913, p. 5.

200 İhsan Burak Birecikli, Avlonyalı İsmail Kemal Bey’in Bağımsızlık Mücadelesi 1912- 1914, Journal of History School, 41 (2019), 602.

201 Krisztián Csaplár-Degovics, “The Policy of the Qemali Government Between December 1912 and April 1913”, In: ANNUARIO - Albanian Yearbook for historical and anthropological studies / Vjetari shqiptar për studimet historike dhe antropologjike. Tirana 2014, p. 9. "Albania”, Sheffield Daily Telegraph, December 7, 1912, p. 9. 
Meselesini duyurmak ve destek aramak için uzun bir Avrupa seyahatine çıkmıştır. Heyetin en önemli üç ismi İsmail Kemal, Luigj Gurakuqi ve İsa Bolatinî idi. İsmail Kemal Bey seyahate Edhem ve Kazım isimli iki oğlu ile katılırken İsa Bolatinî'nin yanında yedi oğlu bulunuyordu. ${ }^{202}$ Yerel kıyafetleri içerisindeki İsa, Roma, Viyana, Paris ve Londra gibi Avrupa başkentlerinde oldukça dikkat çekmiştir. Viyana'da bulunduğu günlerde Avusturya Dişişleri Bakanlığına kabul edilmiş, Genelkurmay Başkanı ve Savaş Bakanı ile görüşerek askerî durum ve olası bir iş birliği hakkında görüşmeler yapmıştır. ${ }^{203}$

17 Aralık 1912 - 11 Ağustos 1913 tarihleri arasında gerçekleşen Büyük Elçiler Konferansı ${ }^{204}$ devam ederken Londra' ya ulaşan heyet burada oldukça iyi bir şekilde karşılanmıştır. Heyet üyeleri her ne kadar konferansta tartışılan konularda söz sahibi olamasalar da İngiliz Dışış̧leri Bakanı Grey ve Üçlü İttifak temsilcileri ile serbestçe temasa geçebilme imkânı bulmuşlardır. Hotel Cecil'de konaklayan Arnavutlar, geleneksel kıyafeti, kemerindeki hançer ve tabancalarıyla İsa sayesinde Londralıların dikkatini çekebilmişlerdir. ${ }^{205}$

Aubrey Herbert'e göre Arnavut heyetinin en dikkat çekici siması “Arnavutluk'un Robin Hood'u" olarak nitelendirdiği İsa Bolatinî olmuştur. Londra'da bulunduğu günlerde zamanının çoğunu Herbert'in evinde kahve içerek geçiren İsa, Loyd George ile de görüşmüştür. Herbert, tercümanlık yaptığı görüşmeyi anılarında şu şekilde anlatmıştır:

“Ísa Bey 'Ona söyle’ dedi, 'Ben bir dağllyım, o da öyle, ben inanıyorum ki onun kalbi acı çekenlere karşı çok hassastır.' Ve sözlerini biraz da kızgınlıkla şöyle bitirdi: 'Ve söyle ki bahar geldiğinde Kosova ovasını Sırpların ölüleri ile gübreleyeceğiz, çünkü biz Arnavutlar unutamayacak kadar çok acı çektik.' Son cümleyi biraz yumuşatmanın akıllıca olacă̆ını düşündüm, fakat Mr. Lloyd George bu uzun dağlıdan hoşlanmış, onda yüksek bir ruh olduğunu fark etmiş ve ona nazik olmuştur. "206

İsa'nın Londra'daki günleriyle ilgili en dikkat çekici anekdotlardan biri İngiliz Dışişleri Bakanlığında Edward Grey'e yapmış olduğu ziyarettir. Edwin Jacques'in aktardığı anekdota göre Bakanlık girişinde üzerindeki silahları bırakması istenen İsa hiç itiraz etmeksizin silahlarını görevliye teslim etmiştir. Görüşme sonunda ona girişe kadar eşlik eden bakan, gülerek "General, yarın gazeteler Mahmut Şevket Paşa'nın silahsızlandıramadığı İsa Bolatinî'nin Londra'da silahsızlandırıldığını yazacak." demiştir. İsa, gülerek "Londra' da da değil." şeklinde cevap verirken cebinden ikinci bir silah çıkarmıştır. ${ }^{207}$

O günlerde II. Meşrutiyetin ilanı sürecinde önemli bir rol üstlenmiş olan Kahraman-1 Hürriyet Resneli Niyazi 30 Nisan 1913 ’te Avlonya limanında öldürülmüştür. ${ }^{208}$ Gazetelerde suikastla ilgili

202 Csaplár-Degovics, agm., s. 16

203 “Austria to Reduce”, Dundee Courier, April 21, 1913, p. 4. "The Albanian Question”, Northern Whig, April 21, 1913 , p. 12. Csaplár-Degovics, agm., s. 16.

204 Konferansta Arnavutluk'un geleceği hakkında yapılan görüşmeler için bk. Necdet Hayta, Balkan Savaşları'nın Diplomatik Boyutu ve Londra Büyükelçiler Konferansı (17 Aralık 1912 - 11 Ağustos 1913), AKDTYK Atatürk Araştırma Merkezi Yay., Ankara, 2008, s. 63-73.

205 Csaplár-Degovics, agm., s. 17.

206 Herbert, age., s. 158.

207 Edwin E. Jacques, The Albanians: An Ethnic History from Prehistoric Times to the Present, McFarland \& Co., Jefferson, N.C., 1995, p. 339.

208 “Reported Assassination of Niazi Bey”, Yorkshire Post and Leeds, May 1, 1913, p. 8. 
haberlerde İsa Bolatinî'nin azmettirici olduğu da ifade ediliyordu. ${ }^{209}$ Hatta Londra'da 'Niyazi'nin Katili İsa Bolatinî’nin Oğludur!" yazılı pankartlarla protesto edilmiştir. Herbert, İsa'ya bunun doğru olup olmadığını sorduğunda şu cevabı almıştır: “... büyük bir ihtimalle doğrudur. Oğlumun Niyazi’yi öldürmeye, Niyazi’nin onu öldürmeye olduğu kadar kararlı olduğunu biliyordum."’10 Olayla ilgili en dikkat çekici iddiayı dile getiren ise dönemin şahitlerinden Avlonyalı Ekrem Bey olmuştur. Ekrem Bey, İsa Bolatinî ile 1908 yılında Manastır'da katledilen Şemsi Paşa'nın kan kardeşi olduklarını oğullarının da bunun intikamını almak ve babalarının şerefini korumak için -her ne kadar olayın faili olmasa bile Jön Türklerin ileri gelenlerinden olduğu için- Niyazi Bey’i katletmişlerdir. ${ }^{211}$

Olayın faillerinin İsa Bolatinî ile Yakovalı Malisör Şaban Batak'ın akrabaları olduğunun tespit edildiğini belirten Kazım Karabekir, yakınlık dereceleri hakkında bir malumat vermemiştir. Ona göre, Avlonya hükümeti failleri yakalamamıştır ancak sığındığı Podgoriçe'de Karadağlılar tarafindan katledilen İsa, "layık olduğu cezayı" bulmuştur. ${ }^{212}$ Niyazi Bey'i şehit edenlerin isimleri ve İsa Bolatinî ile akrabalık derecelerini belirten ise Avlonyalı Süreyya Bey olmuştur. Ona göre "arkasından nâmerdane atılan iki kurşun ile" hayatına son verilen Niyazi'ye "kurşunları sıkan eller İsa Ağa Boletin'in biraderzadesi Yunus Boletin ile rüfekâsından Bayram idi.”’213

\section{İsa Bolatinî’nin I. Dünya Savaşı'ndaki Faaliyetleri ve Ölümü:}

Avusturya-Macaristan İmparatorluğu'nun 28 Temmuz 1914'te Sırbistan'a savaş ilanıyla başlayan I. Dünya Savaşı, Arnavutların ve İsa Bolatinî’nin Sırbistan'a ve Karadağ'a karşı mücadelesinde yeni bir başlangıç oluşturmuştur. Ağustos başında Arnavutlar, Sırbistan tarafindan işgal edilen topraklarını geri almak için birleşirlerken İsa da Sırbistan topraklarına güneyden girmek için operasyonlar başlatmıştır. ${ }^{214}$

Aralık ayına gelindiğinde İsa Bolatinî ve Prenk Bib Doda'nın da aralarında bulunduğu bir grup Müslüman Arnavut, İşkodra'da bir araya gelerek Sırbistan ve Karadağ'a karşı savaşma kararı almışlardır. Dikkat çekici bir şekilde toplantı esnasında Halife tarafından ilan edilen Cihad-1 Mukaddes'e katılıp katılmama konusu da tartışılmış; İsa, halifenin çağrısına uyma noktasında 1srarcı davranmıştır. ${ }^{215}$

1915 Haziran'ı sonlarında İsa Bolatinî, Rıza Bey, Bayram Curri ve onlara katılan bir Avusturyalı

209 "Well-known Turk Murdered", Aberden Press and Journal, May 1, 1913, p. 8. "Turk Leader Murdered”, Manchester Courier and Lancashire General Advertiser, May 2, 1913, p. 18. "Niazi Bey Assassinated”, Examiner, May 2, 1913, p. 5. "Turkish Bey Assassinated”, Daily Post, May 2, 1913, p. 5. "Reported Assassination of Niazi Bey”, The Scotsman, May 1, 1913, p. 7. Suikast sonrası Avlonya halkı Semim Nehri yakınlarında yirmi beş bin kişilik askeri birliğin başında bulunan Cavit Paşa'nın arkadaşının intikamını almak için şehre geleceğinden korkmaya başlamıştır. Öyle ki İtalyan konsolos hükümetinden gecikmeksizin İtalyan menfaatlerinin korunması için savaş gemilerinin gönderilmesini istemiştir. Manchester Courier and Lancashire General Advertiser, May 1, 1913, p. 7.

210 Herbert, age., s. 160.

211 Avlonyalı Ekrem Bey, age., s. 232.

212 Karabekir, age., s. 635-636. Külçe, Osmanlı..., s. 440.

213 Avlonyalı Süreyya Bey, Osmanlı Sonrası Arnavutluk (1912-1920), Yay. haz. Abdulhamit Kırmızı, Klasik Yay., İstanbul, 2009, S. 393.

214 “Albania Against Servia”, Coventry Evening Telegraph, August 5, 1914, p. 3. "Albania Against Servia”, Gloucestershire Echo, August 5, 1914, p. 5. "Albanians United Against Servia”, Western Times, August 6, 1914, p. 4.

215 “Turkey's Declaration of Holly War", Arberdeen Press and Journal, December 3, 1914, p. 6. "War Wires”, Birmingham Daily Gazette, December 3, 1914, p. 1. 
subayla kumanda ettikleri dört bin kişiyle birlikte Diakovitsa Geçidinden Karadă̆ sınırına bir saldırı gerçekleştirmişlerdir. Arnavutları püskürtmek için Karadağ’ın gönderdiği birliğin yarısına yakını yaralanmış veya ölmüştür. ${ }^{216}$ Temmuz ayına gelindiğinde gazeteler, İsa'nın adamlarıyla birlikte Karadağ'a teslim olduğunu ve Kralın onun Çetine'de enterne edilmesini emrettiğini haber vermiştir. $^{217}$

22 ve 23 Kasım 1915 tarihinde yayımlanan İngiliz gazetelerinde İsa’nın öldüğü haberlerine yer verilmiştir. ${ }^{218}$ Böylece Balkan Harbi'nde farklı tarihlerde öldügüne dair çıkan haberlere Cihan Harbi'nde de rastlanmaya başlanmıştır. Fakat bu haberlerin birer asparagastan ibaret olduğu çok kısa bir süre sonra anlaşılmıştır. Ancak her canlı gibi İsa için de kaçınılmaz son 23 Şubat 1916'da Podgoriçe'de Karadağlılar ile Arnavutlar arasında çıkan bir çatışmada oğluyla birlikte öldürülmesiyle gelmiştir. ${ }^{219}$

\section{Sonuç}

İsa Bolatinî’nin daha on yedi yaşında olduğu 1881 yılında Arnavutluk topraklarını savunmak için başladığı mücadelesi, otuz beş yıl sonra elli iki yaşında olduğu 1916 yılında ölümüyle sona ermiştir. Zikzaklarla dolu hayatı boyunca eylemleri ve faaliyetleri nedeniyle bir dönem merkezî otoriteyle karşı karşıya gelmiş "eşkıya" olarak nitelendirilmiş bir dönem yaşadığı bölgede saltanata ve devlete hizmeti görüleceği düşünülerek ihsanlara ve lütuflara mazhar olarak "bey" unvanıyla anılmıştır. Müesses nizamın bozulmasıyla birlikte değişen dengelere ve meydana gelen gelişmelere bağlı olarak yeni rejim ve onun temsilcileriyle uzun bir çatışmanın içerisine girmiştir.

1909 yılından itibaren 1912 yılına değin her yıl art arda yaşanan Arnavut isyanlarında az çok etkisi bulunan İsa Bolatinî, Balkan Harbi’nin başlamasıyla birlikte milliyetçi bir tavra bürünmüş işgal edilen vatan topraklarını işgal kuvvetlerine karşı savunmak için uzun soluklu bir mücadelenin içerisine girmiştir. İsyanlardaki rolüyle Avrupa kamuoyu tarafından tanınmaya başlanan İsa, Balkan Savaşı'nda gösterdiği cesaretle daha bilinir hale gelmiştir. Londra Büyük Elçiler Konferansı nedeniyle bulunduğu Londra'da yerel kıyafetleriyle dolaşan İsa hem devlet adamları hem de İngiliz kamuoyu nezdinde oldukça itibar görmüştür. I. Dünya Savaşı'nda Arnavutluk toprakları uğruna savaşırken esir düştüğü Podgoriça' da öldürülen İsa Bolatinî, Arnavutluk ve Arnavutlar için verdiği mücadele ile millî bir kahraman haline gelmiştir.

\section{KAYNAKLAR}

\section{Arşiv Belgeleri}

Cumhurbaşkanlığg Devlet Arşivleri Başkanlığı Osmanlı Arşivi (BOA)

\footnotetext{
216 “Austria's Allies”, Northern Whig, June 28, 1915, p. 7. “Albanians Crushed”, Sheffield Daily Telegraph, June 28, 1915, p. 8. "Montenegrins Repulse Albanians", The Scotsman, June 28, 1915, p. 8. “Austria's Allies”, Londonderry Sentinel, June 29, 1915, p. 6.

217 "Campaign in Albaina", Manchester Courier and Lancashire General Advertiser, July 9, 1915, p. 8.

218 Manchester Evening News, November 22, 1915, p. 5. "Death of Famous Albanian Chief", Aberden Press and Journal, November 23, 1915, p. 6. "Death of a Famous Albanian Chief”, The Scotsman, November 23, 1915, p. 8. "The Man who Defied Abul Hamid", The Liverpoll Echo, November 23, 1915, p. 7.

219 "Queer Montenegrins", Western Daily Press, January 26, 1916, p. 10. "Encourters at Podgoritza”, Portsmouth Evening News, January 26, 1916, p. 8. “Austrians in Montenegro”, Falkirk Herald, January 26, 1916, p. 3. Avlonyalı Süreyya Bey, age., s. 420.
} 
Babıali Evrak Odası Evrakı (BEO),

Dahiliye Nezareti Mektubî Kalemi (DH.MKT)

Dahiliye Nezareti Muhaberat-1 Umumiye İdaresi Evrakı (DH.MUİ)

Dahiliye Nezareti Şifre Kalemi (DH.ŞFR)

Hariciye Nezareti Siyasi (HR.SYS)

İrade Orman ve Maadin (İ.OM)

İrade Taltifat (İ.TAL)

Meclis-i Vükela Mazbataları (MV)

Rumeli Müfettişliği Arzuhaller (TFR.I.ŞKT)

Rumeli Müfettişliği Jandarma Müşiriyet ve Kumandanlık Evrakı (TFR.I.AS)

Rumeli Müfettişliği Kosova Evrakı (TFR.I.KV)

Rumeli Müfettişliği Makamat Evrakı (TFR.I.MKM)

Rumeli Müfettişliği Müteferrika Evrakı (TFR.I.M)

Rumeli Müfettişliği Sadaret Evrakı (TFR.I.A)

Yı1dız Esas Evrakı (Y.EE)

Yıldız Mütenevvi Maruzat Evrakı (Y.MTV)

Yıldız Perakende Evrakı Arzuhal Jurnal (Y.PRK.AZJ)

Yıldız Perakende Evrakı Askeri Maruzat (Y.PRK.ASK)

Yıldız Perakende Sadaret Maruzatı (Y.PRK.A)

Yı1dız Sadaret Hususi Maruzat Evrakı (Y.A.HUS)

\section{Resmi Yayınlar}

Meclis-i Mebusan Zabıt Ceridesi, İçtima: 13, 25 Teşrinisani 1326 (8 Aralık 1910), C. 3.

\section{Gazeteler}

“15.000 Arnauts Surrender”, Birmingham Daily Gazette, November 4, 1912, p. 5.

“A Dreaded Bandit”, Aberden Press and Journal, October 21, 1912, p. 7.

“A Famous Freebooter's Death”, Dundee Courier, November 7, 1912, p. 8.

“Albania Against Servia”, Coventry Evening Telegraph, August 5, 1914, p. 3.

“Albania Against Servia”, Gloucestershire Echo, August 5, 1914, p. 5.

“Albania”, Sheffield Daily Telegraph, December 7, 1912, p. 9. 
“Albanian Affairs”, Army and Navy Gazette, August 24, 1912, p. 793-94.

“Albanian Chief Issa Bolitenatz A Picturesque Warrior”, Saturday Mail, June 21, 1913, p. 2.

“Albanian Chief Issa Bolitenatz”, Saturday Mail, June 21, 1913, p. 2.

“Albanian Chief”, Saturday Mail, June 21, 1913, p. 2.

“Albanian Revolt”, Dublin Daily Express, August 31, 1909, p. 8.

“Albanians Crushed”, Sheffield Daily Telegraph, June 28, 1915, p. 8.

“Albanians Leader's End”, Globe, October 31, 1912, p. 10.

“Albanians United Against Servia”, Western Times, August 6, 1914, p. 4.

“An Albanian Brigand The Career of Issa de Boletini”, The Mercury, December 14, 1912, p. 9.

"An Albanian Outlaw”, Belfast Telegraph, October 25, 1912.

"An Ultimatum to Albanians", The Scotsman, August 20, 1912, p. 5.

“Arnavutluk Ahvali Hakkında Cavit Paşa ile Mülâkât”, Yeni Tasvir-i Efkâr, Nu: 50, 19 Temmuz 1909, s. 2.

“Arnavutluk Ahvali -İsa Bolatin Ne Yapıyor-”, Tercüman-1 Hakikat, 24 Haziran 1912, s. 3.

“Arnavutluk’ta İhtiras”, Tercüman-1 Hakikat, 29 Haziran 1912, s. 2.

“Austria to Reduce”, Dundee Courier, April 21, 1913, p. 4.

“Austria’s Allies”, Londonderry Sentinel, June 29, 1915, p. 6.

“Austria’s Allies”, Northern Whig, June 28, 1915, p. 7.

“Austrians in Montenegro”, Falkirk Herald, January 26, 1916, p. 3.

“Brigand's Death”, Globe, October 31, 1912, p. 8.

"Campaign in Albaina", Manchester Courier and Lancashire General Advertiser, July 9, 1915, p. 8.

“Crisis in Turkey”, Gippsland Times, August 8, 1912, p. 3.

"Dangerous Situation in Albania", Aberden Press and Journal, September 24, 1913, p. 6.

"Death of a Brigand", Evening Telegraph and Post, October 31, 1912, p. 4.

“Death of a Famous Albanian Chief”, The Scotsman, November 23, 1915, p. 8.

“Death of Famous Albanian Chief”, Aberden Press and Journal, November 23, 1915, p. 6.

"Efforts to Stir Up Albanian Tribes", The Scotsman, August 13, 1913, p. 9.

“Encourters at Podgoritza”, Portsmouth Evening News, January 26, 1916, p. 8.

"Famous Arnaut Chief Surrenders", The Scotsman, November 4, 1912, p. 8.

“Galip Paşa'nın Hâtıraları”, Hayat Tarih Mecmuası, Yı1: 2, C. 1, S. 6 (Temmuz 1966), s. 8-11. 
“İsa Bolatin”, Tanin, 1 Eylül 1911, s. 4.

"Men of the Moment", Belfast Telegraph, October 25, 1912, p. 3.

“Montenegrins Repulse Albanians", The Scotsman, June 28, 1915, p. 8.

“Niazi Bey Assassinated”, Examiner, May 2, 1913, p. 5.

“Queer Montenegrins”, Western Daily Press, January 26, 1916, p. 10.

“Reported Assassination of Niazi Bey", The Scotsman, May 1, 1913, p. 7.

"Reported Assassination of Niazi Bey”, Yorkshire Post and Leeds, May 1, 1913, p. 8.

“The Albanian Difficulty”, Army \&Navy Gazette, September 27, 1913, p. 1-2.

“The Albanian Question”, Northern Whig, April 21, 1913, p. 12.

"The Albanian Troubles", The Scotsman, May 28, 1912, p. 7.

"The Balkan States", London Evening Standard, October 3, 1902, p. 5.

"The Balkans", The Mercury, October 18, 1913, p. 5.

"The Man who Defied Abul Hamid", The Liverpoll Echo, November 23, 1915, p. 7.

"The War in the Balkans", Montrose, Arbroath and Brechin Review, November 8, 1912.

"Turk Leader Murdered", Manchester Courier and Lancashire General Advertiser, May 2, 1913, p. 18.

“Turkey's Declaration of Holly War”, Arberdeen Press and Journal, December 3, 1914, p. 6.

“Turkish Bey Assassinated”, Daily Post, May 2, 1913, p. 5.

“Turkish Troubles”, Belfast Evening Telegraph, August 22, 1912, p. 5.

"War Wires", Birmingham Daily Gazette, December 3, 1914, p. 1.

“Well-known Turk Murdered”, Aberden Press and Journal, May 1, 1913, p. 8.

Dublin Daily Express, October 23, 1912, p. 10.

Hüseyin Cahit, “Arnavutluk ve İttihat Terakki 2", Tanin, 17 Eylül 1912, s. 1.

Manchester Courier and Lancashire General Advertiser, May 1, 1913, p. 7.

Manchester Evening News, November 22, 1915, p. 5.

\section{Kitap ve Makaleler}

Alkan, Necmettin, Mutlakıyetten Meşrutiyete II. Abdülhamid ve Jön Türkler, Selis Kitaplar, 1. Bask1, İstanbul, 2009.

Andonyan, Aram, Balkan Savaşı, çev. Zaven Biberyan, Aras Yayıncılık, 2. Baskı, İstanbul, Ekim 2002.

Avlonyalı Ekrem Bey, Osmanlı Arnavutluk’undan Anılar (1885-1912), çev. Atilla Dirim, İletişim Yay., 1. Baskı, İstanbul, 2006. 
Avlonyalı Süreyya Bey, Osmanlı Sonrası Arnavutluk (1912-1920), Yay. haz. Abdulhamit K1rmız1, Klasik Yay., İstanbul, 2009.

Aydın, Mithat, “Arnavutluk'un Osmanlı Devleti'nden Kopuşu Sorunu (1912-1913)”, Belgi Dergisi, C. 2, S. 17 (Kış 2019/I), s. 1094-1128.

Bello, Hasan, Osmanlı ve Arnavut Kaynaklarına Göre Arnavutluk’ta 1911 Malisörler İsyanı, Mimar Sinan Güzel Sanatlar Üniversitesi Sosyal Bilimler Enstitüsü, Yayımlanmamış Yüksek Lisans Tezi, İstanbul, 2009.

Birinci Frrka Erkân-1 Harbi Mehmet Nuri (Conker), Zâbit ve Kumandan, (Zabit ve Kumandan ile Hasb-1 Hâl'in içerisinde), Yay. haz. Ahmet Tetik, vd., Genelkurmay ATASE Yay., Ankara, 2010 .

Birecikli, İhsan Burak, “Avlonyalı İsmail Kemal Bey’in Bağımsılık Mücadelesi 1912- 1914”, Journal of History School, 41 (2019), ss. 592-620.

Birecikli, İhsan Burak, Arnavutlar ve Arnavutluk Sorunu 1908-1914, Gazi Üniversitesi Sosyal Bilimler Enstitüsü, Yayımlanmamış Doktora Tezi, Ankara, 2010.

Blumi, Isa, Reinstating the Ottomans, Palgrave Macmillan, 1st Published, New York, 2011.

Csaplár-Degovics, Krisztián, “The Policy of the Qemali Government Between December 1912 and April 1913”, In: ANNUARIO - Albanian Yearbook for historical and anthropological studies / Vjetari shqiptar për studimet historike dhe antropologjike. Tirana 2014, pp. 1-19.

Çakmak, Fevzi, Batı Rumeli’yi Nasıl Kaybettik?, Yay. haz. Ahmet Tetik, Türkiye İş Bankası Kültür Yay., 2. Bask1, İstanbul, 2012.

Çelebi, Mevlüt, “Rumeli’ye Veda Ederken Sultan Reşad'ın Kosova’yı Ziyareti”, Yeni Türkiye, S. 68 (Mart-Haziran 2015), Balkanlar Özel Sayıs1 III, ss. 3291-3298.

Çelik, Bilgin, “Geleneksel Yapı ile Modernite Arasındaki Gerilime Bir Örnek: Arnavutluk’ta Kan Davaları ve II. Meşrutiyet Döneminde Soruna Çözüm Arayışları”, Studies of the Ottoman Domain, C. 4, S. 7 (Ağustos 2014), ss. 18-41.

Dikici, Ali, “Osmanlı Makedonya'sında Kurulan İlk Uluslararası Polis Barış Koruma Misyonu: Mürzsteg Reform Programı”, Karadeniz Araştırmaları, C: 6, S. 24 (Kış 2010), ss. 75-108.

Elsie, Robert, "Boletini, İsa Bey (15 January 1864-23 January 1916)”, Historical Dictionary of Kosovo, The Scarecrow Press, 2nd Edition, Lanham, 2011, p. 48.

Gawrych, George, The Crescent and the Eagle: Ottoman Rule, Islam and the Albanians, 18741913, I.B. Tauris, New York, 2006.

Hayta, Necdet, Balkan Savaşları'nın Diplomatik Boyutu ve Londra Büyükelçiler Konferansı (17 Aralık 1912 - 11 Ağustos 1913), AKDTYK Atatürk Araştırma Merkezi Yay., Ankara, 2008.

Herbert, Aubery, Ben Kendim Osmanlı Ülkesine Son Seyahat, çev. Yılmaz Tezkan, 21. Yüzyıl Yay., Ankara, 1999.

Jacques, Edwin E., The Albanians: An Ethnic History from Prehistoric Times to the Present, McFarland \& Co., Jefferson, N.C., 1995.

Kansu, Aykut, 1908 Devrimi, çev. Ayda Erbal, İletişim Yay., 6. Bask1, İstanbul, 2011.

Kutlu, Sacit, Milliyetçilik ve Emperyalizm Yüzyılında Balkanlar ve Osmanlı Devleti, İstanbul Bilgi Üniversitesi Yay., 2. Bask1, İstanbul, 2018.

Külçe, Süleyman, Balkan Harbi’nde İhmal Faciaları, Yay. haz. Ercan Haytaoğlu, Çizgi Kitabevi Yay., Konya 2018.

Külçe, Süleyman, Firzovik Toplantısı ve Meşrutiyet, Yay. haz. İsmail Dervişoğlu, İsmail Küçükkılınç, Kitabevi Yay., 1. Baskı, İstanbul, 2013. 
Külçe, Süleyman, Osmanlı Tarihinde Arnavutluk, Yeni Asır Matbaası, İzmir, 1944.

Lütfi Simavi, Son Osmanlı Sarayında Gördüklerim, Yay. haz. Sami Kara, Nurer Uğurlu, Örgün Yay., 2. Bask1, İstanbul, 2004.

Malcolm, Noel, Kosova Balkanları Anlamak İçin, çev. Özden Arıkan, 1. Baskı, Sabah Kitapları, İstanbul, Mart 1999.

Mustafa Ragıb, Meşrutiyet'ten Önce Manastır'da Patlayan Tabanca, Yay. haz. Rahşan Aktaş, 1. Bask1, Bengi Yayınları, İstanbul, 2007.

Müfid Şemsi, El Hakku Ya'lû Velâ Yu'lâ Aleyh (Şemsi Paşa, Arnavudluk, İttihad ve Terakki), Yay. haz. Ahmed Nezih Galitekin, Şehir Yay, 2. Baskı, İstanbul, 2007.

Olgun, Said, “Avusturya-Macaristan İmparatorluğu Konsoloslarının Arnavutluk Coğrafyasındaki "Muzır Faaliyetlerine” Bazı Örnekler", Uluslararası Sosyal Araştırmalar Dergisi, C. 10, S. 50 (Haziran 2017), ss. 245-255.

Olgun, Said, Arnavut Milliyetçiliğinin Gelişiminde Mektepler, Gece Kitaplı̆̆ı, Ankara, 2016.

Osman Nuri, Abdülhamid-i Sâni ve Devr-i Saltanatı, Yay. haz. Osman Selim Kocahanoğlu, Temel Yay., İstanbul, 2017.

Özbozdağlı, Özer, “Osmanlı Hükümetinin Kosova Arnavutları Arasındaki Kan Davalarına Çözüm Bulma Çabaları 1908-1912”, Belleten, C. LXXXII, S. 295 (Aralık 2018), ss. 979-1011.

Sayg1l, Hasip, “Sultan II. Abdülhamid'in Meşruiyet Krizi: 1903 'te Mitroviçe'de İlk Rus Konsolosu Grigori Şerbina'nın Öldürülmesi”, Hacettepe Üniversitesi Türkiyat Araştırmaları, S. 20 (Bahar 2014), ss. 163-192.

Tahsin Paşa, Yıldız Hatıraları, Yay. haz. Ahmet Zeki İzgöer, İz Yayıncılık, 3. Baskı, İstanbul, 2018.

Tokay, Gül, Makedonya Sorunu Jön Türk İhtilalinin Kökenleri (1903-1908), Afa Yay., İstanbul, 1995.

Troçki, Lev, Balkan Savaşları, çev. Tansel Güney, Türkiye İş Bankası Kültür Yay., 1. Baskı, İstanbul, 2012.

Tunaya, Tarık Zafer, Türkiye'de Siyasal Partiler, C. I (İkinci Meşrutiyet Dönemi), İletişim Yay., 1. Baskı, İstanbul, 1998.

Uşaklıgil, Halid Ziya, Saray ve Ötesi, Yay. haz. Nur Özmel Akın, Özgür Yay., İstanbul, 2003.

Ünlü, Mucize, Kosova Vilayeti, Gece Kitaplığı, Ankara, 2014.

Warrander, Gail; Knaus, Verena, Kosova, Bradt Travel Guides Ltd, 1st Edition, Buckinghamshire, 2007.

Yarc1, Güler, "Kosova'nın Hüzünlü Yüzü: Paylaş1lamayan Şehir "Mitroviçe’”, Bozkırdan Batıya (Prof. Dr. Hüseyin Salman'a Armağan), ed. Güler Yarc1, Epilson Yayınevi, 1. Baskı, İstanbul, 2017, ss. 373-427.

Yiğit, Yücel, "Milliyetçilik Çağında Prizren İttihat Cemiyeti”, Turkish Studies, Vol. 4/8, Fall 2009 , ss. 2462-2491.

Zürcher, Erik J., Osmanlı İmparatorluğu’ndan Atatürk Türkiye'sine Bir Ulusun İnşası Jön Türk Mirası, çev. Lütfi Yalçın, Akılçelen Kitaplar Yay., 1. Baskı, Ankara, 2015. 